NATALIE MATOS SILVA

\title{
AS CLÁUSULAS DE TAX SPARING E MATCHING CREDIT NOS ACORDOS DE BITRIBUTAÇÃO
}

\author{
DISSERTAÇÃO DE MESTRADO \\ Orientador: Professor Titular Luís Eduardo Schoueri
}

Faculdade de Direito da USP

SÃO PAULO

2013 
NATALIE MATOS SILVA

\title{
AS CLÁUSULAS DE TAX SPARING E MATCHING CREDIT NOS ACORDOS DE BITRIBUTAÇÃO
}

\begin{abstract}
Dissertação realizada sob a orientação do Professor Titular Luís Eduardo Schoueri, apresentada à Faculdade de Direito da Universidade de São Paulo como requisito para conclusão do Mestrado em Direito Econômico, Financeiro e Tributário.
\end{abstract}

Faculdade de Direito da USP

SÃO PAULO

2013 
BANCA EXAMINADORA 


\section{DEDICATÓRIA}

Aos meus pais, Rosângela e Leônidas, pelo carinho e compreensão constantes.

A Carla, pela amizade que torna os meus dias mais felizes.

A João Victor, pela parceria de vida, pelo exemplo de dedicação e pelo incondicional apoio. 


\section{AGRADECIMENTOS}

Ao Professor Luís Eduardo Schoueri, não somente pela inestimável oportunidade que me concedeu, de ser sua orientanda no Programa de Pós-Graduação da minha querida Faculdade de Direito do Largo de São Francisco, mas principalmente pelos anos de convivência e ensinamentos, que tanto acrescentaram ao que me tornei - como acadêmica, como profissional e como pessoa.

Aos meus pais, irmã e demais familiares, pelo apoio nas horas mais preciosas, pelo carinho que me deram (e dão) e pelo colo que sempre colocaram à minha disposição quando foi preciso.

A João Victor, noivo e amigo, pela incansável disposição em me ajudar no que necessário fosse: com palavras de ânimo e carinho, debatendo as minhas dúvidas e inquietações, revisando o texto e acreditando mais em mim do que eu mesma seria capaz.

A Noemia, pela amizade e pelo zelo com que sempre me tratou, que tornaram mais amena essa difícil caminhada.

Aos amigos que estiveram ao meu lado, pela inspiração que representam em minha vida. 
Segue o teu destino,

Rega as tuas plantas,

Ama as tuas rosas.

O resto é a sombra

De árvores alheias.

(Ricardo Reis, heterônimo de Fernando Pessoa) 


\title{
RESUMO
}

Este estudo tem por escopo analisar o conceito das cláusulas de tax sparing e matching credit, os principais argumentos favoráveis e contrários à utilização desses mecanismos e as hipóteses em que tais cláusulas são adotadas, nos âmbitos nacional e internacional.

Sabe-se que, em um primeiro momento, a Organização para a Cooperação e Desenvolvimento Econômico (“OCDE”) chegou a recomendar a utilização das cláusulas de tax sparing nos acordos de bitributação celebrados entre países com graus diferentes de desenvolvimento econômico, como uma forma de atrair investimentos para os países menos desenvolvidos.

No entanto, em relatório publicado em 1998, denominado "Tax sparing: a reconsideration", a OCDE reviu sua posição inicial sobre o assunto, passando então a desencorajar o uso dessas cláusulas por seus países membros, através de diversas críticas e questionamentos acerca de sua adoção.

O Brasil, por sua vez, desde os primeiros acordos de bitributação celebrados, nos primórdios da década de 1960, tem firmado a política de sempre negociar cláusulas de tax sparing e matching credit, especialmente nos acordos celebrados com países desenvolvidos.

Considerando-se tal cenário, pretende-se, com o presente trabalho, estudar as cláusulas de tax sparing e matching credit de forma profunda, de modo a oferecer subsídios para um adequado enfrentamento da questão em futuras negociações de acordos de bitributação pelo País.

\author{
Palavras-chave: Cláusulas de Tax Sparing \\ Cláusulas de Matching Credit \\ Acordos de Bitributação \\ Fonte \\ Residência \\ Incentivos Fiscais
}




\begin{abstract}
The purpose of this study is to analyze the concept of tax sparing and matching credit clauses, the main arguments for and against the use of these mechanisms and the circumstances in which such clauses are adopted, nationally and internationally.

It is known that, at first, the Organisation for Economic Co-operation and Development (“OECD”) used to recommend the inclusion of tax sparing clauses in double taxation conventions concluded between countries with different levels of economic development, as a way of attracting investments for less developed countries.
\end{abstract}

However, the OECD revised its initial position on the subject in a report published in 1998, called "Tax sparing: a reconsideration", discouraging the use of such clauses by its member countries through various criticisms and questions about their adoption.

In its turn, since the first double taxation agreements concluded in the early 1960s the Brazilian policy regarding the matter has always been to negotiate tax sparing and matching credit clauses, especially in conventions with developed countries.

Given such a scenario, this paper aims at studying tax sparing and matching credit clauses deeply, in order to provide devices for an accurate understanding of the issue in future negotiations of double taxation conventions by the Country.

Keywords: $\quad$ Tax Sparing Clauses

Matching Credit Clauses

Double Taxation Conventions

Source

Residence

Tax Incentives 


\section{SUMÁRIO}

I. INTRODUÇÃO. 10

\section{FUNDAMENTO E CONCEITO DAS CLÁUSULAS DE TAX SPARING E MATCHING CREDIT

2.1. Breves considerações sobre a bitributação internacional da renda e os métodos para eliminá-la ou mitigá-la.....

2.1.1. Os acordos de bitributação

2.2. Limitações do método do crédito e o surgimento das cláusulas de tax sparing e

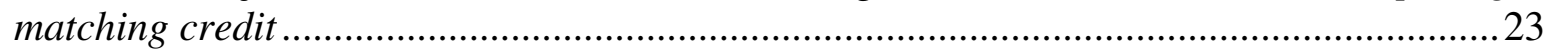

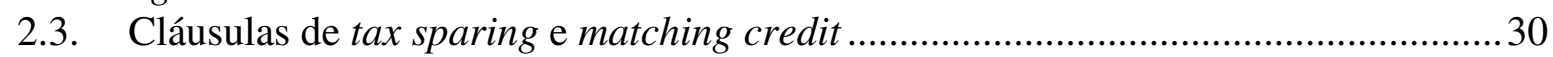

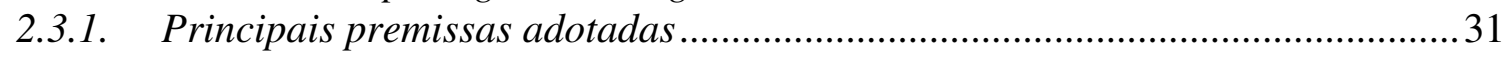

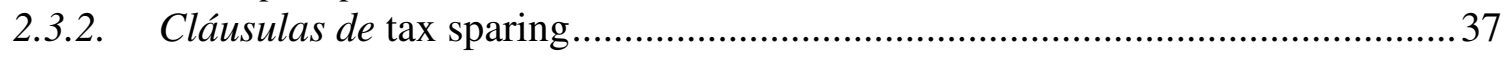

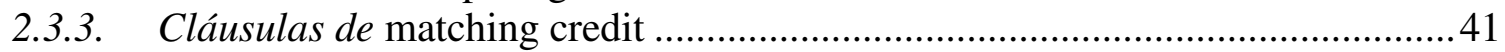

2.3.4. Tax sparing $e$ matching credit: semelhanças e diferenças ................................. 45

2.3.5. Histórico das cláusulas de tax sparing $e$ matching credit ...................................46

2.4. Interpretação das cláusulas de tax sparing e matching credit ................................... 49

2.4.1. Considerações gerais sobre a interpretação dos acordos de bitributação.........49

2.4.2. Interpretação das cláusulas de tax sparing $e$ matching credit ............................55

III. A POSIÇÃO DA ONU E DA OCDE A RESPEITO DAS CLÁUSULAS DE TAX

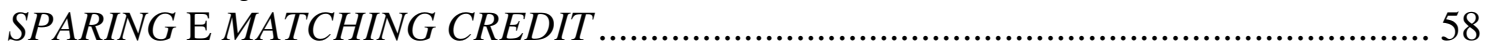

3.1. A posição da OCDE a respeito das cláusulas de tax sparing ....................................58

3.1.1. As cláusulas de tax sparing nos Comentários à Convenção Modelo da OCDE 58

3.1.2. Críticas da OCDE à adoção das cláusulas de tax sparing: relatório "Tax

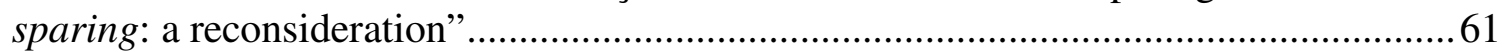

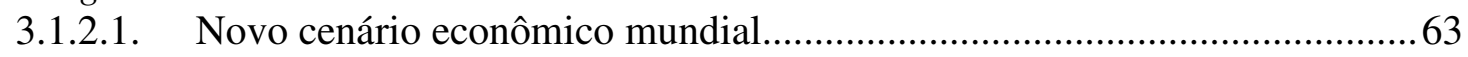

3.1.2.2. Tax sparing como instrumento de auxílio aos países em desenvolvimento65

3.1.2.3. Tax sparing pode encorajar uma excessiva repatriação dos lucros.............66

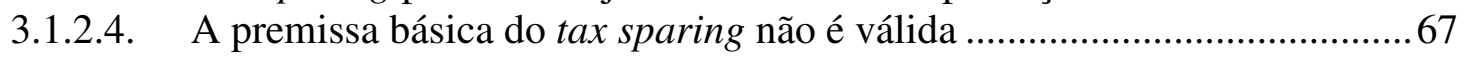

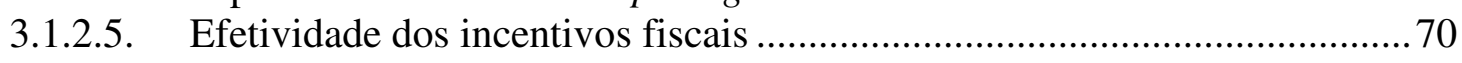

3.1.2.6. Cláusulas de tax sparing dão margem a práticas abusivas........................... 71

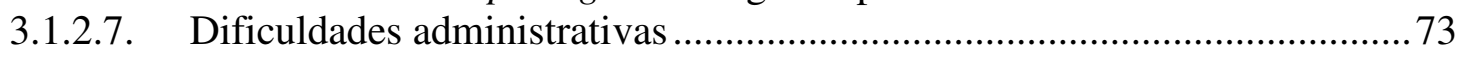

3.1.3. Boas práticas na elaboração de cláusulas de tax sparing..................................74

3.1.4. Recomendações da OCDE relativas à adoção de cláusulas de tax sparing pelos

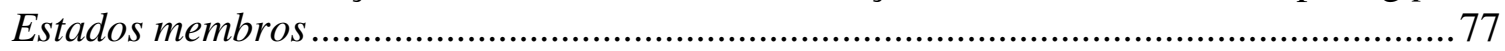

3.2. As cláusulas de tax sparing e matching credit na Convenção Modelo da ONU.......78

\section{AS CLÁUSULAS DE TAX SPARING E MATCHING CREDIT NOS DEMAIS PÁISES} 81

4.1. A posição norte-americana a respeito das cláusulas de tax sparing....

4.1.1. Histórico da posição norte-americana a respeito das cláusulas de tax sparing 81

4.1.2. Objeções dos Estados Unidos à adoção de cláusulas de tax sparing .................87

4.1.3. O acordo de bitributação entre Brasil e Estados Unidos ................................... 92

4.2. A acolhida internacional das cláusulas de tax sparing e matching credit ................. 95

4.2.1. As cláusulas de tax sparing e matching credit em países desenvolvidos............ 97

4.2.2. As cláusulas de tax sparing e matching credit em países em desenvolvimento 100 
V. OS ACORDOS DE BITRIBUTAÇÃO BRASILEIROS E AS CLÁUSULAS DE TAX SPARING E MATCHING CREDIT.

5.1. A posição brasileira a respeito das cláusulas de tax sparing e matching credit ...... 104

5.2. Histórico das cláusulas de tax sparing e maching credit nos acordos de bitributação

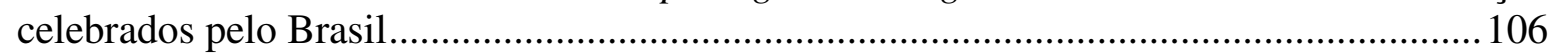

5.3. Análise das cláusulas de tax sparing previstas nos acordos de bitributação celebrados pelo Brasil.

5.3.1. Acordo Brasil-Japão 111

5.3.2. Acordo Brasil-Bélgica 112

5.4. Análise das cláusulas unilaterais de matching credit previstas nos acordos de

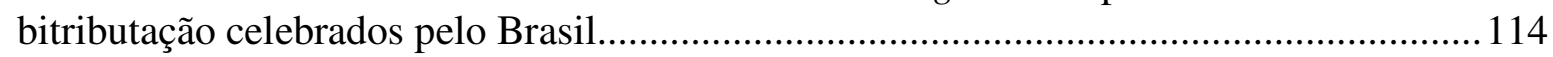

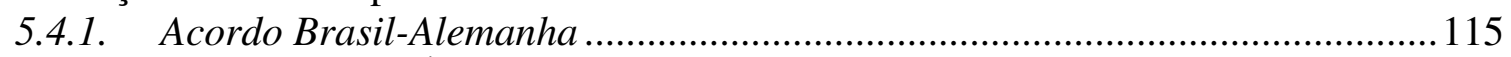

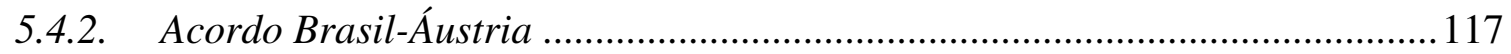

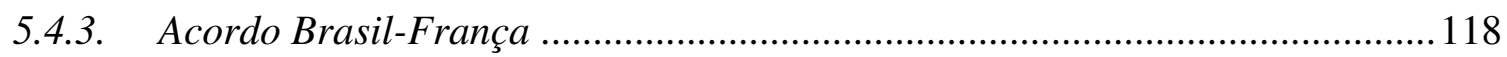

5.5. Análise das cláusulas recíprocas de matching credit previstas nos acordos de bitributação celebrados pelo Brasil............................................................................. 124

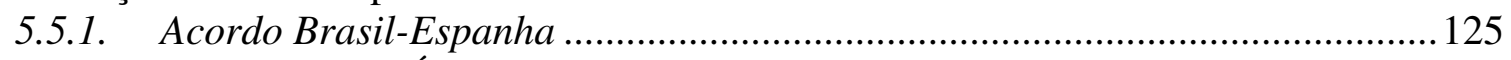

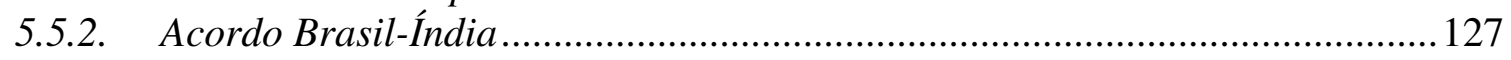

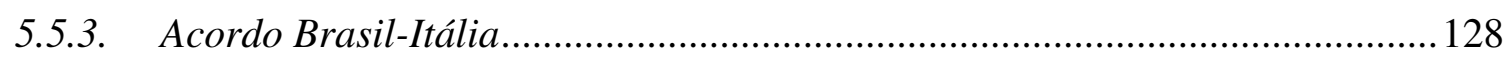

VI. CLÁUSULAS DE TAX SPARING E MATCHING CREDIT: INDEVIDO AUXÍLIO AOS PAÍSES EM DESENVOLVIMENTO OU RECONHECIMENTO DA COMPETÊNCIA DO ESTADO DA FONTE? ........................................................................... 130

6.1. A visão tradicional a respeito das cláusulas de tax sparing e matching credit........130

6.2. Uma nova visão para as cláusulas de tax sparing e matching credit.......................131

6.3. Perspectivas para o futuro das cláusulas de tax sparing e matching credit .............. 134

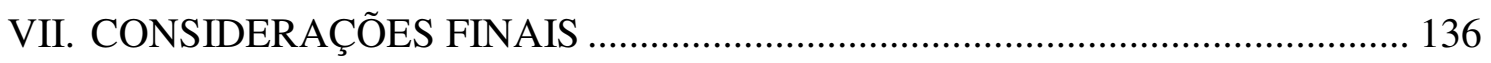

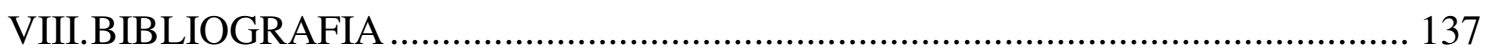




\section{INTRODUÇÃO}

Na disciplina dos acordos celebrados para evitar a dupla tributação internacional sobre a renda (que também serão referidos no presente trabalho, simplesmente, como "acordos de bitributação"), destacada relevância vêm assumindo as cláusulas de tax sparing e matching credit.

De um modo geral, nos acordos de bitributação que preveem o método do crédito como instrumento para mitigar ou mesmo eliminar a dupla tributação (ou "bitributação"), considera-se como montante passível de ser compensado com o imposto devido no Estado da residência, o imposto efetivamente pago no Estado da fonte.

No entanto, nas negociações de acordos entre países desenvolvidos e países em desenvolvimento, foram criadas as cláusulas de tax sparing e matching credit, que são modalidades extraordinárias de crédito de imposto desvinculadas do montante que foi pago no Estado da fonte.

Tais modalidades de crédito surgiram com o fito de fazer com que a renúncia fiscal suportada pelos países em desenvolvimento pudesse de fato ser revertida em benefício para o investidor não residente, e não para o Estado da residência deste, situação que ocorre com a aplicação do método do crédito tradicional.

Nesse sentido, em linhas gerais pode-se dizer que o tax sparing é um crédito que corresponde ao imposto que teria sido pago no Estado da fonte, na ausência de benefícios fiscais com o intuito de incentivar o investimento estrangeiro em tal Estado. Pretende-se, no tax sparing, que os incentivos fiscais concedidos pelo Estado da fonte sejam efetivamente fruídos pelo investidor, e não pelo Estado da residência.

Já o matching credit independe da existência de um incentivo fiscal no Estado da fonte. O Estado da residência concorda, no texto do próprio acordo de bitributação, em conceder um crédito (geralmente) superior à alíquota máxima que pode ser aplicada pelo Estado da fonte, nos termos do próprio acordo.

Sabe-se que, em um primeiro momento, a Organização para a Cooperação e Desenvolvimento Econômico ("OCDE”) chegou a recomendar a utilização de tais 
cláusulas nos acordos de bitributação celebrados entre países com graus diferentes de desenvolvimento, como uma forma de atrair investimentos para os países menos desenvolvidos.

No entanto, em relatório publicado em 1998, denominado "Tax sparing: a reconsideration", a OCDE reviu sua posição inicial sobre o assunto, passando então a desencorajar o uso dessas cláusulas por seus Estados membros, através de diversas críticas e questionamentos acerca de sua adoção.

A utilidade do mecanismo foi então colocada em jogo, uma vez que, na visão da OCDE, entre outras coisas, o tax sparing pode favorecer a ocorrência de situações de planejamento tributário abusivo e de evasão fiscal, bem como não seria um instrumento eficiente para garantir o desenvolvimento econômico dos Estados da fonte.

A Organização questionou, ainda, o fato de que muitos países que não eram desenvolvidos nas décadas de 1960 e de 1970, quando diversos acordos foram negociados, hoje apresentam economias tão desenvolvidas quanto, ou até mais do que, as economias de alguns de seus países membros.

O Brasil, por sua vez, desde os primeiros acordos de bitributação assinados, nos primórdios da década de 1960, tem firmado a política de sempre negociar cláusulas de tax sparing e matching credit, especialmente nos acordos celebrados com países desenvolvidos.

É de se notar, inclusive, que os primeiros parceiros brasileiros em acordos de bitributação, Suécia e Japão, já haviam assinado acordos, anteriormente à celebração do acordo com o Brasil, que continham cláusulas de tax sparing e matching credit. Isso parece explicar a escolha, pelo Brasil, de tais países para negociar seus primeiros acordos de bitributação.

Nos dias de hoje, a política brasileira de sempre adotar cláusulas de tax sparing e matching credit em seus acordos com países desenvolvidos certamente é revestida de polêmica que não a acompanhava quando da assinatura dos acordos de bitributação com Suécia e Japão.

\footnotetext{
${ }^{1}$ Cf. ORGANIZAÇÃO PARA A COOPERAÇÃO E DESENVOLVIMENTO ECONÔMICO. Tax sparing: a reconsideration. Paris: OCDE, 1998.
} 
Deve-se mencionar, nesse sentido, que a cláusula de matching credit foi um dos motivos cruciais para a denúncia do acordo de bitributação firmado entre Brasil e Alemanha. Da mesma forma, o tax sparing é a principal razão do impasse nas negociações de um acordo entre Brasil e Estados Unidos, uma vez que a política tributária norteamericana rechaça a inclusão de cláusulas desse tipo nos acordos celebrados por aquele país, ao mesmo tempo em que o Brasil veementemente recusa-se a deixar de adotar a referida cláusula em um acordo de bitributação com um país desenvolvido.

De fato, um ponto que pode ser levantado pelos parceiros brasileiros contra a inclusão do tax sparing e do matching credit nos acordos que vierem a ser celebrados doravante é justamente o nível de desenvolvimento econômico do Brasil, que atualmente teria muito menos necessidade de receber incentivos aos investimentos do que ocorria nas décadas de 1960 e de 1970.

Diante desse panorama, a presente dissertação não tratará da suposta desnecessidade de cláusulas de tax sparing e matching credit em face do atual nível de desenvolvimento econômico do Brasil, o qual ocupa, ao menos sob o ponto de vista estritamente econômico, posição de destaque, na frente de diversos Estados membros da OCDE (muitos dos quais se encontram em penosa situação de crise econômica).

Da mesma forma, não se pretende analisar de forma profunda a efetividade da adoção de cláusulas de tax sparing e matching credit na promoção de investimentos em países menos desenvolvidos.

Tais discussões, trazidas à tona pela OCDE, certamente são bastante relevantes, mas que não poderão ser travadas sem que se tenha em mãos uma ampla gama de dados estatísticos, relativos às economias de diversos países, que sejam aptos a fundamentar qualquer alegação que se pretenda fazer no tocante a estes assuntos, seja favorável ou contrariamente às cláusulas de tax sparing e matching credit.

Por essa razão, tais questões fogem do propósito da presente dissertação, que, ao contrário, pretende analisar juridicamente as cláusulas de tax sparing e matching credit, deixando-se de lado questões relativas à viabilidade, efetividade ou mesmo necessidade de sua utilização. 
Uma vez delimitado o escopo da presente dissertação, passa-se então ao relato dos temas que serão tratados nas próximas páginas.

Inicialmente, buscar-se-á identificar o contexto em que surgem as cláusulas de tax sparing e matching credit. Desta feita, o conceito de dupla tributação jurídica da renda e as principais medidas, unilaterais e bilaterais, destinadas à sua mitigação ou eliminação, serão objeto de breve análise na presente dissertação.

A partir do estudo do método do crédito previsto nos acordos de bitributação e de seus efeitos na hipótese de concessão de incentivos fiscais pelo Estado da fonte, será possível verificar em que medida faz-se necessária a inclusão de cláusulas de tax sparing e matching credit nos instrumentos celebrados entre países que se encontram em diferentes graus de desenvolvimento econômico.

Após este primeiro momento, buscar-se-á diferenciar os conceitos de tax sparing e matching credit, sobretudo sob o ponto de vista da doutrina, tanto brasileira quanto estrangeira. Nesse passo, será possível verificar que a correta delimitação de ambos os conceitos é fundamental, sobretudo considerando-se os resultados que podem advir de diversas classificações atribuídas às mencionadas cláusulas. Ainda neste mesmo capítulo, serão tecidos alguns comentários sobre a interpretação das cláusulas de tax sparing e matching credit, no contexto da interpretação dos acordos de bitributação.

Ademais, a posição da OCDE no tocante ao tema será estudada, avaliando-se cada um dos argumentos contrários ao tax sparing levantados pela Organização, com vistas a analisar a validade de tais questionamentos, especialmente sob a perspectiva brasileira. Dito de outra forma, buscar-se-á verificar se as críticas da OCDE poderiam servir de fundamento a uma revisão da política brasileira de negociação de acordos de bitributação, com o abandono, pelo Brasil, das cláusulas de tax sparing e matching credit.

Além do entendimento da OCDE acerca da matéria, pretende-se também examinar qual é a posição da Organização das Nações Unidas (“ONU”), dos Estados Unidos da América e de outros países, desenvolvidos ou em desenvolvimento, a respeito da utilização das referidas cláusulas. Será possível, desta forma, verificar qual é a acolhida internacional atual do tema, na doutrina e na jurisprudência, determinando-se quais são os principais argumentos adotados, sejam contrários ou favoráveis, quando se trata do assunto em questão. 
Posteriormente, pretende-se analisar com detalhes a política brasileira de negociação de acordos de bitributação no que tange à adoção das cláusulas de tax sparing e matching credit, a fim de identificar os principais parceiros, a evolução e a importância da utilização de ambos pelo Brasil na atração de investimentos estrangeiros.

Por fim, utilizar-se-á o substrato adquirido com os capítulos anteriores como instrumento para que se possa concluir, com clareza, qual é a verdadeira função de que se revestem as cláusulas de tax sparing e matching credit, normalmente classificadas como disposições normativas de auxílio dos países desenvolvidos aos países em desenvolvimento. Conforme se notará, existem outras variáveis a serem consideradas no estudo desta temática, de modo que será possível apresentar conclusões que se distanciam do senso comum geralmente invocado quando se está diante desta matéria. 


\section{FUNDAMENTO E CONCEITO DAS CLÁUSULAS DE TAX SPARING E MATCHING CREDIT}

\subsection{Breves considerações sobre a bitributação internacional da renda e os métodos para eliminá-la ou mitigá-la}

A coexistência dos critérios de tributação pela fonte e pela residência, bem como dos princípios da territorialidade e da tributação em bases universais ${ }^{2}$, acaba conduzindo a situações de dupla tributação internacional da renda (ou simplesmente "bitributação"), a qual pode ser dividida em duas categorias, quais sejam, bitributação jurídica e bitributação econômica ${ }^{3}$.

Tem-se a bitributação jurídica quando forem exigidos, por mais de um Estado, impostos idênticos ou comparáveis, do mesmo contribuinte, em relação ao mesmo objeto tributável e ao mesmo período ${ }^{4-5}$.

A bitributação jurídica pode se originar, por exemplo, pelo fato de dois países conceituarem o termo "residente" de maneiras diferentes, ou mesmo de conflitos envolvendo a tributação baseada na residência e a tributação baseada na fonte. Podem-se ser mencionados, nesse sentido, os seguintes tipos de conflitos como tendentes a gerar situações de bitributação jurídica ${ }^{6}$ :

\footnotetext{
${ }^{2}$ Sobre o assunto, cf. Luís Eduardo Schoueri. "Princípios no Direito Tributário Internacional: territorialidade, fonte e universalidade". FERRAZ, Roberto (org.). Princípios e limites da tributação. São Paulo: Quartier Latin, 2005, pp. 321-374.

${ }^{3}$ Note-se que, para alguns doutrinadores, é incorreta a classificação da dupla tributação internacional entre jurídica e econômica, por entenderem que bitributação internacional somente pode ser jurídica, haja vista que o caráter econômico é pressuposto do próprio conceito de tributação. Cf., nesse sentido: Heleno Taveira Torres. Pluritributação internacional sobre as rendas de empresas. 2. ed. São Paulo: Revista dos Tribunais, 2001, pp. 406-407; Livia Leite Baron Gonzaga. A interpretação das convenções contra dupla tributação internacional à luz da teoria da argumentação jurídica. Tese de doutorado. São Paulo: Universidade de São Paulo, 2010, pp. 249-250. A despeito de tal posicionamento, no presente trabalho será adotada a classificação tradicional, dividindo-se a dupla tributação internacional em "econômica" e "jurídica".

${ }^{4}$ Cf. Gerd Willi Rothmann. "Bitributação internacional" (verbete). FRANÇA, Rubens Limongi (coord.). Enciclopédia Saraiva do Direito. v. 11. São Paulo: Saraiva, 1977, pp. 449-450.

${ }^{5}$ Trata-se da regra das quatro identidades, mencionada por Alberto Xavier: (i) identidade do objeto; (ii) identidade do sujeito; (iii) identidade do período tributário; e (iv) identidade do imposto. Cf. Alberto Xavier. Direito tributário internacional do Brasil. 6. ed. Rio de Janeiro: Forense, 2007, p. 33.

${ }^{6}$ Cf. Chris Finnerty et al. Fundamentals of international tax planning. Amsterdam: IBFD, 2007, pp. 8-9.
} 
(i) Conflito residência-residência: ocorre quando mais de um Estado sujeita uma mesma pessoa à tributação sobre sua renda mundial;

(ii) Conflito fonte-fonte: ocorre quando mais de um Estado sujeita uma mesma pessoa, que não é residente de nenhum deles, à tributação, em razão de rendimentos que são considerados como auferidos no território de ambos;

(iii) Conflito residência-fonte: ocorre quando uma pessoa é residente de um Estado e aufere rendimentos de outro Estado, sendo que ambos os Estados tributam tal rendimento.

Já a bitributação econômica surge na hipótese em que um mesmo rendimento é tributado mais de uma vez, em poder de contribuintes diferentes. O principal exemplo de bitributação econômica consiste na tributação dos lucros empresariais, que se sujeitam à imposição tributária no nível da pessoa jurídica, quando são apurados, e no nível dos sócios ou acionistas, quando são distribuídos.

Para fins do presente trabalho, interessa analisar a bitributação jurídica da renda. Embora não exista uma regra de direito internacional público que proíba a bitributação, há certo consenso de que esta é nociva às trocas de bens e serviços e fluxos de investimentos e, por isso, deve ser evitada ${ }^{7}$. Considerando-se tal cenário, foram desenvolvidos mecanismos unilaterais e bilaterais para mitigá-la ou eliminá-la.

Conforme menciona Gerd Willi Rothmann, para evitar a dupla tributação, os Estados podem limitar sua soberania fiscal através das seguintes medidas ${ }^{8}$ :

(i) Medidas autônomas internas, unilaterais ou condicionadas à reciprocidade, que têm por objeto a delimitação da soberania fiscal do Estado com relação ao exterior; e

(ii) Acordos para evitar a bitributação internacional, ou acordos comerciais e outros acordos internacionais.

Não havendo um acordo de bitributação entre dois Estados, os rendimentos auferidos em um Estado por um residente de outro Estado estarão, em princípio, sujeitos à

\footnotetext{
${ }^{7}$ Cf. Gerd Willi Rothmann, op. cit. (nota 4), p. 452.

${ }^{8}$ Cf. Gerd Willi Rothmann, op. cit. (nota 4), p. 449.
} 
tributação em ambos os Estados ${ }^{9}$. Para evitar essa situação, os Estados passam a prever, em sua legislação interna, medidas unilaterais para eliminar ou reduzir a dupla tributação internacional $^{10}$.

Ao conceder medidas unilaterais contra a dupla tributação em âmbito interno, os Estados geralmente adotam como princípio a neutralidade de exportação de capitais (capital export neutrality ou "CEN") ou a neutralidade de importação de capitais (capital import neutrality ou "CIN"), conceitos inicialmente desenvolvidos por Richard A. Musgrave, em texto publicado em $1960^{11}$.

Pelo princípio da neutralidade de exportação de capitais, a neutralidade é analisada do ponto de vista do Estado da residência do investidor: os investidores devem estar sujeitos ao mesmo nível de tributação independentemente do país em que os rendimentos são auferidos ${ }^{12}$.

De acordo com o princípio da neutralidade de importação de capitais, a neutralidade é entendida sob a perspectiva do Estado receptor dos investimentos, i.e., o Estado da fonte: os investimentos realizados dentro de um país devem estar sujeitos ao mesmo nível de tributação, sejam efetivados por investidores nacionais ou por investidores estrangeiros ${ }^{13}$.

Os Estados que adotam a neutralidade de exportação de capitais utilizam o método do crédito para evitar a dupla tributação, enquanto aqueles que seguem o princípio da neutralidade de importação de capitais aplicam o método da isenção ${ }^{14}$. Tais métodos serão estudados com maiores detalhes ao longo do presente trabalho.

\footnotetext{
9 João Victor Guedes Santos e Flávia Cavalcanti Nogueira Rodrigues, analisando as medidas unilaterais adotadas por diversos países, concluem que os acordos de bitributação não oferecem grau de proteção significativamente maior do que a adoção dos referidos mecanismos unilaterais, na medida em que os tratados, de modo geral, apenas reproduzem os dispositivos para prevenir a dupla tributação que já estão previstos na legislação interna. Cf. João Victor Guedes Santos e Flávia Cavalcanti Nogueira Rodrigues. "Compensação do imposto pago no exterior: a aplicabilidade de medidas unilaterais em casos de inobservância de limitações contidas em tratado". Revista de Direito Tributário Internacional. v. 10. São Paulo: Quartier Latin, 2009, p. 89.

${ }^{10}$ Cf. Gerd Willi Rothmann, op. cit. (nota 4), p. 449.

${ }^{11}$ Cf. Richard A. Musgrave. "Criteria for foreign tax credit". Taxation and operations abroad. Princeton: Tax Institute, 1960, pp. 83-93.

${ }^{12}$ Cf. Richard A. Musgrave, op. cit. (nota 11), p. 79.

${ }^{13}$ Cf. Richard A. Musgrave, op. cit. (nota 11), pp. 85-86; IBFD. IBFD International Tax Glossary. 6. ed. Amsterdam: IBFD, 2009, p. 61; Wolfgang. Schön. "International tax coordination for a second-best world (part I)". World Tax Journal. v. 1, outubro, 2009, p. 79.

${ }^{14}$ Cf. Chris Finnerty et al., op. cit. (nota 6), p. 9.
} 
Além do método do crédito e do método da isenção, que são os mais conhecidos e utilizados, alguns Estados aplicam outros mecanismos para evitar a dupla tributação unilateralmente, baseando-se em outro princípio de neutralidade.

Com efeito, pelo princípio da neutralidade nacional (national neutrality ou "NN"), entende-se que os investimentos no exterior não devem ser incentivados, tampouco impedidos ${ }^{15}$. Um exemplo da aplicação do princípio da neutralidade nacional é o método da dedução dos impostos pagos no exterior, que consiste na dedutibilidade dos impostos estrangeiros da base de cálculo do imposto calculado internamente ${ }^{16}$.

Tal método, como aponta Gerd Willi Rothmann, não constitui medida capaz de eliminar a dupla tributação, mas considera o imposto pago no exterior como despesa dedutível $^{17}$.

\subsubsection{Os acordos de bitributação}

Além das medidas unilaterais, os Estados também limitam sua soberania fiscal ao negociar acordos internacionais em matéria tributária. Os acordos de bitributação são, assim, instrumentos utilizados pelos Estados, com vistas a mitigar ou impedir a bitributação internacional em matéria de imposto sobre a renda, o que se dá por meio de concessões mútuas, em que ambos os Estados contratantes renunciam a uma parcela de sua pretensão tributária ${ }^{18}$.

Os acordos de bitributação geralmente são elaborados com base em modelos, que apresentam estruturas semelhantes. Os modelos mais conhecidos e utilizados ${ }^{19}$ são o da OCDE ("Convenção Modelo da OCDE”) ${ }^{20}$ e o da ONU ("Convenção Modelo da ONU”)"

\footnotetext{
${ }^{15}$ Cf. IBFD, op. cit. (nota 13), p. 290.

${ }^{16}$ Cf. Wolfgang. Schön, op. cit. (nota 13), p. 83.

${ }^{17}$ Cf. Gerd Willi Rothmann, op. cit. (nota 4), p. 453.

${ }^{18}$ Cf. Luís Eduardo Schoueri. Preços de transferência no direito tributário brasileiro. 2. ed. São Paulo: Dialética, 2006, p. 260.

19 Além destes, convém destacar que os Estados Unidos e os países do Pacto Andino possuem modelos próprios de acordo de bitributação.

${ }^{20}$ A Convenção Modelo da OCDE teve sua primeira versão em 1963. Em 1977, foi publicada nova versão, que segue sendo constantemente atualizada, até hoje.

${ }^{21}$ A Convenção Modelo da ONU foi apresentada em 1980.
} 
A Convenção Modelo da OCDE tem como tendência privilegiar a tributação pelo Estado da residência, que como regra geral traduz países desenvolvidos, ao passo que a Convenção Modelo da ONU, embora em diversos aspectos seja muito semelhante à Convenção Modelo da OCDE, acaba por trazer medidas mais benéficas aos interesses dos países menos desenvolvidos, que normalmente figuram como fonte de rendimentos ${ }^{22}$.

Atualmente, tem-se discutido a real necessidade dos acordos de bitributação, uma vez que os países dispõem das já mencionadas medidas unilaterais para lidar com a questão da bitributação ${ }^{23}$. Não se pode negar, contudo, que a eliminação da dupla tributação é uma das principais funções de um acordo de bitributação, e que os acordos existentes servem a essa finalidade.

Conforme relata Roberto França de Vasconcellos, o fenômeno da bitributação acaba por distorcer a eficiência e a neutralidade dos sistemas jurídicos dos países envolvidos no comércio internacional, afetando de forma mais contundente os países em desenvolvimento, dependentes que são do capital internacional ${ }^{24}$.

No mesmo sentido, a OCDE menciona, na introdução aos Comentários à Convenção Modelo, que os efeitos nocivos da dupla tributação jurídica sobre as trocas de bens e serviços e sobre os movimentos de capital, tecnologia e pessoas são de tal forma conhecidos que é desnecessário apontar a importância da remoção dos obstáculos que a dupla tributação representa ao desenvolvimento das relações econômicas entre os Estados $^{25}$.

Sergio André Rocha destaca, entre as finalidades dos acordos contra a dupla tributação, a repartição das receitas tributárias entre os Estados contratantes ${ }^{26}$. Não nos parece ser este um objetivo autônomo dos acordos de bitributação, mas um meio através do qual se atinge o objetivo de eliminar a dupla tributação jurídica. Assim, como forma de

\footnotetext{
${ }^{22}$ Cf. Rodrigo Maitto da Silveira. Aplicação de tratados internacionais contra a bitributação - Qualificação de partnership joint ventures. Série Doutrina Tributária Vol. I. São Paulo: Quartier Latin, 2006, pp. 103-104; Roberto França de Vasconcellos. "Aspectos econômicos dos tratados internacionais em matéria tributária". Revista de Direito Tributário Internacional. v. 1. São Paulo: Quartier Latin, 2005, p. 163.

${ }^{23}$ Nesse sentido, Sergio André Rocha, baseado em lição de David R. Davies, lembra das diversas situações em que a bitributação pode ser evitada pela simples adoção das medidas unilaterais, de tal sorte que os acordos de bitributação tornam-se irrelevantes para a finalidade de evitar a dupla tributação (a qual não ocorreria, ainda que não houvesse acordo de bitributação). Cf. Sergio André Rocha. Interpretação dos tratados contra a bitributação da renda. Rio de Janeiro: Lumen Juris, 2008, p. 49.

${ }^{24}$ Cf. Roberto França de Vasconcellos, op. cit. (nota 22), p. 158.

${ }^{25} \mathrm{Cf}$. Comentários à Convenção Modelo da OCDE, Introdução, parágrafo $1^{\circ}$.

${ }^{26}$ Cf. Sergio André Rocha, op. cit. (nota 23), pp. 45-46.
} 
evitar a bitributação, os acordos atuam repartindo a competência tributária (e, como consequência, as receitas tributárias).

Além disso, os acordos de bitributação têm o papel de combater a evasão fiscal internacional $^{27}$, haja vista a previsão do intercâmbio de informações do artigo 26 da Convenção Modelo da OCDE e as diversas medidas antievasivas previstas nos modelos de acordos, cada vez com maior frequência.

A prevenção da aplicação de tratamentos discriminatórios também é entendida como um dos objetivos dos acordos de bitributação, embora a cláusula de não discriminação prevista no artigo 24 da Convenção Modelo da OCDE não seja suficientemente abrangente, aplicando-se somente na prevenção de discriminação por um Estado contratante com relação aos nacionais de outro Estado contratante, bem como com relação aos residentes de outro Estado contratante, em situações específicas ${ }^{28}$.

Por fim, há que se destacar que os acordos de bitributação possuem a finalidade de fomentar os investimentos e as relações comerciais entre os Estados contratantes ${ }^{29}$, através da proteção da segurança jurídica dos investidores estrangeiros ${ }^{30}$, sendo essa uma das mais relevantes funções de tais instrumentos no desenvolvimento da economia mundial.

Verificadas as funções e objetivos dos acordos de bitributação, interessa analisar as formas de atuação destes na eliminação da dupla imposição tributária sobre a renda, seu papel principal e mais conhecido.

Inicialmente, é importante esclarecer que, nas regras distributivas dos acordos de bitributação, haverá ocasiões em que a competência tributária será atribuída exclusivamente seja ao Estado da residência ou, mais raramente, ao Estado da fonte. A competência tributária exclusiva é manifestada pela expressão shall be taxable only (em português, "será tributável somente" ou "será tributável apenas"), que esclarece que apenas um dos Estados contratantes poderá tributar o rendimento em questão.

\footnotetext{
${ }^{27}$ Cf. Chris Finnerty et al., op. cit. (nota 6), p. 14.

${ }^{28}$ Cf. Chris Finnerty et al., op. cit. (nota 6), p. 14.

${ }^{29}$ Sobre o objetivo dos acordos de bitributação de incentivo ao comércio internacional, cf. Roberto França de Vasconcellos, op. cit. (nota 22), pp. 153-157.

${ }^{30}$ Cf. Sergio André Rocha, op. cit. (nota 23), p. 49.
} 
Em tais casos, não haverá que se cogitar de dupla tributação, uma vez que a repartição de poderes tributários realizada pelo acordo terá automaticamente eliminado a possibilidade de uma dupla imposição sobre o rendimento.

No entanto, para determinadas categorias de rendimento, o acordo de bitributação não excluirá a competência tributária do Estado da fonte, tampouco do Estado da residência - ambos os Estados poderão exercer sua pretensões tributárias sobre o rendimento em referência, gerando-se, em princípio, uma potencial situação de bitributação.

Nesses casos, o acordo conterá a expressão may be taxed (em português, "poderá ser tributado"), geralmente referindo-se ao Estado da fonte, para evidenciar que tal Estado poderá tributar, sem que isso signifique a exclusão da possibilidade de tributação pelo Estado da residência.

O Estado da fonte, desta forma, poderá tributar o rendimento, com ou sem limitações. É comum que, para determinados tipos de rendimento (tais como dividendos, juros e royalties), haja uma limitação da alíquota a ser aplicada pelo Estado da fonte. Em momento posterior, o Estado da residência terá a obrigação de aplicar o método previsto no acordo, de modo a impedir que ocorra uma situação de dupla tributação. Assim, caberá ao Estado da residência isentar os rendimentos auferidos no Estado da fonte, ou permitir que o contribuinte considere como crédito o imposto pago no Estado da fonte ${ }^{31}$.

Pelo método da isenção, os rendimentos que, pelas regras distributivas do acordo, são tributáveis pelo Estado da fonte ou da situação do bem, serão isentos no Estado da residência $^{32}$. Trata-se de uma medida decorrente do princípio da territorialidade, uma vez que não são tributados os rendimentos obtidos no exterior, mas somente aqueles auferidos internamente ${ }^{33}$.

Com a adoção do método da isenção, ainda que os rendimentos auferidos no exterior não sejam tributados, é possível que sejam levados em consideração, juntamente com os demais rendimentos auferidos internamente, para fins de determinação da alíquota aplicável no Estado da residência - desde que o imposto de renda no Estado da residência

\footnotetext{
${ }^{31}$ Cf. Gerd Willi Rothmann, op. cit. (nota 4), p. 454.

${ }^{32} \mathrm{Cf}$. Comentários à Convenção Modelo da OCDE, Introdução, parágrafo 25.

${ }^{33}$ Cf. Gerd Willi Rothmann, op. cit. (nota 4), p. 453.
} 
seja cobrado mediante alíquotas progressivas, e não proporcionais. É o que se chama de isenção com progressividade ${ }^{34}$. Na hipótese em que os rendimentos auferidos no exterior sequer são considerados, para quaisquer efeitos, tem-se o método da isenção integral ${ }^{35}$.

Já no método do crédito, tradicionalmente utilizado pelo Brasil em seus acordos de bitributação, rendimentos que sejam tributáveis pelo Estado da fonte ou da situação do bem estarão sujeitos à tributação no Estado da residência, mas o imposto pago no Estado da fonte pode ser deduzido do imposto devido no Estado da residência ${ }^{36}$.

O método do crédito, também chamado de método da dedução do imposto ou método da imputação ${ }^{37}$, pode ser aplicado, essencialmente, de duas maneiras, conhecidas como crédito integral (full credit) e crédito ordinário (ordinary credit).

Aplicando-se a modalidade do crédito integral, o Estado da residência tributa seus residentes em bases universais, permitindo que o imposto pago sobre os rendimentos auferidos no exterior seja totalmente utilizado como crédito compensável com o imposto interno devido sobre sua renda mundial ${ }^{38}$.

Já de acordo com o método do crédito ordinário, o qual é o mais usual na prática, o Estado da residência permite que o imposto pago no exterior seja deduzido do imposto devido sobre sua renda mundial, mas limitado ao montante do imposto devido internamente sobre os rendimentos estrangeiros ${ }^{39}$.

\footnotetext{
${ }^{34} \mathrm{O}$ método da isenção com progressividade (ou "reserva de progressividade") está previsto no artigo 23 A (Exemption Method), parágrafo $3^{\circ}$ da Convenção Modelo da OCDE, que assim dispõe:

"ARTICLE 23 A EXEMPTION METHOD

(...)

3. Where in accordance with any provision of the Convention income derived or capital owned by a resident of a Contracting State is exempt from tax in that State, such State may nevertheless, in calculating the amount of tax on the remaining income or capital of such resident, take into account the exempted income or capital." Sobre o assunto, cf. Alberto Xavier, op. cit. (nota 5), pp. 815-816.

${ }^{35}$ Cf. Alberto Xavier, op. cit. (nota 5), pp. 815-816.

${ }^{36} \mathrm{Cf}$. Comentários à Convenção Modelo da OCDE, Introdução, parágrafo 25.

${ }^{37}$ Cf. Gerd Willi Rothmann, op. cit. (nota 4), p. 453.

${ }^{38}$ Cf. Chris Finnerty et al., op. cit. (nota 6), p. 10.

${ }^{39}$ Cf. Chris Finnerty et al., op. cit. (nota 6), p. 10.
} 
Nota-se, assim, que no método do crédito, a tributação pelo Estado da residência é residual, estando atrelada à tributação ocorrida no Estado da fonte. Quanto maior esta última, menor será o imposto devido ao Estado da residência ${ }^{40}$.

Tal situação acaba por gerar um conflito de interesses entre os Estados da fonte e da residência. Por um lado, tem-se que se o montante do imposto pago no Estado da fonte for superior ao imposto devido sobre o mesmo rendimento no Estado da residência, o imposto excedente não será reembolsado de acordo com o método do crédito ordinário. Com isso, há uma pressão para que as alíquotas de tributação na fonte sejam mantidas em patamares baixos, de modo a facilitar a total absorção do imposto pago no Estado da fonte no Estado da residência do investidor ${ }^{41}$.

De outra parte, o Estado da fonte buscará tributar os não residentes no maior nível possível, haja vista que qualquer redução da tributação na fonte não aproveitará ao contribuinte, mas acabará por aumentar o imposto a ser recolhido aos cofres do Estado da residência $^{42}$.

É em tal contexto que surge a discussão acerca da utilização de cláusulas de tax sparing e matching credit, geralmente presente nos instrumentos firmados entre países desenvolvidos e países em desenvolvimento.

\subsection{Limitações do método do crédito e o surgimento das cláusulas de tax sparing e matching credit}

Apresentados os métodos destinados a eliminar ou mitigar a dupla tributação da renda, resta claro que, no que tange aos acordos bilaterais, uma de suas principais funções é a de evitar a dupla tributação, através da repartição de competências e receitas tributárias entre os Estados contratantes.

\footnotetext{
${ }^{40}$ Cf. Luís Eduardo Schoueri. "Tax sparing: uma reconsideração da reconsideração”. OLIVEIRA, Ricardo Mariz de; SCHOUERI, Luís Eduardo; ZILVETI, Fernando Aurelio. Revista Direito Tributário Atual. v. 26. São Paulo: Instituto Brasileiro de Direito Tributário: Dialética, 2011, p. 95.

${ }^{41}$ Cf. Hope Ashiabor. "Tax sparing: a timeworn mechanism in Australia's bilateral tax treaties with its trading partners in Southeast Asia?”. The International Tax Journal. v. 24, 1998, p. 72.

${ }^{42}$ Cf. Luís Eduardo Schoueri, op. cit. (nota 40), p. 95.
} 
Considerando-se que a maioria dos acordos - inclusive os brasileiros - segue, em grande parte, a Convenção Modelo da OCDE, tal alocação de competências e receitas tende a privilegiar o Estado da residência.

Se tal fato não traz maiores prejuízos quando se trata de relações entre países desenvolvidos, na medida em que os fluxos de um Estado contratante para o outro (e viceversa) tendem a ser equilibrados, sabe-se que, na hipótese de acordos entre países desenvolvidos e países em desenvolvimento, estes últimos possivelmente serão afetados pela divisão não equânime das competências e, consequentemente, das receitas tributárias $^{43}$.

Afinal, historicamente, os países em desenvolvimento desempenham o papel de importadores de capital, ao passo que nos países desenvolvidos estão os titulares dos capitais investidos. Na medida em que se privilegia a tributação pelo Estado da residência, o Estado da fonte sofre as consequências de não poder tributar (ou poder tributar de maneira limitada) os rendimentos auferidos em seu território.

É comum que países em desenvolvimento concedam incentivos fiscais ${ }^{44}$, destinados a atrair investimentos estrangeiros para o seu território, como forma de promoção de seu desenvolvimento econômico. No entanto, os investimentos assim concedidos podem ser anulados para o investidor, caso o método para eliminar a bitributação adotado seja o método do crédito.

Assim, imagine-se uma situação envolvendo dois países que tenham celebrado acordo de bitributação que preveja, como método para eliminar a bitributação, o método do crédito:

\footnotetext{
${ }^{43}$ Cf. Sergio André Rocha, op. cit. (nota 23), pp. 46-47; Allison D. Christians. "Tax treaties for investment and aid to Sub-Saharan Africa: a case study". Brooklyn Law Review. v. 71, n. 2, 2005, pp. 660-661.

${ }^{44}$ Por incentivos fiscais, deve-se entender as disposições da lei tributária que, desviando da estrutura geralmente aceita (ou adotada) do imposto de renda, visam a encorajar determinados comportamentos dos contribuintes no desempenho de certas atividades econômicas. Cf. Harry A. Shannon III. "Tax incentives and tax sparing". Intertax. v. 2, fevereiro, 1992, p. 85.
} 


\begin{tabular}{|l|r|}
\hline \multicolumn{2}{|c|}{ Estado da fonte (A) } \\
\hline Juros auferidos & $\$ 100$ \\
\hline Imposto incidente na fonte (15\%) & $(\$ 15)$ \\
\hline Juros líquidos no Estado da fonte & $\$ 85$ \\
\hline \multicolumn{2}{|c|}{ Estado da residência (B) } \\
\hline Juros auferidos & $\$ 100$ \\
\hline Imposto incidente na residência (20\%) & $(\$ 20)$ \\
\hline Crédito na residência & $\$ 15$ \\
\hline Tributação na residência & $(\$ 5)$ \\
\hline \multicolumn{2}{|c|}{ Investidor (A + B) } \\
\hline Juros auferidos & $\$ 100$ \\
\hline Tributação total (A + B) & $(\$ 20)$ \\
\hline Rendimento líquido & $\$ 80$ \\
\hline
\end{tabular}

No exemplo referido na tabela acima, tem-se situação na qual um país em desenvolvimento $\mathrm{A}$, em um primeiro momento, tributa na fonte os juros remetidos ao exterior a uma alíquota de $15 \%$. Um investidor estrangeiro residente em um país B, que possui um acordo de bitributação com o país A, no qual está previsto o método do crédito, resolve aplicar determinado montante no país A. Após certo tempo, o referido investidor aufere \$ 100 a título de juros no país A, e é tributado na fonte, recolhendo aos cofres deste país o montante de $\$ 15$.

No país B, o investidor é tributado a uma alíquota de $20 \%$ sobre o total de seus rendimentos, incluindo aqueles auferidos no país A. Desta forma, deveria pagar, em princípio, \$20, mas como pode deduzir deste montante o crédito de $\$ 15$ relativo ao imposto pago no país $\mathrm{A}$, recolhe ao país $\mathrm{B}$ somente $\$ 5$. A carga tributária total do investidor em questão será de \$20 (\$15 no país A e \$ 5 no país B), correspondendo à aplicação da alíquota mais alta, que é a do Estado da residência (país B).

Continuando esse exercício, imagine-se que, na tentativa de atrair investimentos estrangeiros, o país A reduza a alíquota na fonte sobre os juros de $15 \%$ para $5 \%$. Numericamente, ter-se-ia o seguinte: 


\begin{tabular}{|l|r|}
\hline \multicolumn{2}{|c|}{ Estado da fonte (A) } \\
\hline Juros auferidos & $\$ 100$ \\
\hline Imposto incidente na fonte (5\%) & $(\$ 5)$ \\
\hline Juros líquidos no Estado da fonte & $\$ 95$ \\
\hline \multicolumn{2}{|c|}{ Estado da residência (B) } \\
\hline Juros auferidos & $\$ 100$ \\
\hline Imposto incidente na residência (20\%) & $(\$ 20)$ \\
\hline Crédito na residência & $\$ 5$ \\
\hline Tributação na residência & $(\$ 15)$ \\
\hline \multicolumn{2}{|c|}{ Investidor (A + B) } \\
\hline Juros auferidos & $\$ 100$ \\
\hline Tributação total (A + B) & $(\$ 20)$ \\
\hline Rendimento líquido & $\$ 80$ \\
\hline
\end{tabular}

Nessa situação, o investidor do país B que auferisse um rendimento de juros de \$ 100 pagaria ao país A o montante de \$ 5 a título de imposto retido na fonte. Em seu Estado da residência, o país B, o investidor continuaria sendo tributado a uma alíquota de $20 \%$ sobre os rendimentos auferidos no país A. No entanto, o crédito relativo ao imposto pago no país A seria de apenas $\$ 5$, de modo que o imposto devido ao país B seria de $\$ 15$. Deste modo, a carga tributária total do investidor terá sido, novamente, de $\$ 20$, alterandose, contudo, a divisão da receita tributária entre os dois Estados envolvidos (\$ 5 para o país A e $\$ 15$ para o país B).

Com esses exemplos, é possível perceber que, com a utilização do método do crédito, os incentivos fiscais concedidos pelo Estado da fonte para atrair investimentos estrangeiros acabam sendo anulados, na medida em que nenhum benefício efetivo é revertido para o investidor estrangeiro. Apenas o Estado da residência do investidor estrangeiro é beneficiado, por passar a conceder um crédito inferior ao que seria obrigado na ausência de incentivos fiscais no Estado da fonte, com a consequente elevação do imposto correspondente ${ }^{45}$. O efeito pretendido pelo Estado da residência ao conceder o incentivo fiscal para o investidor do país B, assim, acabou por não se concretizar.

Em situações tais como a analisada, o método do crédito revela-se prejudicial também às empresas do Estado da residência, haja vista que estas terão sua capacidade de

${ }^{45}$ Cf. Roberto França de Vasconcellos, op. cit. (nota 22), p. 167. 
concorrência no mercado internacional reduzida, em face do pesado ônus tributário sobre elas incidente ${ }^{46}$.

Cumpre apontar que as referidas consequências negativas decorrentes da aplicação do método do crédito nas hipóteses em que a tributação foi reduzida no Estado da fonte são objeto de questionamentos por alguns autores e, como se verá adiante, também pela OCDE. Assim, alega-se que a transferência, para o Estado da residência, dos incentivos fiscais concedidos pelo Estado da fonte ao investidor não residente para o Estado da residência deste não necessariamente ocorrerá, por depender da verificação de uma série de fatores ${ }^{47}$.

Nesse passo, entende-se que a transferência de receitas para o Estado da residência do investidor estrangeiro tende a não ocorrer, na medida em que a maior parte dos países que aplicam o método do crédito somente tributam rendimentos auferidos no exterior no momento de sua distribuição, que poderá assim ser diferida no tempo indefinidamente (deferral), o que representa um incentivo ao reinvestimento dos lucros auferidos no Estado da fonte ${ }^{48}$.

Em face de tal argumento, podem ser apresentadas duas objeções principais. A primeira consiste no fato de que, ao se tratar da aplicação do método do crédito e de seus problemas, não se faz referência apenas aos lucros auferidos no exterior por meio de subsidiárias, nas quais existe a possibilidade de postergar a sua distribuição para momento futuro. De fato, há também juros, royalties e outros rendimentos que são auferidos diretamente pelo investidor não residente, não sendo possível aventar-se a possibilidade de diferimento da tributação ${ }^{49}$.

Ademais, ainda que se esteja tratando da hipótese de lucros auferidos por subsidiárias no exterior, é certo que, no momento de sua distribuição, na forma de dividendos, o incentivo fiscal concedido no Estado da fonte será anulado para o investidor

\footnotetext{
${ }^{46}$ Cf. Roberto França de Vasconcellos, op. cit. (nota 22), p. 168.

${ }^{47}$ Cf. Hope Ashiabor, op. cit. (nota 41), p. 73.

${ }^{48}$ Cf. Hope Ashiabor, op. cit. (nota 41), p. 73; Alexander J. Easson. "Tax incentives for foreign direct investment part II: design considerations". Bulletin for International Taxation. v. 55, n. 8, agosto, 2001, p. 374; Jose Andrés Romero. "Why Colombia should negotiate international tax treaties". Tax Notes International. v. 39, n. 4, julho, 2005, p. 374; Kim Brooks. "Tax sparing: a needed incentive for foreign investment in low-income countries or an unnecessary revenue sacrifice?". Queen's Law Journal. v. 34, 2009 , p. 511.

${ }^{49}$ Cf. ORGANISATION FOR ECONOMIC CO-OPERATION AND DEVELOPMENT. Tax sparing: a reconsideration. Paris: ‘, 1998, p. 24.
} 
estrangeiro, uma vez que o crédito do imposto a ser conferido pelo Estado da residência do investidor será inferior, mantendo-se a mesma carga tributária total incidente sobre tal rendimento. Nesse caso, o montante do incentivo fiscal conferido pelo Estado da fonte ao investidor estrangeiro terá sido claramente transferindo ao Estado da residência deste ${ }^{50}$.

Também se alega que não se verificará, necessariamente, uma transferência do incentivo ao Estado da residência do investidor estrangeiro, porque em muitos casos permite-se que, na compensação dos impostos pagos no exterior, seja considerado um limite global do que foi pago em diversos países, fazendo-se uma média dos impostos pagos em excesso, em determinados países, com o que foi pago a menor em outros países, em razão de incentivos fiscais ${ }^{51}$.

Esse segundo argumento somente pode ser considerado verdadeiro se diversos fatores estiverem presentes na situação analisada: em primeiro lugar, é necessário que o investidor atue em diversos países, além do país em desenvolvimento que lhe concedeu um incentivo fiscal; ademais, também é fundamental que, em alguns desses outros países, sejam cobrados impostos em montante superior ao que seria cobrado, sobre os mesmos rendimentos, no Estado da residência, assumindo o investidor uma posição credora; por fim, deverá o Estado da residência permitir que os créditos relativos aos impostos pagos no exterior sejam considerados de forma global, e não limitados por país ${ }^{52}$.

Em suma, os argumentos normalmente utilizados para negar a assertiva de que o método do crédito acaba por anular eventuais incentivos fiscais concedidos pelo Estado da fonte não são válidos, uma vez que partem de situações excepcionais, como as possibilidades de diferimento e de compensação com impostos em excesso pagos em outros países. Em regra, o que se verifica é que se o Estado da fonte concede um incentivo fiscal a um investidor não residente, a aplicação do método do crédito terá por efeito a anulação do referido incentivo, que será transferido ao Estado da residência deste investidor, na forma de maiores receitas tributárias.

Nesse sentido, cumpre mencionar que, em texto publicado em 1986, Nahum Biger e Michael F. G. Pepe analisaram os efeitos dos acordos de bitributação sobre os incentivos

\footnotetext{
${ }^{50}$ Cf. Hope Ashiabor, op. cit. (nota 41), p. 73.

${ }^{51}$ Cf. Hope Ashiabor, op. cit. (nota 41), pp. 73-74.

${ }^{52}$ Em muitos países, adota-se a denominada per-country limitation, mecanismo pelo qual os créditos de imposto passíveis de compensação são considerados por país, separadamente. Cf. IBFD, op. cit. (nota 13), p. 319.
} 
fiscais, relevantes ferramentas de política fiscal doméstica ${ }^{53}$. À luz do acordo de bitributação celebrado entre Canadá e Itália, no qual está previsto o método do crédito para a eliminação da dupla tributação, os autores alertaram para o fato de que, na hipótese de o governo canadense conceder determinado incentivo fiscal a rendimentos auferidos no Canadá por investidores residentes na Itália, uma parte ou a totalidade de tal benefício seria acabaria por ser transferida, na forma de receitas tributárias, ao governo italiano ${ }^{54}$.

$\mathrm{Na}$ realidade, qualquer incentivo fiscal concedido pelo governo canadense que reduza a tributação na fonte, no Canadá, a uma alíquota inferior àquela que incidirá na Itália sobre estes mesmos rendimentos, acabaria por beneficiar os cofres públicos italianos, e não o investidor residente na Itália ${ }^{55}$.

Como possíveis soluções para combater essa transferência de riqueza entre os Estados contratantes, que na opinião dos autores certamente não foi pretendida pelos negociadores do Acordo Canadá-Itália e dos demais acordos canadenses nos quais se insere o método do crédito para eliminar a dupla tributação, são apresentadas duas sugestões: a primeira delas é a utilização do método da isenção nos acordos de bitributação, em substituição ao método do crédito; a segunda consiste em um exame minucioso dos incentivos fiscais concedidos aos investidores não residentes, avaliando-se se os sacrifícios da concessão de tais benefícios efetivamente são transferidos a seus destinatários, e não ao Estado da residência destes ${ }^{56}$.

Os autores mencionam ainda uma terceira forma de combater os efeitos indesejados da utilização do método do crédito em face de incentivos fiscais concedidos pelo Estado da fonte, qual seja, a cláusula de tax sparing.

Com efeito, de modo a mitigar as consequências aqui analisadas, foram criados determinados tipos de cláusulas que asseguram que o sacrifício fiscal sofrido pelo Estado da fonte será revertido em benefício para o investidor estrangeiro, e não para o Estado da residência deste. Têm-se, assim, as cláusulas de tax sparing, que substituem o método do crédito puro e simples.

\footnotetext{
${ }^{53}$ Cf. Nahum Biger e Michael F. G. Pepe. "The inhibiting effect of bilateral tax treaties on domestic tax incentives". Canadian Public Policy / Analyse de Politiques. v. 12, n. 3, setembro, 1986, pp. 424-431.

${ }_{54}$ Cf. Nahum Biger e Michael F. G. Pepe, op. cit. (nota 53), p. 427.

${ }^{55}$ Cf. Nahum Biger e Michael F. G. Pepe, op. cit. (nota 53), p. 428.

${ }^{56}$ Cf. Nahum Biger e Michael F. G. Pepe, op. cit. (nota 53), pp. 428-429.
} 
Nahum Biger e Michael F. G. Pepe acabaram por descartar a viabilidade da adoção de cláusulas de tax sparing para o Canadá (ou outros países desenvolvidos) por entenderem que este mecanismo somente deve ser considerado por países menos desenvolvidos quando da negociação de seus acordos ${ }^{57}$.

\subsection{Cláusulas de tax sparing e matching credit}

Conforme mencionado, na sistemática dos acordos contra a dupla tributação, de um modo geral, o crédito a ser deduzido do imposto devido no Estado da residência leva em consideração o imposto efetivamente pago no Estado da fonte.

Contudo, não é isso que acontece nas cláusulas de tax sparing e de matching credit $^{58}$, normalmente presentes em acordos negociados entre países desenvolvidos e países em desenvolvimento, que não tomam por base o imposto efetivamente pago no Estado da fonte, diferentemente do que ocorre no método do crédito, seja integral ou ordinário $^{59}$.

Deve-se notar que as cláusulas de tax sparing e matching credit também podem ser relevantes para países que adotam, de maneira predominante, o método da isenção, haja vista que tais países podem utilizar o método do crédito para determinados rendimentos auferidos no exterior ${ }^{60}$.

Muito embora as discussões atuais acerca de tais institutos recaiam principalmente sobre a questão de sua efetividade, diversos problemas que surgem quando da aplicação dessas cláusulas estão relacionados à imprecisão na definição das duas expressões ${ }^{61}$. Por tal motivo, cumpre conceituá-las adequadamente.

\footnotetext{
${ }^{57}$ Cf. Nahum Biger e Michael F. G. Pepe, op. cit. (nota 53), p. 430.

58 Referidas, por vezes, pela doutrina pátria, como cláusulas de crédito fictício (tax sparing) e crédito presumido (matching credit). É a denominação adotada, por exemplo, por Alberto Xavier. A este respeito, cf. Alberto Xavier, op. cit. (nota 5), pp. 823-827. No presente trabalho, a referida nomenclatura não será acatada, preferindo-se utilizar, tão somente, tais termos em seu idioma original - tax sparing e matching credit - a fim de evitar imprecisões terminológicas.

${ }^{59}$ Cf. Alberto Xavier, op. cit. (nota 5), p. 823.

${ }^{60}$ Cf. OCDE, op. cit. (nota 1), p. 20.

${ }^{61}$ Cf. Anapaula Trindade Marinho e Vanessa Arruda Ferreira. "Crédito de imposto fictício: de uma noção nebulosa a um regime jurídico incerto”. Revista de Direito Tributário Internacional. v. 11. São Paulo: Quartier Latin, 2009, p. 13.
} 
Porém, antes disso, discutir-se-á, ainda que de forma breve, a distinção adotada, para fins do presente trabalho, entre países desenvolvidos e países em desenvolvimento, bem como o papel dos incentivos fiscais e das próprias cláusulas de tax sparing na atração de investimentos estrangeiros pelos países em desenvolvimento.

\subsubsection{Principais premissas adotadas}

Na discussão acerca das cláusulas de tax sparing e maching credit, a referência a "países desenvolvidos" e "países em desenvolvimento" é mais do que uma constante, tornando-se praticamente obrigatória e indispensável.

Tal situação ocorre porque as referidas cláusulas normalmente estão presentes nos acordos de bitributação celebrados entre países com diferentes graus de desenvolvimento econômico, aplicando-se as cláusulas de tax sparing e matching credit para fins de determinação do crédito a ser compensado no Estado da residência do investidor que auferiu rendimentos no país em desenvolvimento.

Conforme se demonstrará, embora esta seja a regra, há acordos de bitributação em que as cláusulas de tax sparing e matching credit são recíprocas, aplicando-se indistintamente ao país desenvolvido e ao país em desenvolvimento, ou mesmo aos dois países em desenvolvimento que tenham inserido tais cláusulas em seu acordo de bitributação $^{62}$.

De qualquer forma, ainda que haja exceções, cumpre delinear brevemente os conceitos de países desenvolvidos e países em desenvolvimento, os quais permearão boa parte do presente trabalho.

Mauro José Silva relata as dificuldades existentes na definição de tais termos, sendo vários os critérios adotados por diversos autores e organizações internacionais, que conduzem a diferentes resultados ${ }^{63}$.

\footnotetext{
${ }^{62}$ Mais raramente, há hipóteses de cláusulas de tax sparing e matching credit também em acordos de bitributação celebrados entre dois países desenvolvidos, como se mencionará mais adiante.

${ }^{63}$ Cf. Mauro José Silva. Da competição à cooperação internacional: aspectos jurídicos da promoção ao desenvolvimento nacional num cenário internacionalizado. Tese de doutorado. São Paulo: Universidade de São Paulo, 2009, pp. 16-20.
} 
Diante de tal situação, o autor opta por uma definição concreta apoiada em dados do Banco Mundial. De acordo com esse critério, países em desenvolvimento são aqueles que não são relacionados pelo Banco Mundial como sendo países de alta renda. Consequentemente, os países desenvolvidos são os países de alta renda, conforme estabelecido pelo Banco Mundial ${ }^{64}$.

Ao adotar tal critério, Mauro José Silva reconhece que há outros fatores importantes para a determinação do grau de desenvolvimento de um país que não se refletem na renda per capita de sua população. De qualquer forma, entende o autor que a renda per capita elevada costuma traduzir-se em melhores indicadores sociais, tais como acesso à saúde, educação e melhor distribuição de renda ${ }^{65}$.

Claudio Sachetto também analisou os referidos conceitos, chegando à conclusão de que as definições normalmente adotadas para as expressões em comento descrevem apenas aspectos particulares de uma realidade que é instável e dinâmica ${ }^{66}$.

No mesmo sentido, a ONU indica que as designações "países desenvolvidos" e "países em desenvolvimento" são feitas em função de conveniências estatísticas, não correspondendo, necessariamente, a um juízo de valor relativo ao grau de desenvolvimento econômico alcançado por um país ${ }^{67}$.

No entanto, em razão da necessidade de definição, seja para fins científicos, seja para a aplicação das medidas econômicas e fiscais consequentes, Claudio Sachetto vale-se do conceito de países emergentes (emerging countries), como sendo aquele país com grandes potencialidades econômicas, como recursos naturais, e atitudes ou vontade de melhorar seus padrões de desenvolvimento, com vistas a alcançar os padrões dos países desenvolvidos ${ }^{68}$.

\footnotetext{
${ }^{64}$ Cf. Mauro José Silva, op. cit. (nota 63), p. 19.

${ }^{65}$ Cf. Mauro José Silva, op. cit. (nota 63), p. 19.

${ }^{66}$ Cf. Claudio Sacchetto. "Política de tratados em matéria tributária para países emergentes vis-à-vis países desenvolvidos e em via de desenvolvimento". Tradução de Jonathan Barros Vita. COSTA, Alcides Jorge; SCHOUERI, Luís Eduardo; BONILHA, Paulo Celso Bergstrom (coords.). Direito Tributário Atual. v. 23. São Paulo: Dialética: IBDT, 2009, p. 74.

${ }^{67}$ Cf. ORGANIZAÇÃO DAS NAÇÕES UNIDAS. Manual for the Negotiation of Bilateral Tax Treaties between Developed and Developing Countries. New York: UN, 2003, p. ii.

${ }^{68}$ Cf. Claudio Sacchetto, op. cit. (nota 66), p. 74.
} 
Em 1998, ao publicar o relatório "Tax sparing: a reconsideration" (doravante denominado "Relatório da OCDE"), a OCDE já questionava o fato de que as condições econômicas de muitos dos países que no passado eram tidos como "em desenvolvimento" eram superiores, naquele momento, às condições de diversos Estados membros da $\mathrm{OCDE}^{70}$.

Assim, mencionava-se que diversos países asiáticos e latino-americanos já eram grandes players da economia mundial, representando parcela significativa do comércio e dos investimentos globais ${ }^{71}$. Desta forma, haveria, na atualidade, uma distribuição mais balanceada nos fluxos de comércio e investimento entre os Estados membros e os Estados não membros da $\mathrm{OCDE}^{72}$.

No contexto atual da crise econômica mundial que atinge a Europa de maneira mais profunda, questionamentos desse tipo certamente seriam ainda mais incisivos, sobretudo no que diz respeito ao Brasil, que foi alçado, nos últimos anos, ao posto de uma das maiores economias mundiais.

Contudo, não se pode concordar com o posicionamento da OCDE, que peca ao considerar apenas os indicadores econômicos dos países, sem atentar para outros indicativos do desenvolvimento econômico, tais como acesso à saúde e educação, nível de industrialização, participação no desenvolvimento de tecnologias $\operatorname{etc}^{73}$.

Nesse passo, é certo que a economia brasileira de hoje é muito mais desenvolvida do que nas décadas de 1960 e 1970. Não obstante, tal conclusão não parece suficiente para que se afirme que o Brasil deixou de ser um país em desenvolvimento, haja vista os resultados atingidos pelo país em seus indicadores sociais.

Mencione-se, nesse sentido, que o Brasil foi o $84^{\circ}$ colocado no ranking do Índice de Desenvolvimento Humano ("IDH”) Global 2011, atrás de países como Peru, Equador,

\footnotetext{
${ }^{69}$ Cf. OCDE, op. cit. (nota 1). O conteúdo do referido relatório será analisado, em detalhes, em tópico posterior do presente trabalho.

${ }^{70}$ Cf. OCDE, op. cit. (nota 1), p. 9.

${ }^{71}$ Cf. OCDE, op. cit. (nota 1), p. 9.

${ }^{72}$ Cf. OCDE, op. cit. (nota 1), p. 9.

${ }^{73}$ Cf. Cristiane Coelho. "Tax sparing and Brazil's tax treaties". Tax Notes International. v. 51, n. 8, agosto, 2008, pp. 692-693.
} 
Venezuela e Panamá ${ }^{74}$. Em tal ranking, são analisados os índices de educação, renda e expectativa de vida ao nascer dos habitantes de um país.

Ademais, como afirma Luís Eduardo Schoueri, o nível de desenvolvimento da economia brasileira não é uniforme: enquanto o sul/sudeste apresenta certo grau de desenvolvimento próprio e independente de programas governamentais, há diversas regiões no norte/nordeste que dependem de investimentos externos para seu desenvolvimento, para fins de geração de emprego e melhoria da qualidade de vida da população $^{75}$.

Mesmo a OCDE, que como já mencionado, aponta de maneira peremptória que diversos países em desenvolvimento possuem atualmente indicadores econômicos que chegam a superar o de seus Estados membros, reconhece que a maioria dos países em desenvolvimento continua a depender da importação de capitais para suportar seu desenvolvimento, e que tal situação não mudaria em um futuro imediato ${ }^{76}$.

Nesse passo, para fins do presente trabalho, adota-se a premissa de que o Brasil é um país em desenvolvimento, i.e., embora sua participação na economia mundial tenha ganhado grande relevo e destaque nos últimos tempos, é certo que seu desenvolvimento econômico não é uniforme e que seus indicadores sociais encontram-se em patamar de desenvolvimento bastante incipiente.

Uma vez delineado, em linhas gerais, o conceito de país em desenvolvimento adotado para fins do presente estudo, cumpre apontar qual seria o papel dos incentivos fiscais destinados a promover o ingresso de investimentos estrangeiros no desenvolvimento econômico de tais países.

A este respeito, Roberto França de Vasconcellos afirma que, na Economia, admitese como verdadeira a ideia de que o investimento estrangeiro é uma forma de impulsionar

74 Cf. PNUD - Programa das Nações Unidas para o Desenvolvimento. Relatório do Desenvolvimento Humano de 2011. Sustentabilidade e Equidade: Um Futuro Melhor para Todos. New York: PNUD. Disponível em: <http://hdr.undp.org/en/media/HDR_2011_PT_Complete.pdf>. Acesso em: 15 de outubro de 2012.

${ }^{75}$ Cf. Luís Eduardo Schoueri. "Contribuição à história dos acordos de bitributação: a experiência brasileira". COSTA, Alcides Jorge; SCHOUERI, Luís Eduardo; BONILHA, Paulo Celso Bergstrom (coords.). Direito Tributário Atual. v. 22. São Paulo: Dialética: IBDT, 2008, p. 282.

${ }^{76}$ Cf. OCDE, op. cit. (nota 1), p. 10. 
o crescimento econômico dos países, na medida em que se aumenta o estoque de capital na economia, com a geração de maior produtividade e salários ${ }^{77}$.

Adotando-se como premissa o fato de que o investimento estrangeiro tende a gerar crescimento econômico, sobretudo nos países em desenvolvimento, ainda resta a questão: seria a concessão de incentivos fiscais destinados à atração de investimentos estrangeiros instrumento efetivo para tal finalidade?

Trata-se de pergunta para a qual não se conhece, ao certo, a resposta. Sabe-se que a concessão de incentivos fiscais é vista de maneira positiva pelos investidores e tende a criar um ambiente favorável aos investimentos, bem como que tais incentivos podem compensar outros eventuais riscos a que o investidor estaria sujeito ${ }^{78}$.

Contudo, alega-se que não há indicativos claros de que os incentivos fiscais de fato constituem a principal razão para a realização de um investimento em determinado país, e que ainda que se entenda que os incentivos fiscais representem um encorajamento aos investimentos, tal assertiva é de difícil quantificação e confirmação ${ }^{79}$.

Assim, para alguns autores, a concessão de incentivos fiscais pelos países em desenvolvimento tem como único efeito a erosão de suas receitas tributárias e a competição indiscriminada por investimentos estrangeiros entre os vários países em desenvolvimento, que nessa jornada reduzem, cada vez mais, os níveis de sua tributação (race to the bottom $)^{80}$.

Mais recentemente, a OCDE, após se posicionar de maneira contrária à concessão de incentivos fiscais, em razão de sua alegada ineficácia, parece sugerir que estes são mais eficazes hoje do que no passado ${ }^{81}$. Isso também tem sido sugerido por pesquisas mais

\footnotetext{
${ }^{77}$ Cf. Roberto França de Vasconcellos, op. cit. (nota 22), p. 171.

${ }^{78}$ Cf. Harry A. Shannon III, op. cit. (nota 44), p. 87.

${ }^{79}$ Cf. Harry A. Shannon III, op. cit. (nota 44), p. 87.

${ }^{80}$ Cf. Kim Brooks, op. cit. (nota 48), pp. 514-515; 531-547. Cf. também: Alexander J. Easson. "Tax incentives for foreign direct investment part I: recent trends and countertrends". Bulletin for International Taxation. v. 55, n. 7, julho, 2001, pp. 269-270.

${ }^{81}$ Cf. ORGANIZAÇÃ̃O PARA A COOPERAÇÃO E DESENVOLVIMENTO ECONÔMICO. Tax effects on Foreign Direct Investment: recent evidence and policy analysis. Paris: OCDE, 2007; Kim Brooks, op. cit. (nota 48), p. 530; Cristiane Coelho, op. cit. (nota 73), p. 696.
} 
recentes, contrariando o entendimento anterior de que incentivos fiscais não eram efetivos na atração de investimentos estrangeiros ${ }^{82}$.

Na linha do que defende Mauro José Silva, adota-se o entendimento de que, embora diversos outros fatores sejam sopesados nas decisões de investimento, tais como estabilidade política e econômica, adequada infraestrutura, ausência de burocracia, disponibilidade de mão de obra qualificada etc., também as considerações de cunho tributário são determinantes para os investidores estrangeiros, na escolha dos países em que irão alocar seus investimentos, cabendo aos incentivos fiscais importante papel nessa opção $^{83}$.

De qualquer forma, ainda que se entenda que os incentivos fiscais são desejáveis e aumentam o fluxo de investimentos estrangeiros para os países em desenvolvimento, gerando desenvolvimento econômico, também se questiona a efetividade das cláusulas de tax sparing em perseguir tal objetivo, sob o fundamento de que não haveria evidências suficientes de que tal mecanismo é eficaz no fomento aos incentivos fiscais dos países em desenvolvimento e na atração de investimentos estrangeiros ${ }^{84}$.

Contrariando tal argumento, mencione-se o estudo de James R. Hines Jr., que comparou fluxos de investimentos americanos e japoneses, no mesmo período, para países em desenvolvimento, sendo que nos acordos de bitributação celebrados pelo Japão, diferentemente dos firmados pelos Estados Unidos, havia a previsão de cláusulas de tax sparing ${ }^{85}$.

Após a análise econômica dos dados concretos, o autor verificou que o volume dos investimentos japoneses nos países em desenvolvimento com os quais o Japão possuía acordos de bitributação com cláusulas de tax sparing era muito superior ao volume dos

\footnotetext{
${ }^{82}$ Cf. Alexander J. Easson, op. cit. (nota 80), pp. 271-272; William B. Barker. "An international tax system for emerging economies, tax sparing, and development: it is all about source!". University of Pennsylvania Journal of International Law. v. 29, n. 2, 2007, p. 365.

${ }^{83}$ Cf. Mauro José Silva, op. cit. (nota 63), pp. 31-32.

${ }^{84} \mathrm{Cf}$. Yariv Brauner. "Por que os Estados Unidos firmam tratados tributários? E por que não têm tratado tributário com o Brasil?”. Tradução de Célia Korn. OLIVEIRA, Ricardo Mariz de; SCHOUERI, Luís Eduardo; ZILVETI, Fernando Aurelio. Revista Direito Tributário Atual. v. 26. São Paulo: Instituto Brasileiro de Direito Tributário: Dialética, 2011, p. 125; William B. Barker, op. cit. (nota 82), p. 363; Morvan Meirelles. "Tax sparing credits in tax treaties: the future and the effect on EC law". European Taxation. maio, 2009, p. 265-267.

${ }^{85}$ Cf. James R. Hines Jr.. “'Tax sparing' and direct investment in developing countries”. NBER Working Paper No. 6728. Cambridge: National Bureau of Economic Research. setembro, 1998, pp. 1-47. Disponível em: <http://www.nber.org/papers/w6728>. Acesso em: 04 de novembro de 2012.
} 
investimentos americanos nesses mesmos países. Com base em tais evidências, James R. Hines Jr. concluiu que a existência de cláusulas de tax sparing em acordos de bitributação é fator que influencia o nível de investimentos estrangeiros diretos nos países em desenvolvimento ${ }^{86}$.

Resultados semelhantes, também baseados em dados empíricos, foram obtidos nos estudos de Céline Azémar, Andrew Delios, Rodolphe Desbordes e Jean-Louis Mucchielli, os quais concluíram, assim, que o tax sparing é um fator considerado pelos investidores estrangeiros ao tomar decisões relativas à alocação de seus investimentos ${ }^{87}$.

Para fins do presente trabalho, parte-se da premissa de que a atração de investimentos estrangeiros deve ser considerada, de modo geral, como um instrumento efetivo de desenvolvimento econômico dos países em desenvolvimento, sendo a concessão de incentivos fiscais um importante fator analisado pelos investidores na escolha de onde aportar seus investimentos. Nesse contexto, na linha dos estudos mencionados, a existência de cláusulas de tax sparing é elemento que serve de estímulo aos investimentos estrangeiros nos países em desenvolvimento.

\subsubsection{Cláusulas de tax sparing}

O tax sparing é um crédito que corresponde ao imposto que teria sido pago no Estado da fonte, na ausência de benefícios fiscais com o intuito de incentivar o investimento estrangeiro em tal Estado. Pretende-se, no tax sparing, que os incentivos fiscais concedidos pelo Estado da fonte sejam efetivamente fruídos pelo investidor, e não pelo Estado da residência.

No exemplo desenvolvido anteriormente, a alíquota normalmente aplicável na fonte sobre as remessas de juros ao exterior era de 15\%, mas o Estado da fonte (país A) entendeu por bem reduzir tal alíquota para 5\%, como forma de buscar atrair investimentos

\footnotetext{
${ }^{86}$ Cf. James R. Hines Jr., op. cit. (nota 85), pp. 28-29.

${ }^{87}$ Cf. Céline Azémar e Andrew Delios. "Tax competition and FDI: the special case of developing countries". Journal of Japanese and International Economies. v. 22, 2008, pp. 85-108; Céline Azémar, Rodolphe Desbordes e Jean-Louis Mucchielli. "Do tax sparing agreements contribute to the attraction of FDI in developing countries?”. International Tax and Public Finance. v. 14, n. 5, 2007, pp. 543-562.
} 
estrangeiros. No país B, Estado da residência do investidor retratado no exemplo, a alíquota sobre os rendimentos globais de tal contribuinte é de $20 \%$.

Na ausência de cláusula de tax sparing, conforme foi possível notar, o incentivo fiscal concedido pelo Estado da fonte (país A) acabou por ser anulado, uma vez que o sacrifício sofrido por este Estado reverteu-se em aumento das receitas tributárias do Estado da residência do investidor (país B). De outra parte, a carga tributária total a que estava sujeito o investidor não residente restou idêntica, de tal sorte que a concessão de incentivo fiscal pelo país A não se traduziu em qualquer beneficio para este.

Contudo, tal cenário seria diferente se, no acordo de bitributação celebrado entre país A e país B, houvesse uma cláusula de tax sparing, pela qual o país B seria obrigado a conceder um crédito equivalente ao imposto que teria sido pago pelo investidor no país A, na ausência de incentivos fiscais destinados a atrair investidores estrangeiros. De fato, tal situação poderia ser representada, em números, da seguinte maneira:

\begin{tabular}{|l|r|}
\hline \multicolumn{2}{|c|}{ Estado da fonte (A) } \\
\hline Juros auferidos & $\$ 100$ \\
\hline Imposto incidente na fonte (5\%) & $(\$ 5)$ \\
\hline Juros líquidos no Estado da fonte & $\$ 95$ \\
\hline \multicolumn{2}{|c|}{ Estado da residência (B) } \\
\hline Juros auferidos & $\$ 100$ \\
\hline Imposto incidente na residência (20\%) & $(\$ 20)$ \\
\hline Crédito na residência & $\$ 15$ \\
\hline Tributação na residência & $(\$ 5)$ \\
\hline \multicolumn{2}{|c|}{ Investidor (A + B) } \\
\hline Juros auferidos & $\$ 100$ \\
\hline Tributação total (A + B) & $(\$ 10)$ \\
\hline Rendimento líquido & $\$ 90$ \\
\hline
\end{tabular}

Expondo a questão de maneira simplificada, o tax sparing nada mais é do que o crédito excedente ao crédito que corresponde aos tributos sobre a renda efetivamente pagos no Estado da fonte ${ }^{88}$. Note-se que, no tax sparing, o crédito do imposto normalmente estará

${ }^{88}$ Cf. IBFD, op. cit. (nota 13), p. 432. 
limitado à alíquota máxima adotada pelo Estado da fonte, com base no acordo de bitributação $^{89}$.

As cláusulas de tax sparing foram desenvolvidas com o intuito de, em situações como a analisada, respeitar-se a competência tributária do Estado da fonte, bem como evitar que os incentivos fiscais concedidos com o intuito de atrair investimentos estrangeiros sejam negados pelo Estado da residência ${ }^{90}$.

No tocante à sua natureza, o tax sparing é tradicionalmente entendido como parte de políticas fiscais de auxílio, promovidas por países desenvolvidos, com a finalidade de promover o desenvolvimento industrial, comercial e científico, dentre outras formas, nos países em desenvolvimento ${ }^{91}$.

Prosseguindo na análise da questão sob a perspectiva dos países desenvolvidos, o tax sparing também é notado como moeda de troca em negociações de acordos de bitributação, haja vista que em muitas situações os países desenvolvidos somente concordam em conceder o tax sparing para os países em desenvolvimento se receberem, em contrapartida, determinados benefícios, tais como redução dos níveis tributação na fonte sobre dividendos, juros e royalties, ou regras menos abrangentes para a caracterização de estabelecimentos permanentes ${ }^{92}$.

O tax sparing nos acordos de bitributação pode adotar um caráter genérico ou fazer referência a um incentivo fiscal específico, previsto na legislação do Estado da fonte.

No primeiro caso, a formulação da cláusula de tax sparing é ampla e abstrata, mencionando-se que o Estado da residência concederá o crédito correspondente ao imposto que teria sido pago no Estado da fonte, na ausência de incentivos fiscais destinados à promoção de seu desenvolvimento econômico ${ }^{93}$.

\footnotetext{
${ }^{89}$ Cf. Agostinho Toffoli Tavolaro. "Tratado Brasil/EUA sobre tributação de renda e de capital”. TORRES, Heleno Taveira (coord.). Direito Tributário e Ordem Econômica: Homenagem aos 60 anos da ABDF. São Paulo: Quartier Latin, 2010, p. 760.

${ }^{90}$ Cf. IBFD, op. cit. (nota 13), p. 432.

${ }^{91}$ Cf. OCDE, op. cit. (nota 1), p. 19.

92 Cf. OCDE, op. cit. (nota 1), p. 19; Jeffrey Owens e Torsten Fensby. "Is there a need to re-evaluate tax sparing?”. Intertax. v. 26, n. 10, 1998, p. 275; Kim Brooks, op. cit. (nota 48), pp. 556-557; Cristiane Coelho, op. cit. (nota 73), p. 689.

${ }^{93}$ Cf. Hope Ashiabor, op. cit. (nota 41), p. 77.
} 
Ainda que se esteja no âmbito de fórmulas genéricas de tax sparing, os países desenvolvidos frequentemente requerem, aos países em desenvolvimento, a indicação precisa de quais são os incentivos fiscais a serem considerados para fins de concessão do tax sparing ${ }^{94}$.

Outra modelagem possível consiste na referência expressa à legislação interna do Estado da fonte na qual está previsto o incentivo fiscal que será objeto do tax sparing ${ }^{95}$. Este mecanismo é considerado mais transparente, haja vista que evita que alterações radicais nas políticas de incentivos fiscais dos países em desenvolvimento afetem as receitas tributárias dos países desenvolvidos. Desta feita, os últimos tendem a ser mais receptivos à negociação de cláusulas de tax sparing que tenham tal formato ${ }^{96}$.

Por outro lado, ainda que na perspectiva dos países desenvolvidos as cláusulas específicas de tax sparing sejam as mais desejáveis, sabe-se que estas são de difícil entendimento, já que raramente os representantes do Estado da residência estão suficientemente familiarizados com o conteúdo da legislação interna do Estado da fonte ${ }^{97}$.

Além de todas as críticas normalmente tecidas ao tax sparing, que serão exploradas em maiores detalhes nos capítulos seguintes, são aventadas também as dificuldades encontradas na aplicação do mecanismo.

Isso porque não é simples a tarefa do Estado da residência de verificar qual é o montante do tributo que teria sido pago no Estado da fonte na ausência de incentivos fiscais. Sugere-se, assim que a Administração Tributária do Estado da fonte forneça esta informação, que deverá ser repassada, pelo contribuinte, à Administração Tributária do Estado da residência ${ }^{98}$. Não se trata, de qualquer forma, de procedimento de fácil aplicação, sendo exigidos certos esforços das Administrações Tributárias envolvidas, assim como dos contribuintes.

Embora as cláusulas de tax sparing normalmente estejam presentes nos acordos de bitributação celebrados entre países desenvolvidos e países em desenvolvimento e sejam previstos de forma unilateral, i.e., somente com relação aos rendimentos auferidos no país

\footnotetext{
${ }^{94}$ Cf. Hope Ashiabor, op. cit. (nota 41), p. 78.

${ }^{95}$ Cf. Hope Ashiabor, op. cit. (nota 41), p. 78; Kim Brooks, op. cit. (nota 48), pp. 560-561.

${ }^{96}$ Cf. Hope Ashiabor, op. cit. (nota 41), p. 80.

${ }^{97}$ Cf. Hope Ashiabor, op. cit. (nota 41), p. 80.

${ }^{98}$ Cf. Hope Ashiabor, op. cit. (nota 41), p. 77.
} 
em desenvolvimento (este na situação de Estado da fonte), há também casos em que a cláusula de tax sparing é recíproca, aproveitando tanto ao país desenvolvido quanto ao país em desenvolvimento 99 .

Como afirma Alexander J. Easson, não são os países em desenvolvimento os únicos a oferecer incentivos fiscais como forma de atração de investimentos, sobretudo para suas regiões menos desenvolvidas. Desta forma, parece-lhe legítima a adoção do tax sparing em bases recíprocas, para que também os incentivos concedidos pelos países desenvolvidos não sejam anulados em função da aplicação do método do crédito ${ }^{100}$.

Kim Brooks, diferentemente, entende que além de as cláusulas de tax sparing deverem estar presentes apenas nos acordos de bitributação entre países desenvolvidos e países em desenvolvimento, devem ser sempre unilaterais. As cláusulas de tax sparing recíprocas, em seu entender, apenas facilitam a erosão das receitas tributárias dos países desenvolvidos, encorajando uma indesejável competição tributária entre os países em desenvolvimento ${ }^{101}$.

\subsubsection{Cláusulas de matching credit}

Normalmente, faz-se referência conjunta ao tax sparing e ao matching credit, adotando-se a premissa de que as duas modalidades de crédito de imposto mencionadas foram criadas com a intenção de fazer com que a renúncia fiscal suportada pelos países em desenvolvimento pudesse de fato ser revertida em benefício para o investidor estrangeiro, e não para o Estado da residência deste, situação que ocorre com a aplicação do método do crédito puro e simples ${ }^{102}$. No entanto, deve-se reconhecer que se trata de mecanismos distintos, embora guardem semelhanças entre si.

Com efeito, o matching credit é mecanismo pelo qual se prevê que o Estado da residência concederá um crédito fixo, em montante normalmente superior ao imposto que

\footnotetext{
${ }^{99}$ Cf. Alexander J. Easson. "The evolution of Canada's tax treaty policy since the Royal Commission on Taxation”. Osgoode Hall Law Journal. v. 26, n. 3, 1988, p. 522.

${ }^{100}$ Cf. Alexander J. Easson, op. cit. (nota 99), p. 522.

${ }^{101}$ Cf. Kim Brooks, op. cit. (nota 48), pp. 558-559.

${ }^{102}$ Cf. Anapaula Trindade Marinho e Vanessa Arruda Ferreira, op. cit. (nota 61), p. 12.
} 
pode ser cobrado pelo Estado da fonte, seja em função de sua legislação interna ou das próprias regras distributivas do acordo de bitributação ${ }^{103}$.

Claudio Sacchetto afirma que o matching credit é considerado uma evolução do tax sparing $^{104}$. De fato, Guy Guest relata que o matching credit surgiu para resolver determinadas insuficiências e dificuldades do tax sparing, que eram sentidas tanto pelos países desenvolvidos quanto pelos países em desenvolvimento ${ }^{105}$.

Nesse sentido, o autor francês menciona que os países em desenvolvimento ressentiam-se do fato de os países desenvolvidos poderem, de certa forma, questionar os incentivos fiscais concedidos no âmbito do tax sparing; os países desenvolvidos, por sua vez, mencionavam o risco de que os países em desenvolvimento, desejosos de atrair mais investimentos para o seu território, majorassem as alíquotas "normais" de sua legislação de modo a aumentar o montante do crédito a ser concedido pelo Estado da residência; por fim, também no Estado da residência, havia a dificuldade prática da determinação do montante do crédito a ser concedido, que dependia da prova da legislação do Estado da fonte ${ }^{106}$.

Destarte, o matching credit independe da existência de um incentivo fiscal, haja vista que, no próprio acordo de bitributação, o Estado da residência concorda em conceder um crédito (geralmente) superior à alíquota vigente no Estado da fonte e no próprio acordo de bitributação ${ }^{107}$. Trata-se, sem dúvidas, de um método de aplicação mais simples do que a do tax sparing ${ }^{108}$.

Luís Eduardo Schoueri afirma que, enquanto o tax sparing está relacionado aos incentivos fiscais concedidos unilateralmente, para que não sejam anulados pela aplicação do método do crédito, o matching credit vai além, servindo claramente como instrumento para o incentivo a investimentos ${ }^{109}$.

\footnotetext{
${ }^{103}$ Cf. Klaus Vogel. On double taxation conventions: a commentary to the OECD, UN, and US model conventions for the avoidance of double taxation on income and capital, with particular reference to German treaty practice. 3. ed. London: Kluwer Law International, 1997, p. 1.256.

${ }^{104}$ Cf. Claudio Sacchetto, op. cit. (nota 66), p. 81.

105 Cf. Guy Guest. «L'affaire des crédits d'impôt brésiliens, ou les limites de l'interprétation littérale des conventions ». Revue de Droit Fiscal. n. 50, dezembro, 2006, p. 2.128.

${ }^{106}$ Cf. Guy Guest, op. cit. (nota 105), p. 2.128.

${ }^{107}$ Cf. Hope Ashiabor, op. cit. (nota 41), pp. 81-83.

${ }^{108}$ Cf. Klaus Vogel, op. cit. (nota 103), p. 1.256.

${ }^{109}$ Cf. Luís Eduardo Schoueri. "Acordos de bitributação e incentivos fiscais: o papel das cláusulas de tax sparing e matching credit”. MARTINS, Ives Gandra da Silva; ELALI, André; PEIXOTO, Marcelo Magalhães (coords.). Incentivos fiscais: questões pontuais nas esferas federal, estadual e municipal. São Paulo: MP Editora, 2007, pp. 260-261.
} 
Nesse sentido, o desenvolvimento das cláusulas de matching credit remonta também ao fato de que, nos acordos de bitributação celebrados entre países com graus diferentes de desenvolvimento, geralmente o fluxo de investimentos é maior em um dos sentidos (do país desenvolvido para o país em desenvolvimento), sendo a renúncia fiscal efetuada pelo Estado da fonte definitiva.

Diferentemente, nos acordos celebrados entre países com o mesmo grau de desenvolvimento, os fluxos bilaterais de rendimentos fazem com que as renúncias fiscais de um dos Estados sejam compensadas pelos ganhos derivados dos fluxos inversos ${ }^{110}$. Para equilibrar essa situação, fez-se necessária a previsão de cláusulas de matching credit nos acordos de bitributação celebrados entre países desenvolvidos e em desenvolvimento.

Em texto sobre o assunto, Hope Ashiabor descreve duas situações de crédito fixado previamente: na primeira, o crédito a ser concedido pelo Estado da residência corresponde às alíquotas máximas para tributação na fonte previstas no acordo de bitributação; na segunda, o crédito corresponde a alíquotas superiores aos limites da tributação na fonte previstos no acordo de bitributação. No entendimento do autor, somente a segunda hipótese corresponderia ao matching credit $^{111}$.

Não partilhamos deste posicionamento, já que o traço distintivo do matching credit não é o percentual do crédito de imposto previsto, e sim o fato de ele ser fixado previamente, no próprio acordo de bitributação, e em total desvinculação ao nível de tributação no Estado da fonte ${ }^{112}$.

O termo tax sparing é geralmente utilizado nos países de common law para se referir às duas formas de alívio da dupla tributação aqui estudadas ${ }^{113}$. A OCDE entende que o matching credit é uma das formas pelas quais o mecanismo do tax sparing pode ser aplicado. De fato, no parágrafo 74 dos Comentários da OCDE ao artigo 23 da Convenção Modelo $^{114}$, está estabelecido que as provisões de tax sparing podem ter diferentes formas,

${ }^{110}$ Cf. Luís Eduardo Schoueri. Normas tributárias indutoras e intervenção econômica. Rio de Janeiro: Forense, 2005, p. 218.

${ }^{111}$ Cf. Hope Ashiabor, op. cit. (nota 41), pp. 81-83.

${ }^{112}$ Cf. Alexander J. Easson, op. cit. (nota 99), p. 520.

${ }^{113}$ Cf. IBFD, op. cit. (nota 13), p. 432.

${ }^{114} \mathrm{Cf}$. Comentários à Convenção Modelo da OCDE, artigo 23, parágrafo 74:

"74. Tax sparing provisions constitute a departure from the provisions of Articles 23 A and 23 B. Tax sparing provisions may take different forms, as for example:

(a) the State of residence will allow as a deduction the amount of tax which the State of source could have imposed in accordance with its general legislation or such amount as limited by the Convention (e.g. 
como, por exemplo, a dedução de um crédito, pelo Estado da residência, em parte fictício, fixado em um alíquota maior do que a efetivamente cobrada pelo Estado da fonte ${ }^{115}$.

O entendimento da OCDE a respeito do matching credit, que, apesar de não ter sido mencionado expressamente, foi descrito como um crédito "em parte fictício", poderia levar à apressada conclusão de que o matching credit requer, necessariamente, alguma tributação no Estado da fonte para que possa ser aplicado.

No entanto, tal assertiva não corresponde ao efetivo funcionamento do mecanismo do matching credit, que consiste pura e simplesmente na determinação, no texto do próprio acordo de bitributação, do montante do crédito a ser conferido pelo Estado da residência sobre determinados rendimentos, geralmente superior ao limite de tributação previsto neste mesmo acordo para tal rendimento, sendo indiferente para o Estado da residência como se deu a tributação no Estado da fonte, ou mesmo se ela efetivamente ocorreu. Havendo algum incentivo fiscal no Estado da fonte, o qual sequer será investigado, o benefício para o contribuinte será ainda maior ${ }^{116}$.

Corroborando tal entendimento, Luís Eduardo Schoueri ${ }^{117}$ ensina, a respeito do matching credit, que este independe das medidas unilaterais do Estado da fonte, possuindo um perfil pragmático, uma vez que as partes não precisam comprovar o nível da tributação na fonte, o qual é absolutamente irrelevante para fins de determinação do montante do crédito a ser compensado no Estado da residência.

Destarte, nota-se que o mecanismo de matching credit, por sua natureza, independente de qualquer consideração do Estado da residência quanto à tributação e à legislação do Estado da fonte.

limitations of rates provided for dividends and interest in Articles 10 and 11) even if the State of source has waived all or part of that tax under special provisions for the promotion of its economic development;

(b) as a counterpart for the tax reduction by the State of source the State of residence agrees to allow a deduction against its own tax of an amount (in part fictitious) fixed at a higher rate;

(c) the State of residence exempts the income which has benefited from tax incentives in the State of source."

${ }^{115}$ Assim, quando se for comentar no presente trabalho a posição da OCDE, a menção ao tax sparing implica menção ao matching credit.

${ }^{116}$ Cf. Hope Ashiabor, op. cit. (nota 41), p. 83.

${ }^{117}$ Cf. Luís Eduardo Schoueri, op. cit. (nota 40), p. 98. 


\subsubsection{Tax sparing $e$ matching credit: semelhanças $e$ diferenças}

Tanto o tax sparing quanto o matching credit são mecanismos que têm por objetivo atrair investimentos estrangeiros aos países em desenvolvimento. Com efeito, conforme relata Roberto França de Vasconcellos, a ideia comum aos dois conceitos é a de que poderá o contribuinte aproveitar-se de um crédito de imposto, no Estado da residência, como se o Estado da fonte não houvesse reduzido sua tributação ou oferecido qualquer vantagem para atrair o investimento de tal contribuinte ${ }^{118}$.

Klaus Vogel afirma que o matching credit corresponde a uma isenção parcial, concedida pelo Estado da residência, ao rendimento auferido no Estado da fonte. $\mathrm{Na}$ visão do autor, o Estado da residência não abre mão da totalidade do seu direito à tributação mundial sobre os rendimentos auferidos pelo seu residente no exterior, mas apenas de uma porcentagem deste, previamente fixada no acordo de bitributação ${ }^{119}$.

Parece-nos que também o tax sparing pode ser considerado uma modalidade de isenção parcial do imposto auferido no exterior ${ }^{120}$, tendo como principal diferença o fato de que, nesse caso, a parcela isenta no Estado da residência não está delimitada no acordo de bitributação, dependendo da legislação interna do Estado da fonte.

Em verdade o matching credit difere do tax sparing sob o aspecto da técnica aplicada, sendo o primeiro uma "prefixação do crédito de imposto sob um determinado percentual, inscrito na cláusula convencional", e o último "um mecanismo segundo o qual o Estado da fonte faz declarar os impostos que teriam sido pagos caso não existisse qualquer benefício"121.

No mesmo sentido, ao tratar das diferenças entre as duas modalidades de crédito (tax sparing e matching credit), leciona Alberto Xavier que a cláusula de matching credit atribui, no Estado da residência, o direito à dedução de um crédito fixado a forfait, que

\footnotetext{
${ }^{118}$ Cf. Roberto França de Vasconcellos, op. cit. (nota 22), p. 174. No mesmo sentido, cf. Claudio Sacchetto, op. cit. (nota 66), p. 81.

${ }^{119} \mathrm{Na}$ hipótese de o montante do crédito fixado no acordo de bitributação e o imposto devido no Estado da residência se igualarem, será o caso de isenção total. Cf. Klaus Vogel, op. cit. (nota 103), p. 1.256.

${ }^{120}$ Cf. IBFD, op. cit. (nota 13), p. 432.

${ }^{121}$ Cf. Heleno Taveira Torres, op. cit. (nota 3), p. 318.
} 
independe da política fiscal do Estado da fonte (o qual poderá ou não estabelecer redução de imposto ou até uma isenção) ${ }^{122}$.

Desta forma, a principal diferença entre as cláusulas de tax sparing e matching credit reside no fato de que, no matching credit, o benefício não está ligado ao nível de tributação no Estado da fonte, tampouco a qualquer redução no tributo que ali possa ter ocorrido $^{123}$.

\subsubsection{Histórico das cláusulas de tax sparing $e$ matching credit}

A primeira referência que se encontra ao tax sparing na literatura remete ao relatório de 1953 da British Royal Commission sobre tributação da renda, mencionado por Stanley S. Surrey em seu pronunciamento perante o Senado norte-americano, em 1957, por ocasião das discussões que envolveram o Acordo Estados Unidos-Paquistão ${ }^{124}$.

Em tal relatório, a British Royal Commission foi instada a analisar a pertinência da concessão de auxílio aos investimentos britânicos no exterior que tivessem sido beneficiados por incentivos fiscais ${ }^{125}$.

Propunha-se o estudo de tal questão, sobretudo, com relação às colônias britânicas no exterior, mas a British Royal Commission acabou por estender sua análise aos rendimentos auferidos no exterior por residentes do Reino Unido, de modo geral ${ }^{126}$.

No mencionado relatório, a British Royal Commission reconheceu que a política britânica de tributação dos rendimentos auferidos no exterior por seus residentes acabava por frustrar incentivos fiscais concedidos por países estrangeiros com a finalidade de fomentar seu desenvolvimento econômico ${ }^{127}$.

\footnotetext{
${ }^{122}$ Cf. Alberto Xavier, op. cit. (nota 5), p. 824.

123 Cf. IBFD, op. cit. (nota 13), p. 432.

${ }^{124}$ Cf. UNITED STATES SENATE. Double Taxation Convention with Pakistan: Hearing Before the Senate Committee on Foreign Relations. $85^{\text {th }}$ Congress, $1^{\text {st }}$ Session. Washington: United States Government Printing Office, 1957, pp. 7-8.

${ }^{125}$ Cf. Kim Brooks, op. cit. (nota 48), pp. 515-516.

${ }^{126}$ Cf. Kim Brooks, op. cit. (nota 48), pp. 515-516.

${ }^{127}$ Cf. Kim Brooks, op. cit. (nota 48), p. 516.
} 
Assim, entendeu-se ser necessário levar em conta os incentivos fiscais concedidos no exterior por duas razões principais. A primeira consistia na responsabilidade do Reino Unido pelo desenvolvimento econômico de suas colônias. Em segundo lugar, alegou-se que se o problema não fosse enfrentado adequadamente, haveria um possível risco às relações exteriores do Reino Unido ${ }^{128}$.

Conclui-se, desta forma, que os tratados bilaterais seriam os instrumentos apropriados para a preservação dos incentivos fiscais concedidos no exterior em favor dos residentes britânicos, surgindo aí o conceito de tax sparing ${ }^{129}$, que correspondia ao crédito relativo aos tributos que deixaram de ser cobrados (taxes spared) pelos países em desenvolvimento em virtude de programas de incentivo ao investimento estrangeiro, destinados a promover o desenvolvimento industrial, comercial, científico e educacional, entre outros ${ }^{130}$.

O Parlamento discutiu essa proposição por duas vezes, em 1953 e em 1956, até que, em 1957, esta foi finalmente rejeitada. Em 1953, debatia-se se as cláusulas de tax sparing deveriam limitar-se às colônias, ou também ser estendidas a outros países em grau de desenvolvimento econômico inferior. Os debates de 1956, por outro turno, giravam em torno de questões como o sacrifício de receitas a ser suportado pelo Reino Unido, apoio ao desenvolvimento econômico das colônias britânicas e a potencial perda de competitividade das empresas britânicas no exterior, se outros países, tal como os Estados Unidos, viessem a tomar medidas similares para a proteção dos incentivos fiscais concedidos pelas colônias do Reino Unido ${ }^{131}$.

Tal rejeição não pôs fim aos debates em torno do tax sparing pelas autoridades britânicas, de tal sorte que em 1961 foi ratificado o acordo de bitributação entre Reino Unido e Paquistão, contendo a referida cláusula ${ }^{132}$.

O Acordo Reino Unido-Paquistão não foi o primeiro a ser aprovado com o tax sparing, haja vista que em 1959 foram ratificados o Acordo Alemanha-Índia e o Acordo Suécia-Israel, ambos prevendo tal mecanismo ${ }^{133}$.

\footnotetext{
${ }^{128}$ Cf. Kim Brooks, op. cit. (nota 48), p. 516.

${ }^{129}$ Cf. Kim Brooks, op. cit. (nota 48), p. 516; OCDE, op. cit. (nota 1), p. 15.

${ }^{130}$ Cf. OCDE, op. cit. (nota 1), p. 15.

${ }^{131}$ Cf. Kim Brooks, op. cit. (nota 48), p. 517.

${ }^{132}$ Cf. Kim Brooks, op. cit. (nota 48), p. 517.

${ }^{133}$ Cf. Kim Brooks, op. cit. (nota 48), p. 517.
} 
De qualquer forma, o tax sparing foi incluído pela primeira vez no já mencionado acordo celebrado entre Estados Unidos e Paquistão, em $1957^{134}$. Após muitos debates no Senado dos Estados Unidos, o referido acordo foi aprovado, mas sem a cláusula de tax sparing, uma vez que o benefício fiscal em que esta se baseava não mais estava vigente no Paquistão.

Apesar de esta ter sido a justificativa oficial para a não inclusão do tax sparing no Acordo Estados Unidos-Paquistão, é certo que a posição norte-americana ${ }^{135}$, contrária à adoção das cláusulas de tax sparing, naquele momento se firmou, sendo mantida até o presente.

Independentemente do entendimento manifestado pelos Estados Unidos, é certo que, nas décadas de 1960 e 1970, diversos acordos de bitributação celebrados entre países desenvolvidos e países em desenvolvimento continham cláusulas de $\operatorname{tax}_{\text {sparing }}{ }^{136}$, muitas das quais inspiradas no tax sparing formulado para o Acordo Estados Unidos-Paquistão ou sendo, por vezes, ainda mais abrangentes ${ }^{137}$.

Nesse passo, em diversos acordos dessa época foram incluídos dispositivos específicos que permitiam a continuidade do tax sparing mesmo na hipótese em que o incentivo fiscal concedido pelo Estado da fonte sofresse algumas modificações ${ }^{138}$.

É o caso do já mencionado Acordo Reino Unido-Paquistão, ratificado em 1961, no qual se esclarecia que o tax sparing continuaria a ser aplicado se houvesse modificações menores no incentivo fiscal subjacente. Nesse mesmo acordo de bitributação previa-se, também, que a cláusula de tax sparing poderia ser estendida a medidas de incentivo subsequentes que fossem substancialmente similares.

Aponta-se como outro desenvolvimento verificado no período a inclusão, em diversos acordos de bitributação, de cláusulas de matching credit, pelas quais o percentual do imposto considerado como pago no Estado da fonte era estabelecido no texto do próprio acordo, de forma prévia. Nesse sentido, podem ser mencionados o Acordo Alemanha-

${ }^{134}$ Cf. Kim Brooks, op. cit. (nota 48), p. 518. A cláusula de tax sparing do Acordo Estados UnidosPaquistão, bem como as discussões que a envolveram e culminaram na sua rejeição, serão analisados em maiores detalhes em tópico posterior do presente trabalho.

135 A política norte-americana relativa às cláusulas de tax sparing será analisada adiante, em seus pormenores.

${ }^{136}$ Cf. Cristiane Coelho, op. cit. (nota 73), pp. 687-688.

${ }^{137}$ Cf. OCDE, op. cit. (nota 1), p. 16.

${ }^{138}$ Cf. OCDE, op. cit. (nota 1), p. 16. 
Indonésia, de 1977, e o Acordo Brasil-Japão, de 1976, sendo que neste último o matching credit foi previsto no protocolo ${ }^{139}$.

Também foram introduzidas limitações temporais para a aplicação das cláusulas de tax sparing, limitações estas que poderiam ser, essencialmente, de dois tipos: (i) limitação da aplicação dos benefícios do tax sparing a um período determinado, em relação a uma fonte em particular (como no caso do Acordo Reino Unido-Indonésia, de 1974); e (ii) limitação dos efeitos da cláusula de tax sparing em virtude de sua expiração em um determinado momento (sunset clause ${ }^{140}$ ), ou pela determinação de uma revisão obrigatória (como é o caso do Acordo Austrália-Singapura, de 1969, que expiraria em 1974, não fosse o acordado entre os Estados contratantes). As sunset clauses tornaram-se mais comuns em meados dos anos $1980^{141}$.

Após ampla adoção das cláusulas de tax sparing nos acordos de bitributação, os países desenvolvidos estão revendo o seu posicionamento, aparentemente motivados pela publicação do já mencionado Relatório da OCDE, em 1998. Este assunto será discutido em maiores detalhes no próximo capítulo.

\subsection{Interpretação das cláusulas de tax sparing e matching credit}

\subsubsection{Consideraçães gerais sobre a interpretação dos acordos de bitributação}

A interpretação dos tratados internacionais é regida pelo Direito Internacional Público e, sobretudo, pelos artigos 31 a 33 da Convenção de Viena sobre o Direito dos Tratados ("Convenção de Viena"), de 23 de maio de 1969, que entrou em vigor em 27 de janeiro de 1980 (quando foi ratificada pelo $35^{\circ}$ país signatário) ${ }^{142}$ e foi promulgada no Brasil pelo Decreto $n^{\circ} 7.030 / 09$.

\footnotetext{
${ }^{139}$ Cf. OCDE, op. cit. (nota 1), pp. 16-17.

${ }^{140}$ Cf. J. David B. Oliver. “Tax Sparing”. Intertax. v. 26, n. 6-7, 1998, p. 190.

${ }^{141}$ Cf. OCDE, op. cit. (nota 1), p. 17.

142 Cf. Klaus Vogel e Rainer G. Prokisch. "General report". Cahiers de Droit Fiscal International. Interpretation of double taxation conventions. v. LXXVIIIa. Deventer: Kluwer Law and Taxation, 1993, p. 66.
} 
Ainda que a Convenção de Viena apenas tenha sido ratificada, aprovada e promulgada pelo Brasil em 2009, deve-se reconhecer que tal instrumento codifica regras consuetudinárias de Direito Internacional, de modo que sua aplicação independe da ratificação por um determinado Estado ${ }^{143}$.

Cabe ao artigo 31 da Convenção de Viena ${ }^{144}$ estabelecer as regras gerais de interpretação dos tratados internacionais. Assim é que se determina, no artigo 31(1), que um tratado internacional deve ser interpretado de boa fé, de acordo com o sentido comum que se atribui aos termos ali adotados, em seu contexto e à luz de seu objetivo e finalidade.

O parágrafo $2^{\circ}$ do artigo 31 , por seu turno, atende ao propósito de explicar o que se deve entender por contexto, o qual abarca, além do texto do tratado internacional, seu preâmbulo e anexos, qualquer acordo ou instrumento relativo estabelecido em conexão com a conclusão do tratado, e que com este tenha relação.

Na sequência, o artigo 31 (3) esclarece que, juntamente com o contexto, devem ser considerados quaisquer acordos posteriores entre as partes relativos à interpretação ou aplicação do tratado, qualquer prática seguida posteriormente na aplicação do tratado, pela qual as partes estabeleçam um acordo concernente à sua interpretação, bem como quaisquer regras de Direito Internacional aplicáveis às relações entre as partes. Já o artigo 31(4) determina que um termo será entendido em seu sentido especial na hipótese de ser essa a intenção das partes.

${ }^{143}$ Cf. Chris Finnerty et al., op. cit. (nota 6), p. 17; Sergio André Rocha, op. cit. (nota 23), pp. 97-99; Daniel Vitor Bellan. Direito tributário internacional: rendimentos de pessoas físicas nos tratados internacionais contra a dupla tributação. São Paulo: Saraiva, 2010, pp. 58-59.

144 "Artigo 31

Regra Geral de Interpretação

1. Um tratado deve ser interpretado de boa fé segundo o sentido comum atribuível aos termos do tratado em seu contexto e à luz de seu objetivo e finalidade.

2. Para os fins de interpretação de um tratado, o contexto compreenderá, além do texto, seu preâmbulo e anexos:

a) qualquer acordo relativo ao tratado e feito entre todas as partes em conexão com a conclusão do tratado;

b) qualquer instrumento estabelecido por uma ou várias partes em conexão com a conclusão do tratado e aceito pelas outras partes como instrumento relativo ao tratado.

3. Serão levados em consideração, juntamente com o contexto:

a) qualquer acordo posterior entre as partes relativo à interpretação do tratado ou à aplicação de suas disposições;

b) qualquer prática seguida posteriormente na aplicação do tratado, pela qual se estabeleça o acordo das partes relativo à sua interpretação;

c) quaisquer regras pertinentes de Direito Internacional aplicáveis às relações entre as partes.

4. Um termo será entendido em sentido especial se estiver estabelecido que essa era a intenção das partes." 
$\mathrm{O}$ artigo $32^{145}$, de outra parte, apresenta os chamados meios suplementares de interpretação, utilizados com o fim de complementar a interpretação conferida ao tratado internacional de acordo com os princípios expostos no artigo 31, confirmando-a ou esclarecendo-a (mas não a corrigindo ${ }^{146}$ ). São eles, por exemplo, os trabalhos preparatórios dos tratados e as circunstâncias em que se deu sua conclusão, os quais estão referidos no texto do artigo 31 da Convenção de Viena, de forma não exaustiva ${ }^{147}$.

Por fim, o artigo $33^{148}$ clarifica que, na hipótese de um determinado tratado ser autenticado em dois ou mais idiomas, o texto terá igualmente fé em cada um deles, salvo concordância das partes no sentido de que, havendo divergência, o texto escrito em um determinado idioma deverá prevalecer.

Muito se discute, na seara da interpretação dos acordos internacionais em matéria tributária, a respeito do papel dos Comentários à Convenção Modelo da OCDE. Questionase, assim, se tal documento deve ser entendimento como "sentido comum", nos termos do artigo 31(1) da Convenção de Viena, como "sentido especial", tal como disposto no artigo 31(4), ou mesmo como um dos "meios suplementares de interpretação" disponíveis, na esteira do artigo $32^{149}$.

Com efeito, ao tratar dos relatórios apresentados por diversos especialistas de todo o mundo por ocasião do $47^{\circ}$ Congresso da International Fiscal Association (IFA), realizado em Florença, em 1993, Klaus Vogel e Rainer Prokisch apontavam a falta de uniformidade que haviam encontrado quanto à natureza dos Comentários à Convenção

145 “Artigo 32

Meios Suplementares de Interpretação

Pode-se recorrer a meios suplementares de interpretação, inclusive aos trabalhos preparatórios do tratado e às circunstâncias de sua conclusão, a fim de confirmar o sentido resultante da aplicação do artigo 31 ou de determinar o sentido quando a interpretação, de conformidade com o artigo 31:

a) deixa o sentido ambíguo ou obscuro; ou

b) conduz a um resultado que é manifestamente absurdo ou desarrazoado."

${ }^{146}$ Cf. Klaus Vogel e Rainer G. Prokisch, op. cit. (nota 142), p. 74.

${ }^{147}$ Cf. Klaus Vogel e Rainer G. Prokisch, op. cit. (nota 142), p. 74.

148 "Artigo 33

Interpretação de Tratados Autenticados em Duas ou Mais Línguas

1. Quando um tratado foi autenticado em duas ou mais línguas, seu texto faz igualmente fé em cada uma delas, a não ser que o tratado disponha ou as partes concordem que, em caso de divergência, prevaleça um texto determinado.

2. Uma versão do tratado em língua diversa daquelas em que o texto foi autenticado só será considerada texto autêntico se o tratado o previr ou as partes nisso concordarem.

3. Presume-se que os termos do tratado têm o mesmo sentido nos diversos textos autênticos.

4. Salvo o caso em que um determinado texto prevalece nos termos do parágrafo 1, quando a comparação dos textos autênticos revela uma diferença de sentido que a aplicação dos artigos 31 e 32 não elimina, adotar-se-á o sentido que, tendo em conta o objeto e a finalidade do tratado, melhor conciliar os textos."

${ }^{149}$ Cf. Chris Finnerty et al., op. cit. (nota 6), p. 18. 
Modelo da OCDE: estes eram referidos como guidelines, auxiliares interpretativos, parte do contexto ${ }^{150}$ ou meios suplementares de interpretação ${ }^{151}$.

Tal assunto tem sido debatido com bastante densidade na doutrina, fugindo ao escopo do presente trabalho aprofundá-lo nos pormenores que a matéria merece. Até mesmo porque são inúmeras as variáveis que devem ser analisadas ao se tratar deste tema, as quais podem envolver Estados membros, Estados não membros, comentários existentes no momento da celebração do tratado, comentários posteriores, reservas e posições assumidas pelos Estados não membros etc ${ }^{152}$.

Nesse passo, na hipótese em que dois Estados membros da OCDE celebram acordo de bitributação nos exatos termos da Convenção Modelo da OCDE, presume-se que estes pretendem adotar suas recomendações ${ }^{153}$.

No entanto, cumpre ressaltar que, embora tenha por prática adotar como base a Convenção Modelo da OCDE ao negociar seus acordos de bitributação ${ }^{154}$, o Brasil não é um Estado membro da OCDE, de modo que os Comentários à Convenção Modelo desta entidade certamente adquirem menor relevância ${ }^{155}$, não se revestindo de caráter vinculante na interpretação dos acordos de bitributação celebrados pelo País ${ }^{156}$.

De qualquer forma, mesmo para Estados não membros, como é o caso do Brasil, não se pode negar a importância dos Comentários à Convenção Modelo da OCDE como obra de referência a ser adotada na interpretação dos acordos de bitributação ${ }^{157}$.

Também merece destaque, quando se trata da interpretação dos acordos de bitributação, o artigo 3(2) da Convenção Modelo da $\mathrm{OCDE}^{158}$, o qual, por fazer remissão à

\footnotetext{
${ }^{150}$ Em sentido contrário, defendendo que os Comentários da OCDE não podem ser entendidos como "contexto", nos termos da Convenção de Viena, mas apenas como um elemento interpretativo a ser considerado pelo intérprete, cf. Sergio André Rocha, op. cit. (nota 23), pp. 156-157.

${ }^{151}$ Cf. Klaus Vogel e Rainer G. Prokisch, op. cit. (nota 142), p. 64.

${ }^{152}$ Cf. Chris Finnerty et al., op. cit. (nota 6), p. 19; Daniel Vitor Bellan, op. cit. (nota 143), pp. 89-102.

${ }^{153}$ Cf. Klaus Vogel. "Double tax treaties and their interpretation". International Tax \& Business Lawyer. ano 1. v. 4, 1986, p. 41.

${ }^{154}$ O Brasil e a maioria dos países latino-americanos celebram seus acordos de bitributação com base na Convenção Modelo da OCDE. Cf. Cristiane Coelho. "Interpretação dos tratados internacionais em matéria tributária: doutrina e prática na América Latina”. TORRES, Heleno Taveira (coord.). Direito Tributário e Ordem Econômica: Homenagem aos 60 anos da ABDF. São Paulo: Quartier Latin, 2010, p. 704.

${ }^{155}$ Cf. Klaus Vogel, op. cit. (nota 153), p. 42.

${ }^{156}$ Cf. Daniel Vitor Bellan, op. cit. (nota 143), p. 95.

${ }^{157}$ Cf. Daniel Vitor Bellan, op. cit. (nota 143), p. 96.

158 "Article 3
} 
legislação interna do Estado contratante que aplique o tratado, é conhecido como cláusula de reenvio (general renvoi clause).

O conteúdo do artigo 3(2) está presente na maioria dos acordos de bitributação celebrados pelo Brasil. Trata-se de uma regra geral de interpretação dos termos utilizados no acordo, mas que nele não estejam definidos.

Conforme o referido dispositivo, para fins de aplicação do acordo de bitributação em dado momento por um Estado contratante, qualquer termo ou expressão que nele não se encontrem definidos terá, a não ser que seu contexto exija uma interpretação diferente, o significado que nesse momento lhe for atribuído pela legislação desse Estado relativa aos impostos que são objeto da Convenção, prevalecendo o significado atribuído pela legislação tributária aplicável nesse Estado sobre o significado atribuído por outras leis desse Estado.

Destarte, diante de termos utilizados no acordo de bitributação, mas não definidos em seu texto, buscar-se-á na legislação tributária interna do Estado que está aplicando o acordo, relativa aos impostos que são objeto do acordo ${ }^{159}$, o seu significado, o qual será adotado, a menos que o contexto requeira interpretação diversa ${ }^{160}$.

Muitos autores defendem a posição de que a cláusula de reenvio ao direito interno deve ser utilizada como ultima ratio interpretativa, i.e., quando o termo não estiver definido no texto do acordo de bitributação e, além disso, o contexto também não indique solução diversa. Seria o artigo 3(2) da Convenção Modelo entendido, nestes termos, como subsidiário, haja vista os alegados riscos de reenvio constante das matérias não definidas no acordo de bitributação ao direito interno ${ }^{161}$.

(...)

2. As regards the application of the Convention at any time by a Contracting State, any term not defined therein shall, unless the context otherwise requires, have the meaning that it has at that time under the law of that State for the purposes of the taxes to which the Convention applies, any meaning under the applicable tax laws of that State prevailing over a meaning given to the term under other laws of that State."

${ }^{159}$ O que implica dizer que o artigo 3(2) da Convenção Modelo da OCDE não trata de reenviar o intérprete, de forma genérica, à legislação interna do Estado que estiver aplicando o acordo de bitributação, mas somente à legislação tributária e, mais especificamente, às leis que tratem dos impostos sobre a renda e o capital abrangidos pelo acordo. Cf. Alberto Xavier, op. cit. (nota 5), p. 187.

${ }^{160}$ Cf. Klaus Vogel e Rainer G. Prokisch, op. cit. (nota 142), pp. 81-82.

${ }^{161}$ Cf. Alberto Xavier, op. cit. (nota 5), pp. 186-187; Sergio André Rocha, op. cit. (nota 23), pp. 146-147; Heleno Taveira Torres, op. cit. (nota 3), p. 640; Flávio Garcia Cabral. "Interpretação e aplicação dos tratados contra a pluritributação internacional". Revista Tributária e de Finanças Públicas. ano 20. v. 105. julho/agosto, 2012, pp. 96-97. 
Diverso é o entendimento de Klaus Vogel, para quem não é esse o sentido que deve ser extraído do artigo 3(2) da Convenção Modelo da OCDE. De acordo com o autor, na aplicação do mencionado dispositivo, a adoção de uma interpretação que contrarie a legislação interna deverá ser excepcional, de modo que somente argumentos relativamente fortes baseados no contexto poderão ser aceitos como forma de se negar a interpretação conferida pela lei interna (ainda que esta venha a conduzir, por exemplo, a uma situação de dupla tributação ou dupla não tributação) ${ }^{162}$. A referência à lei tributária do Estado contratante que aplica o acordo não seria, desta forma, meramente subsidiária ${ }^{163}$.

Contudo, ainda que não adote a ideia de que a interpretação segundo o contexto deva prevalecer, Klaus Vogel defende que o termo "contexto" deverá ser interpretado da maneira mais ampla possível, incluindo-se nele até mesmo a história e o desenvolvimento do acordo. Trata-se, assim, de conceito mais abrangente do que aquele expresso no artigo 31(2) da Convenção de Viena ${ }^{164}$.

Intrincada questão é a de saber a que Estado contratante cabe a "aplicação" do acordo, tal como definido no artigo 3(2). Conforme relatado por Klaus Vogel, John Avery Jones (com o International Tax Group) entende que cabe ao Estado da fonte aplicar o acordo de bitributação, sendo as qualificações efetuadas por este efetuadas são vinculantes para o Estado da residência ${ }^{165}$. Tal entendimento ficou posteriormente conhecido como new approach da OCDE, o qual atribui a competência qualificatória dos rendimentos ao Estado da fonte, baseando-se em interpretação do artigo 23 da Convenção Modelo.

Klaus Vogel discorda dessa afirmação, por entender que também o Estado da residência atua aplicando o acordo de bitributação - quando isenta um rendimento, em razão do quanto disposto nas regras distributivas, ou mesmo quando, ao isentar um rendimento ou conceder um crédito de imposto nos termos do artigo 23 da Convenção Modelo da OCDE, relativo aos métodos para evitar a dupla tributação, examina se o Estado da fonte efetivamente estava autorizado a tributar o referido rendimento ${ }^{166}$.

\footnotetext{
${ }^{162}$ Cf. Klaus Vogel, op. cit. (nota 153), p. 74.

${ }^{163}$ Cf. Klaus Vogel e Rainer G. Prokisch, op. cit. (nota 142), pp. 81-82.

164 Cf. Klaus Vogel, op. cit. (nota 153), p. 74. Em sentido contrário, entendendo que o termo "contexto" referido no artigo 3(2) da Convenção Modelo da OCDE deve ter o mesmo significado expresso no artigo 31 da Convenção de Viena, cf. Daniel Vitor Bellan, op. cit. (nota 143), p. 81.

${ }^{165}$ Cf. Klaus Vogel, op. cit. (nota 153), p. 71.

${ }^{166}$ Cf. Klaus Vogel, op. cit. (nota 153), p. 71.
} 
Outra discussão que emerge da análise do artigo 3(2) da Convenção Modelo da OCDE diz respeito a qual legislação deverá ser considerada, se aquela vigente no momento da celebração do acordo de bitributação (interpretação estática ou static meaning) ou a do momento da aplicação do acordo (interpretação dinâmica ou ambulatory meaning) ${ }^{167}$.

A interpretação dinâmica, adotada pela OCDE nos Comentários à Convenção Modelo, é frequentemente entendida como a mais recomendável, na medida em que asseguraria a longevidade dos acordos de bitributação, os quais seriam mais efetivos se, ao longo do tempo, pudessem incorporar alterações verificadas na legislação interna. Nada obstante, a interpretação dinâmica deve ser adotada com a devida ponderação, evitando-se assim que as bases da celebração do acordo sejam alteradas de modo significativo em decorrência de alterações na legislação interna ${ }^{168}$.

Feitos estes breves comentários acerca da interpretação dos acordos de bitributação, que de maneira alguma têm a pretensão de esgotar matéria tão extensa e complexa, passase a tratar da interpretação a ser conferida às cláusulas de tax sparing e matching credit.

\subsubsection{Interpretação das cláusulas de tax sparing $e$ matching credit}

Feitas estas breves considerações sobre a interpretação dos acordos de bitributação, passa-se a tratar, de forma específica, de considerações relativas à interpretação das cláusulas de tax sparing e matching credit.

Conforme assevera Daniel Vitor Bellan, a referência ao contexto na interpretação dos acordos internacionais no termos da Convenção de Viena demonstra que este diploma acabou por prestigiar a adoção de uma interpretação sistemática ${ }^{169}$.

Nesse sentido mesmo, Sergio André Rocha afirma que, na interpretação dos acordos de bitributação, deve-se levar em conta os interesses que se buscou tutelar, bem

\footnotetext{
${ }^{167}$ Cf. Klaus Vogel e Rainer G. Prokisch, op. cit. (nota 142), p. 80.

${ }^{168}$ Cf. Klaus Vogel e Rainer G. Prokisch, op. cit. (nota 142), p. 80.

${ }^{169}$ Cf. Daniel Vitor Bellan, op. cit. (nota 143), 2010, p. 62.
} 
como as finalidades que se buscou alcançar, além dos valores que fundamentam a norma, o histórico em que se deu sua edição e o contexto em que esta se encontra inserida ${ }^{170}$.

De fato, é o que se extrai do já mencionado artigo 31(1) da Convenção de Viena, que esclarece que um tratado internacional deve ser interpretado "de boa fé segundo o sentido comum atribuível aos termos do tratado em seu contexto e à luz de seu objetivo e finalidade".

No presente capítulo, foram discutidos os diversos objetivos e finalidades atribuídos aos acordos de bitributação. Cumpre esclarecer, dentre tais objetivos, quais correspondem aos do tax sparing e do matching credit, para fins de se determinarem os limites interpretativos que devem ser adotados quando da análise de tais cláusulas.

Em primeiro lugar, aponte-se que as cláusulas de tax sparing e de matching credit não atendem ao objetivo mais evidente dos acordos de bitributação, que é o de evitar a dupla imposição sobre a renda.

Assim, o argumento de que as cláusulas de tax sparing e matching credit são inócuas, haja vista que muitas vezes referem-se a situações em que não há bitributação porque houve isenção total do rendimento no Estado da fonte, por exemplo - deve ser desde já rechaçado ${ }^{171}$.

O combate há bitributação não é objetivo tutelado pelas cláusulas de tax sparing e matching credit, e sim pelas tradicionais formulações dos métodos da isenção e do crédito, previstos nos acordos de bitributação.

Portanto, considerações relativas ao combate à dupla tributação (ou à dupla não tributação) não são relevantes para fins de interpretação das cláusulas de tax sparing e matching credit, assim como não o são o combate à evasão fiscal e à discriminação.

Com efeito, tal como já mencionado, os acordos contra a dupla tributação possuem a finalidade de fomentar os investimentos e as relações comerciais entre os Estados contratantes, através da proteção da segurança jurídica dos investidores estrangeiros ${ }^{172}$.

\footnotetext{
${ }^{170}$ Cf. Sergio André Rocha, op. cit. (nota 23), p. 140.

${ }^{171}$ Cf. Harry A. Shannon III, op. cit. (nota 44), p. 88.

${ }^{172}$ Cf. Sergio André Rocha, op. cit. (nota 23), p. 49.
} 
Nesse sentido, note-se que Fernando Serrano Antón, citado por Sergio André Rocha, elenca dentro os objetivos dos acordos de bitributação o fomento aos investimentos estrangeiros, por meio de redução das retenções na fonte e da utilização das cláusulas de tax sparing e matching credit $^{173}$. Nathan Boidman vai além, entendendo que as cláusulas de tax sparing e matching credit correspondem a um objetivo autônomo dos acordos de bitributação $^{174}$.

Assim, entendemos que as cláusulas de tax sparing e matching credit devem ser interpretadas à luz de seu objetivo e finalidade, nos termos do artigo 31(1) da Convenção de Viena: o fomento aos investimentos entre os Estados contratantes, sobretudo aqueles destinados aos países em desenvolvimento. Esta é a pedra mestra interpretativa que guiará este trabalho e permeará as conclusões que se julga adequadas sobre a aplicação das cláusulas em comento.

\footnotetext{
${ }^{173}$ Cf. Sergio André Rocha, op. cit. (nota 23), p. 43.

${ }^{174}$ Cf. Nathan Boidman. "Canada: some current issues with treaty tax-sparing provisions". Bulletin for International Taxation. agosto/setembro, 1985, p. 387.
} 


\section{A POSIÇÃO DA ONU E DA OCDE A RESPEITO DAS CLÁUSULAS DE TAX SPARING E MATCHING CREDIT}

\subsection{A posição da OCDE a respeito das cláusulas de tax sparing}

\subsubsection{As cláusulas de tax sparing nos Comentários à Convenção Modelo da OCDE}

Desde o fim da década de 1960 e do início da década de 1970, a maioria dos Estados membros da OCDE passou a adotar cláusulas de tax sparing em ao menos alguns dos seus acordos de bitributação assinados com países em desenvolvimento. Entendia-se que tais cláusulas faziam parte de uma política de auxílio internacional que visava a promover atividades comerciais, industriais e científicas nos países menos desenvolvidos ${ }^{175}$.

Nesse passo, deve-se notar que, nos Comentários ao artigo 23 da Convenção Modelo da OCDE de 1963, já se fazia referência ao tax sparing ${ }^{176}$. Em tal documento, reconhecia-se que os incentivos fiscais concedidos pelos países em condição de menor desenvolvimento, com a finalidade de atração de investimentos estrangeiros, eram anulados caso se reconhecesse como crédito apenas o montante do imposto efetivamente pago no Estado da fonte.

Assim, na hipótese de os Estados contratantes concordarem que os referidos incentivos fiscais não deveriam ser anulados, sugeria-se que esse problema poderia ser enfrentado através da isenção desses rendimentos no Estado da residência do investidor, ou através do tax sparing ${ }^{177}$.

Mencione-se que, nesse documento, não se fazia referência ao tax sparing, mas sim ao matching credit, como sendo o método pelo qual o Estado da residência permite que

\footnotetext{
${ }^{175}$ Cf. Deborah Toaze. "Tax sparing: good intentions, unintended results”. Canadian Tax Journal. v. 49, n. 4, 2001, p. 888.

${ }^{176}$ Cf. Comentários ao artigo 23 da Convenção Modelo da OCDE de 1963, parágrafos 47 a 51.

${ }^{177}$ Cf. Comentários ao artigo 23 da Convenção Modelo da OCDE de 1963, parágrafos 47 a 51.
} 
seja deduzido de seu imposto o montante correspondente ao imposto que teria sido pago no Estado da fonte na ausência de incentivos fiscais. O matching credit seria, assim, uma das formas possíveis de se tratar a questão da existência de tax-spared em razão de incentivos fiscais concedidos pelo Estado da fonte ${ }^{178}$.

Desta feita, nos Comentários ao artigo 23 da Convenção Modelo da OCDE, esclarecia-se que os Estados contratantes eram livres em suas negociações para acordarem acerca de desvios ao método do crédito ordinário, bem como de que forma e em que condições tais desvios deveriam ocorrer ${ }^{179}$.

Anos mais tarde, nos Comentários ao artigo 23 da Convenção Modelo de 1977, o problema da possibilidade de anulação dos incentivos fiscais concedidos pelo Estado da fonte quando da aplicação do método do crédito ordinário voltou a ser enfrentado.

Nesse passo, como forma de evitar tal efeito, são mencionadas as cláusulas de tax sparing, que consistem em uma derrogação do método do crédito ordinário. Conforme disposto pela OCDE, o mecanismo do tax sparing pode assumir diferentes formas, como as que seguem:

(i) O Estado da residência permite a dedução, como crédito, do imposto que teria sido pago no Estado da fonte, nos termos de sua legislação interna ou do limite previsto no acordo de bitributação, mesmo que o Estado da fonte tenha deixado de cobrar parte ou a totalidade do imposto, em razão de dispositivos legais destinados à promoção de seu desenvolvimento econômico;

(ii) O Estado da residência permite que se deduza, como crédito, um montante (parcialmente fictício) determinado a uma alíquota superior, como contrapartida a uma redução na tributação efetuada pelo Estado da fonte;

(iii) $\mathrm{O}$ Estado da residência isenta os rendimentos que se beneficiaram de incentivos fiscais no Estado da fonte.

O exemplo mencionado pela OCDE no item (i) corresponde ao tax sparing propriamente dito, i.e., o crédito no Estado da residência relativo ao montante do imposto que teria sido pago no Estado da fonte, não houvessem incentivos fiscais voltados à atração

\footnotetext{
${ }^{178}$ Cf. Comentários ao artigo 23 da Convenção Modelo da OCDE de 1963, parágrafos 47 a 51.

${ }^{179}$ Cf. Comentários ao artigo 23 da Convenção Modelo da OCDE de 1963, parágrafos 47 a 51.
} 
de investimentos estrangeiros, destinados à promoção do desenvolvimento econômico do Estado da fonte.

No item (ii), faz-se referência a uma forma de aplicação do tax sparing que mais se confundem com o matching credit, uma vez que o montante do crédito a ser concedido pelo Estado da residência seria fixado de forma prévia. No entanto, o mecanismo descrito diverge do matching credit tal como definido no presente trabalho.

Isso porque, diante da indicação de que o montante do crédito concedido pelo Estado da residência é parcialmente fictício, presume-se que o entendimento é o de que necessariamente terá havido alguma tributação no Estado da fonte, caso contrário o crédito poderia ser totalmente fictício. Além disso, esse mecanismo é entendido como uma contrapartida a uma redução na tributação pelo Estado da fonte.

Tal definição, em nosso entender, não corresponde ao matching credit, ainda que dele se aproxime. Isso porque, na concessão do matching credit, é absolutamente irrelevante qualquer análise voltada à legislação interna do Estado da fonte. Não se questiona, assim, a existência ou não de incentivos fiscais, ou mesmo a ocorrência de qualquer tributação pelo Estado da fonte.

Por fim, a hipótese descrita no item (iii) corresponde, na realidade, à aplicação pura e simples do método da isenção. Sua indicação pela OCDE não é despropositada, na medida em que o tax sparing e o matching credit são, em si mesmos, uma forma de isenção, seja total ou parcial, da tributação no Estado da residência.

Considerando-se os Comentários às Convenções Modelo da OCDE de 1963 e de 1977, nota-se que a Organização sempre adotou postura relutante com relação ao tax sparing. Embora a adoção de tais cláusulas fosse sugerida em determinadas circunstâncias, não houve de fato uma campanha em favor do tax sparing, que já era amplamente adotado por vários Estados membros da $\mathrm{OCDE}^{180}$.

Credita-se tal relutância ao fato de que muitos dos Estados membros da OCDE isentam rendimentos auferidos no exterior, de modo que o tax sparing torna-se irrelevante, bem como à firme posição contrária dos Estados Unidos com relação à adoção do mecanismo em tela e também ao fato de que os interesses dos países em desenvolvimento

${ }^{180}$ Cf. Kim Brooks, op. cit. (nota 48), p. 523. 
nunca foram seriamente considerados pela OCDE, cuja Convenção Modelo foi primordialmente modelada para aplicar-se em relações que envolvam dois países desenvolvidos $^{181}$.

Deve-se notar que, no ano 2000, em razão da publicação do relatório "Tax sparing: a reconsideration", os Comentários ao artigo 23 da Convenção Modelo da OCDE foram substancialmente modificados no que diz respeito ao tax sparing. Com isso, boa parte das críticas e objeções da Organização as cláusulas de tax sparing, constantes do mencionado relatório, foi incorporada aos Comentários ao artigo $23^{182}$.

Passa-se, assim, a discorrer a respeito das críticas tecidas pela OCDE, no referido relatório, relativamente à adoção das cláusulas de tax sparing.

\subsubsection{Críticas da $\mathrm{OCDE}$ à adoção das cláusulas de tax sparing: relatório "Tax sparing: a reconsideration"}

As cláusulas de tax sparing, cuja utilização já foi recomendada pela OCDE, ainda que com certa relutância, foram criticadas pela Organização em relatório publicado em 1998, denominado "Tax sparing: a reconsideration" (a que estamos nos referindo como "Relatório da OCDE”), o qual se baseia em estudos iniciados em $1997^{183}$.

Ainda que se alegue que a OCDE não buscou condenar o tax sparing nesse Relatório, mas apenas trazer recomendações quanto à sua adoção ${ }^{184}$, é certo que em tal documento foram diversas as objeções veiculadas pela Organização relativamente às cláusulas em tela.

\footnotetext{
${ }^{181}$ Cf. Kim Brooks, op. cit. (nota 48), p. 523.

${ }^{182}$ Cf. Comentários ao artigo 23 da Convenção Modelo da OCDE de 1977, parágrafos 75 a 78.

${ }^{183}$ Cf. Jeffrey Owens e Torsten Fensby, op. cit. (nota 92), p. 274.

${ }^{184}$ Nesse sentido, Damian Laurey afirma que o relatório da OCDE não buscou condenar o tax sparing, mas apenas prever regras gerais a serem observadas em sua adoção. Cf. Damian Laurey. "Reexamining U.S. tax sparing policy with developing countries: the merits of falling in line with international norms". Virginia Tax Review. v. 20, 2000, p. 469.
} 
Na visão defendida pela OCDE, o novo cenário global encorajaria, ou até mesmo ordenaria, a que se proceda ao reexame de estruturas e políticas fiscais já estabelecidas, dentre elas o tax sparing, que já vinha sendo adotado há mais de quatro décadas ${ }^{185}$.

De início, já se aponta que as mudanças ocorridas no cenário internacional levaram tanto os Estados membros da OCDE quanto os Estados não membros a repensar a inclusão de cláusulas de tax sparing nos acordos de bitributação, motivados, sobretudo, pelo reconhecimento de que estas cláusulas oferecem grandes oportunidades para a realização de planejamentos tributários e para a evasão fiscal ${ }^{186}$.

Além disso, a OCDE pontuou que até mesmo os Estados não membros da OCDE passaram a se preocupar com as concessões que se viam obrigados a fazer para que a outra parte na negociação (de um modo geral, um Estado membro da OCDE) concordasse com a inclusão da cláusula de tax sparing no acordo de bitributação negociado ${ }^{187}$.

Assim é que, para a obtenção do tax sparing, muitas vezes os Estados não membros da OCDE (países em desenvolvimento) acabam por ceder em pontos importantes, como a redução das alíquotas de tributação na fonte, ou regras mais rígidas para a caracterização de um estabelecimento permanente ${ }^{188}$. Por essa razão, tais Estados estariam questionando se o preço pago para a inclusão de uma cláusula de tax sparing não acabaria se revelando mais alto do que os benefícios dela advindos ${ }^{189}$.

Tendo em vista esta situação, no Relatório da OCDE são apresentadas, inicialmente, as críticas dessa Organização ao tax sparing, as quais são seguidas das sugestões (best practices) a serem adotadas relativamente a tais cláusulas, com a finalidade de minimizar as possibilidades de abuso ${ }^{190}$.

Nesse passo, a OCDE alega que, reconhecendo o direito dos Estados da fonte de estruturar seus sistemas tributários de acordo com seus próprios objetivos, o propósito do Relatório da OCDE seria o de promover uma reconsideração coletiva do tax sparing,

\footnotetext{
${ }^{185}$ Cf. OCDE, op. cit. (nota 1), p. 12.

${ }^{186}$ Cf. OCDE, op. cit. (nota 1), p. 3.

${ }^{187}$ Cf. OCDE, op. cit. (nota 1), p. 13.

${ }_{188}$ Cf. J. David B. Oliver, op. cit. (nota 140), p. 191.

${ }^{189}$ Cf. OCDE, op. cit. (nota 1), p. 13.

${ }^{190}$ Cf. OCDE, op. cit. (nota 1), p. 3.
} 
auxiliando no desenvolvimento de uma abordagem mais coerente sobre o assunto, por Estados membros e por Estados não membros da $\mathrm{OCDE}^{191}$.

Como se notará, os argumentos apresentados para fins da reconsideração proposta pela OCDE são, em sua maior parte, $\operatorname{vagos}^{192}$, baseando-se tão somente em alegações genéricas da Organização, as quais não se encontram devidamente evidenciadas em dados concretos e empíricos. Adiante-se, assim, que não nos parece que as razões apresentadas pela OCDE sejam suficientes para que se busque uma reconsideração da aplicação das cláusulas de tax sparing.

\subsubsection{Novo cenário econômico mundial}

Já na introdução do seu Relatório, a OCDE ocupa-se da demonstração de que, àquela época, os papéis desempenhados pelos países em desenvolvimento na economia global haviam se alterado com a globalização.

Assim, muitos países asiáticos e latino-americanos passaram a representar importante papel na economia global, respondendo por significativa parcela dos fluxos de comércio e investimentos mundiais, os quais, por essa razão, tornaram-se mais equilibrados, quando se consideram os Estados membros e Estados não membros da $\mathrm{OCDE}^{193}$.

Ademais, de acordo com o entendimento manifestado pela OCDE, a premissa de que todos os Estados membros são exportadores de capital e de que todos os Estados não membros são importadores de capital também vem sendo progressivamente questionada ${ }^{194}$.

Diante destes fatos e da assunção de que a concessão de cláusulas de tax sparing justificava-se pela necessidade de promover o desenvolvimento econômico em países em desenvolvimento, a OCDE argumenta que o cenário econômico mundial que se verifica na atualidade não mais justifica a utilização das cláusulas de tax sparing, não somente porque

\footnotetext{
${ }^{191}$ Cf. OCDE, op. cit. (nota 1), p. 10.

${ }^{192}$ Cf. Cristiane Coelho, op. cit. (nota 73), p. 694.

${ }^{193}$ Cf. OCDE, op. cit. (nota 1), p. 9.

${ }^{194}$ Cf. OCDE, op. cit. (nota 1), p. 10.
} 
o mercado global cresceu consideravelmente, mas também porque diversos países beneficiados por tais cláusulas são hoje economicamente desenvolvidos, inclusive até mais do que muitos países membros da $\mathrm{OCDE}^{195}$.

Em resumo, o ponto de vista expresso pela OCDE é o de que diversos Estados não membros da OCDE estão se igualando aos Estados membros (ou mesmo ultrapassando-os) em termos de nível de desenvolvimento econômico ${ }^{196}$, não sendo mais necessário (como era nas décadas de 1960 e 1970) adotar mecanismos de tax sparing como forma de auxílio ao desenvolvimento econômico daqueles países.

Ao elaborar tal raciocínio, a OCDE acaba por revelar que o tax sparing passou a ser uma preocupação para a Organização e para seus Estados membros na medida em que o fluxo de investimentos para os países em desenvolvimento se intensificou, fazendo com que os efeitos da cláusula em comento fossem efetivamente sentidos pelos ditos países desenvolvidos.

De fato, o texto do Relatório da OCDE parece sugerir que o problema, aqui, não é exatamente (ou apenas) o atual estágio econômico em que se encontram os países em desenvolvimento, mas sim a expressividade do montante das receitas tributárias que deixaram de ser recolhidas em função da adoção de cláusulas de tax sparing ${ }^{197}$.

Em outros termos, enquanto o tax sparing revelava-se inofensivo aos países desenvolvidos, em virtude dos inexpressivos fluxos de rendimentos beneficiados por esta cláusula, não eram apontados obstáculos à sua inclusão nos acordos de bitributação celebrados com países em desenvolvimento.

Não obstante, reconhece-se que muitos dos países com os quais países membros da OCDE negociaram acordos de bitributação com cláusulas de tax sparing apresentam hoje uma economia substancialmente mais desenvolvida, e que as disparidades entre os fluxos

\footnotetext{
${ }^{195}$ Cf. OCDE, op. cit. (nota 1), p. 21.

${ }^{196}$ Cf. OCDE, op. cit. (nota 1), p. 10; Cristiane Coelho, op. cit. (nota 73), p. 690.

${ }^{197}$ Com efeito, é esse entendimento que emerge da leitura do seguinte excerto: "The tax sparing device was developed at a time when the size of global trade and investment was relatively modest, national markets were heavily regulated and where there were extensive controls on inward and outward investment. As globalisation has radically increased the amount of cross-border trade and investment and lowered or eliminated traditional barriers on such activities, the potentially adverse effects on the residence country economy of granting tax sparing have become more evident in recent years." Cf. OCDE, op. cit. (nota 1), p. 21.
} 
de investimentos entre os países desenvolvidos e os países em desenvolvimento diminuíram.

De qualquer forma, ainda que se considere que as economias dos chamados países em desenvolvimento cresceram substancialmente, é certo que países como Índia e Brasil ainda não atingiram indicadores sociais aceitáveis, que os colocariam na situação de países desenvolvidos e que não dependem de investimentos estrangeiros, garantidos por cláusulas de tax sparing, como forma de fomentar seu desenvolvimento ${ }^{198}$.

\subsubsection{Tax sparing como instrumento de auxílio aos países em desenvolvimento}

Considerações relativas ao auxílio aos países em desenvolvimento são sempre levadas em consideração na negociação e concessão de cláusulas de tax sparing.

Contudo, consoante a visão manifestada pela OCDE em seu Relatório, vários dos mecanismos de controle relacionados a tais auxílios não estão presentes no tax sparing, uma vez que o Estado da residência normalmente não está envolvido nos aspectos concernentes aos incentivos fiscais concedidos pelo Estado da fonte ${ }^{199}$.

Pontua-se, ainda, o fato de que não haveria limites ao benefício conferido em virtude da cláusula de tax sparing, que não o próprio montante dos rendimentos auferidos pelos investidores estrangeiros no Estado da fonte. Desta forma, não é possível determinar, de antemão, quais são os custos para o Estado da residência decorrentes da concessão do tax sparing ${ }^{200}$.

Além disso, a OCDE ressalta que os negociadores dos acordos de bitributação normalmente não levam em consideração a natureza e extensão de eventuais outros auxílios diretos concedidos aos países em desenvolvimento ${ }^{201}$.

\footnotetext{
${ }^{198}$ Cf. Cristiane Coelho, op. cit. (nota 73), pp. 692-693; Luís Eduardo Schoueri, op. cit. (nota 40), p. 101.

${ }^{199}$ Cf. OCDE, op. cit. (nota 1), p. 22.

${ }^{200}$ Cf. OCDE, op. cit. (nota 1), p. 22.

${ }^{201}$ Cf. OCDE, op. cit. (nota 1), p. 22.
} 
Como aspecto positivo, menciona-se que o tax sparing é uma transferência automática de recursos, que promove diretamente o desenvolvimento do setor privado ${ }^{202}$.

\subsubsection{3. $\quad$ Tax sparing pode encorajar uma excessiva repatriação dos lucros}

Outra crítica ao tax sparing reside no fato de que ele não constituiria um real estímulo ao investimento nos países em desenvolvimento, uma vez que apenas atrairia investimentos de curto prazo $^{203}$.

Tal como mencionado, o propósito tipicamente atribuído ao tax sparing é o de atrair investimentos estrangeiros aos países em desenvolvimento. No entanto, nos termos do que a OCDE relata, o tax sparing pode acabar conduzindo a um efeito diferente do desejado, uma vez que os investidores estrangeiros sentir-se-iam estimulados a repatriar grande parte dos rendimentos auferidos no Estado da fonte, em vez de reinvesti-los, de modo a consolidar ou expandir o investimento original ${ }^{204}$. Em outros termos, o tax sparing acabaria por, potencialmente, reduzir os investimentos nos países em desenvolvimento ${ }^{205}$.

Com efeito, na corriqueira hipótese de constituição de subsidiárias no exterior, de modo geral a tributação dos rendimentos auferidos será diferida para o momento em que ocorrer a efetiva distribuição dos lucros. Diante da previsão de uma cláusula de tax sparing, ter-se-ia claro incentivo à distribuição dos lucros para a controladora em seu Estado da residência, no lugar da à utilização de tais lucros para reinvestimento e, consequentemente, promoção do desejado desenvolvimento econômico no Estado da fonte ${ }^{206}$.

Portanto, haveria um desestímulo ao reinvestimento no Estado da fonte, que seria incompatível com os objetivos pretendidos pelos países em desenvolvimento quando da negociação de acordos de bitributação com cláusulas de tax sparing ${ }^{207}$.

\footnotetext{
202 Cf. OCDE, op. cit. (nota 1), p. 22.

${ }^{203}$ Cf. OCDE, op. cit. (nota 1), pp. 22-23.

${ }^{204}$ Cf. OCDE, op. cit. (nota 1), pp. 22-23.

${ }^{205}$ Cf. Allison D. Christians, op. cit. (nota 43), pp. 693-694; Kim Brooks, op. cit. (nota 48), pp. 555-556.

${ }^{206}$ Cf. OCDE, op. cit. (nota 1), p. 23.

${ }^{207}$ Cf. OCDE, op. cit. (nota 1), pp. 22-23.
} 
Destarte, a OCDE recomenda aos países em desenvolvimento que analisem essa questão com o devido cuidado, para que se atinja o equilíbrio entre a necessidade de atração de investimentos estrangeiros e a necessidade de incentivar o reinvestimento dos lucros auferidos pelos investidores estrangeiros. O tax sparing seria, nesse contexto, um elemento que colocaria em risco o mencionado equilíbrio ${ }^{208}$.

\subsubsection{A premissa básica do tax sparing não é válida}

A OCDE também defende que a premissa básica sobre a qual se funda o tax sparing não é verdadeira. Destarte, argumenta-se que é falsa a ideia de que, na ausência do tax sparing, o Estado da residência seria o único a se beneficiar dos incentivos fiscais concedidos, pelo Estado da fonte, ao investidor estrangeiro ${ }^{209}$. Isso porque as empresas tenderiam a maximizar os incentivos fiscais recebidos, mesmo na ausência do tax sparing, de modo que a tributação pelo Estado da residência poderia nunca ocorrer, ou vir a ocorrer somente muito tempo depois ${ }^{210}$.

Como os benefícios do tax sparing somente podem ser usufruídos com a distribuição dos lucros e estes, em princípio, podem ter sua tributação no Estado da residência diferida de forma ilimitada, alega-se que o tax sparing seria desnecessário. Trata-se do argumento do diferimento, já referido no presente trabalho.

Com efeito, nos casos em que ocorre a constituição de subsidiárias no exterior, o diferimento da tributação permitido por várias legislações (entre elas, a norte-americana) para o momento em que os lucros sejam efetivamente distribuídos na forma de dividendos faria com que as empresas tendessem a represar os lucros no exterior. Menciona-se ainda que grande parte dos lucros sequer é distribuída na forma de dividendos, sendo reinvestida nos país em que estes foram gerados ou mesmo em outro país ${ }^{211}$.

É interessante notar como a OCDE, por um lado, alega que o tax sparing pode incentivar uma repatriação excessiva de lucros que seria nociva aos países em

\footnotetext{
${ }^{208}$ Cf. OCDE, op. cit. (nota 1), pp. 22-23.

${ }^{209}$ Cf. OCDE, op. cit. (nota 1), p. 23.

${ }^{210}$ Cf. OCDE, op. cit. (nota 1), pp. 23-24. No mesmo sentido, Alexander J. Easson, op. cit. (nota 48), p. 374.

${ }^{211}$ Cf. OCDE, op. cit. (nota 1), p. 24.
} 
desenvolvimento, mas por outro lado afirma que o tax sparing é irrelevante para fins de atração de investimentos estrangeiros por esses países, em razão de a tributação no Estado da residência ser diferida para o momento em que se der a efetiva distribuição dos lucros auferidos no exterior. Trata-se, claramente, de argumentação contraditória, mediante a utilização de dois argumentos essencialmente opostos, com o fim de se atingir o objetivo de infirmar a adoção das cláusulas de tax sparing.

Por fim, alega-se que devem ser levadas em conta as características específicas dos sistemas de crédito do imposto ao se analisar essa questão, pelo que se poderia concluir que, na hipótese em que (i) o Estado da fonte concede incentivos fiscais com vistas a atrair investimentos estrangeiros, (ii) não há previsão de cláusula de tax sparing e (iii) os rendimentos auferidos no Estado da fonte são distribuídos para a controladora, no Estado da residência (ou adicionados à base de cálculo da matriz, no caso de filiais no exterior), não seria verdadeiro que os mencionados incentivos fiscais acabem por ser revertidos, automaticamente, ao Estado da residência do investidor, como frequentemente se assume $^{212}$.

A justificativa de tal assertiva decorre do fato de que, em quase todos os países que adotam o método do crédito, permite-se que os créditos relativos a impostos pagos no exterior sejam considerados de maneira global, fazendo-se uma média entre os montantes pagos na fonte nos diversos países em que existam subsidiárias.

De tal modo, a distribuição dos lucros auferidos em países em que tenha havido baixa (ou nenhuma) tributação em virtude de benefícios fiscais concedidos para o investidor estrangeiro não necessariamente teria como efeito a transferência do mencionado benefício para o Estado da residência. Simplesmente, permitir-se-ia que o investidor pudesse se aproveitar de créditos de imposto excessivos, relativos a rendimentos auferidos em países em que a tributação seja mais gravosa.

Assim, conclui-se não ser verdadeira a afirmação de que, na ausência de cláusulas de tax sparing, os incentivos fiscais concedidos no Estado da fonte para atrair investidores estrangeiros acabam sendo transferidos ao Estado da residência destes investidores.

${ }^{212}$ Cf. OCDE, op. cit. (nota 1), p. 24. 
Nesse ponto, novamente, a OCDE adota argumento falacioso no intuito de infirmar a adoção do tax sparing. Isso porque a situação descrita é excepcional, haja vista que, ainda que se admita que tal permissão de fato exista na maioria dos países que utilizam o método do crédito para eliminar a dupla tributação ${ }^{213}$, o exemplo somente pode ser aplicado com relação a empresas controladoras que possuam subsidiárias em mais de uma jurisdição, sendo que em uma delas a tributação na fonte deverá ser significativamente maior do que a tributação no próprio Estado da residência, para tornar possível a compensação de eventuais créditos excessivos.

O exemplo apresentado pela OCDE no que diz respeito a este ponto é bastante ilustrativo do caráter excepcional dessa regra. Nele, é abordada a questão das mixer companies e seu tratamento no Reino Unido: uma vez que, naquela jurisdição, somente é permitida a compensação de impostos pagos no exterior com os tributos incidentes no Reino Unido sobre o mesmo rendimento, muitas empresas acabam por utilizar-se de mixer companies, que são suas subsidiárias diretas no exterior, por meio da qual a empresa britânica detém investimentos em outros países (holding company), alguns com níveis de tributação mais elevados e outros que não tributam a renda, ou a tributam em níveis reduzidos.

Conforme mencionado no próprio Relatório da OCDE, medidas destinadas a conter o uso abusivo de mixer companies foram até mesmo objeto de regulamentação pelo Parlamento britânico, o que somente ressalta que, diferentemente do que pretende alegar a OCDE, não é absolutamente natural a afirmação de que, na maioria das situações, a concessão de incentivos fiscais pelo Estado da fonte, sem a respectiva cláusula de tax sparing, não resultará em benefício para o Estado da residência do investidor estrangeiro.

\footnotetext{
${ }^{213}$ No Brasil, por exemplo, como regra geral, esta consideração global dos rendimentos e impostos pagos no exterior não é permitida, nos termos do artigo $14, \S 4^{\circ}$ da Instrução Normativa SRF $n^{\circ} 213 / 02$, a seguir transcrito:

“Art. 14. O imposto de renda pago no país de domicílio da filial, sucursal, controlada ou coligada e o pago relativamente a rendimentos e ganhos de capital, poderão ser compensados com o que for devido no Brasil. (...)

$\S 4^{\circ}$ A compensação do imposto será efetuada, de forma individualizada, por controlada, coligada, filial ou sucursal, vedada a consolidação dos valores de impostos correspondentes a diversas controladas, coligadas, filiais ou sucursais."
} 


\subsubsection{Efetividade dos incentivos fiscais}

Relata-se, ainda, que a utilização dos incentivos fiscais vem sendo questionada pelos Estados membros da OCDE, sendo por estes entendidos como uma forma inapropriada de promover o desenvolvimento econômico nos países em desenvolvimento $^{214}$.

Desta forma, ainda que muitos Estados membros prossigam reconhecendo políticas de incentivos fiscais, a tendência é que estas sejam cada vez mais específicas e direcionadas, voltadas a áreas específicas, em detrimento de políticas de incentivos de caráter geral ${ }^{215}$.

Diversos são os argumentos apresentados pela OCDE contra os incentivos fiscais, os quais estariam baseados em experiências e verificações empíricas de seus Estados membros. Assim é que se alega que, em muitas situações, a renúncia fiscal suportada acaba por superar o desejado acréscimo nos investimentos em virtude da concessão do incentivo. Isso aconteceria, sobretudo, porque o incentivo fiscal acaba por alcançar investimentos que ocorreriam de qualquer forma, mesmo na ausência de qualquer previsão de tributação mais benéfica para o investidor estrangeiro ${ }^{216}$.

Outra questão abordada pela OCDE com relação aos incentivos fiscais consiste nas pressões dos setores que por estes não forem privilegiados, sob a alegação de que se encontrariam em desvantagem competitiva quando comparados com os contribuintes beneficiados $^{217}$.

Tal linha de argumentação também poderia ser desenvolvida pelas empresas residentes dos países em desenvolvimento, as quais, diante de benefícios direcionados apenas a empresas estrangeiras, poderiam questionar o fato de se encontrarem em situação menos favorável ${ }^{218}$. Tal argumento desconsidera, por certo, a existência de incentivos fiscais pelos quais o Estado da fonte visa justamente estender ao investidor não residente um tratamento tributário que já é concedido aos seus investidores residentes.

\footnotetext{
${ }^{214}$ Cf. OCDE, op. cit. (nota 1), p. 25.

${ }^{215}$ Cf. OCDE, op. cit. (nota 1), pp. 25-26.

${ }^{216}$ Cf. OCDE, op. cit. (nota 1), p. 26.

${ }^{217}$ Cf. OCDE, op. cit. (nota 1), p. 28.

${ }^{218}$ Cf. OCDE, op. cit. (nota 1), p. 28.
} 
Além de pleitos dessa natureza, a OCDE menciona que, conforme demonstra a experiência, uma vez concedidos incentivos fiscais, a sua remoção é politicamente difícil, ainda que as razões que justificaram a concessão não mais existam ${ }^{219}$.

Assim, conclui-se que, ainda que a perda de receita decorrente da concessão de um incentivo fiscal direcionado possa não ser significativa, os custos totais de uma série de incentivos fiscais considerados em conjunto poderão representar uma grande perda de receitas tributárias para o país que os concede ${ }^{220}$.

\subsubsection{Cláusulas de tax sparing dão margem a práticas abusivas}

Uma das objeções mais contundentes da OCDE ao tax sparing reside nas possibilidades de planejamentos tributários abusivos e de evasão fiscal que ele proporcionaria, erodindo as receitas tributárias tanto do Estado da fonte quanto do Estado da residência ${ }^{221}$. No Relatório da OCDE, os tipos mais comuns de abuso envolvendo cláusulas de tax sparing foram separados em quatro grupos diferentes.

O primeiro deles consistiria na manipulação abusiva e artificial de lucros nas relações entre empresas ligadas, com a transferência destes para o Estado da fonte com o fim de obtenção dos benefícios do tax sparing (tributação menor no Estado da fonte e crédito fictício no Estado da residência), o que conduziria a uma perda de receitas tributárias pelo Estado da residência e demandaria grandes esforços para identificação e investigação ${ }^{222}$.

Com relação a este ponto, a própria OCDE adianta-se ao responder que, justamente para lidar com situações deste tipo, existem as regras de preços de transferência. Alega-se, no entanto, que a efetividade da aplicação das regras de preços de transferência depende,

\footnotetext{
${ }^{219}$ Cf. OCDE, op. cit. (nota 1), p. 28.

${ }^{220}$ Cf. OCDE, op. cit. (nota 1), p. 28.

${ }^{221}$ Cf. OCDE, op. cit. (nota 1), p. 12; Kim Brooks, op. cit. (nota 48), p. 555; Morvan Meirelles, op. cit. (nota 84), p. 263.

${ }^{222}$ Cf. OCDE, op. cit. (nota 1), p. 29.
} 
em grande parte, da eficiência da Administração, e que não necessariamente as referidas regras poderiam agir de forma a conter todos os casos de abuso ${ }^{223}$.

Outra forma típica de abuso mediante a utilização de cláusulas de tax sparing diz respeito à utilização de conduit companies. No caso clássico de utilização de conduit company, um investidor de um terceiro país busca beneficiar-se da cláusula de tax sparing de um acordo de bitributação existente entre o Estado A (fonte) e o Estado B (residência). Para tanto, constitui uma empresa no Estado B, por meio da qual investirá no Estado A. A empresa constituída no Estado B, mero canal para o investimento no Estado A, torna-se assim elegível aos benefícios da cláusula de tax sparing do acordo de bitributação entre o Estado A e o Estado B ${ }^{224}$.

O terceiro grupo de práticas abusivas consiste no que se chama de routing, i.e., a escolha, por instituições financeiras, de filiais ou subsidiárias em determinados países em desenvolvimento para a realização de suas operações, inclusive as operações financeiras, como os empréstimos, visando à utilização do mecanismo do tax sparing ${ }^{225}$.

Por fim, é indicado um exemplo de abuso pelo próprio governo do Estado da fonte relativamente ao tax sparing, com a elevação artificial das alíquotas de seu direito interno para que, na concessão do "incentivo fiscal" (i.e., aplicação da alíquota normal), o Estado da residência se visse obrigado a conceder um crédito equivalente à alíquota artificialmente elevada $^{226}$.

Ainda que seja possível compreender as motivações da OCDE ao criticar a utilização das cláusulas de tax sparing, não se pode negar que alguns argumentos apresentados são falaciosos e devem ser vistos com a devida cautela.

Inicialmente, destaque-se que a argumentação de que o tax sparing dá margem a planejamentos tributários abusivos parece contraditória com a afirmação, também da OCDE, de que os investidores estrangeiros, ao decidir acerca de seus investimentos, raramente são influenciados pela presença ou ausência de cláusulas de tax sparing ${ }^{227}$.

\footnotetext{
${ }^{223}$ Cf. OCDE, op. cit. (nota 1), p. 29.

${ }^{224}$ Cf. OCDE, op. cit. (nota 1), p. 29.

${ }^{225}$ Cf. OCDE, op. cit. (nota 1), p. 29.

${ }^{226}$ Cf. OCDE, op. cit. (nota 1), pp. 29-30.

${ }^{227}$ Cf. OCDE, op. cit. (nota 1), p. 12.
} 
Com efeito, por um lado a OCDE demonstra, de forma veemente, sua preocupação com a utilização abusiva das cláusulas de tax sparing, e de outra parte, afirma que as referidas cláusulas raramente influenciam as decisões dos investidores. Ora, se de fato há o abuso condenado pela OCDE, é certo que as cláusulas de tax sparing mostram-se vantajosas o suficiente para serem levadas em consideração pelos investidores estrangeiros na escolha dos países em que serão alocados seus investimentos.

Mencione-se que a OCDE não apresenta qualquer evidência concreta de que as cláusulas de tax sparing estão associadas ao aumento de práticas abusivas - as quais, digase, existem independentemente da presença do tax sparing ${ }^{228}$.

Assim, a possibilidade de abuso não pode, por si só, fazer com que o uso de tais cláusulas se torne desaconselhável, ainda mais se este revelar-se interessante para as partes $^{229}$. Os mecanismos para evitar abusos no âmbito dos acordos de bitributação são cada vez mais numerosos, de modo que os eventuais comportamentos abusivos por parte dos contribuintes ou dos Estados contratantes podem ser combatidos por outros meios que não o abandono das cláusulas de tax sparing (tais como cláusulas de limitações de benefícios ou de beneficiário efetivo).

\subsubsection{Dificuldades administrativas}

Por fim, são mencionadas as dificuldades administrativas enfrentadas pelos Estados membros da OCDE ao aplicarem as cláusulas de tax sparing. Nas hipóteses em que a cláusula de tax sparing faz referência a incentivos fiscais previstos em dispositivos específicos da legislação interna do Estado da fonte, seria difícil, ou mesmo impossível, ao Estado da residência, verificar se o contribuinte efetivamente foi beneficiado pelos referidos incentivos fiscais ${ }^{230}$.

No que diz respeito a esta objeção da OCDE, deve-se apontar que o mecanismo do matching credit foi criado justamente com a finalidade de resolver dificuldades

\footnotetext{
${ }^{228}$ Cf. Cristiane Coelho, op. cit. (nota 73), pp. 693-694.

${ }^{229}$ Cf. Luís Eduardo Schoueri, op. cit. (nota 40), p. 101.

${ }^{230}$ Cf. OCDE, op. cit. (nota 1), p. 29.
} 
encontradas na aplicação do tax sparing, tal como a determinação do montante do crédito a ser considerado pelo Estado da residência.

Com efeito, no capítulo do Relatório destinado a tratar das tendências que haviam sido adotadas por seus Estados membros em matéria de tax sparing na tentativa de lidar com os problemas decorrentes de sua aplicação, a OCDE menciona que uma das formas de evitar a incerteza quanto ao montante do crédito a ser concedido pelo Estado da residência, em razão da possibilidade de alterações na legislação interna do Estado da fonte, é a fixação do montante do crédito no próprio acordo de bitributação, seja no mesmo montante da alíquota máxima prevista no acordo para a tributação daquele determinado rendimento pelo Estado da fonte, ou em percentuais superiores ou inferiores ${ }^{231}$.

Trata-se, claramente, do matching credit, que não é assim denominado no Relatório da OCDE pelo fato de esta Organização normalmente fazer referência apenas ao tax sparing, ainda que se pretenda mencionar o mecanismo do matching credit.

Assim, a alegação de que o tax sparing é de difícil aplicação, porque vinculado à verificação da legislação interna do Estado da fonte, esbarra no reconhecimento de que existe o matching credit, no qual dificuldades dessa natureza não existem.

\subsubsection{Boas práticas na elaboração de cláusulas de tax sparing}

Em um dos capítulos do Relatório da OCDE, são apontadas algumas características que poderiam ser utilizadas pelos Estados membros que vierem a negociar cláusulas de tax sparing, de modo a se obter cláusulas mais específicas e direcionadas, o que reduziria as chances de abuso no Estado da fonte e no Estado da residência ${ }^{232}$.

A primeira delas consiste na definição precisa de quais são os incentivos fiscais abrangidos pela cláusula de tax sparing. Entende-se, assim, que menções genéricas aos incentivos destinados a promover o desenvolvimento econômico acabam por conferir ao

\footnotetext{
${ }^{231}$ Cf. OCDE, op. cit. (nota 1), p. 32.

${ }^{232}$ Cf. OCDE, op. cit. (nota 1), pp. 35-39.
} 
Estado da fonte uma discricionariedade muito grande na determinação da extensão do crédito a ser conferido pelo Estado da residência ${ }^{233}$.

Desta forma, a definição do incentivo fiscal sujeito ao tax sparing normalmente é feita por meio de uma referência direta à legislação do Estado da fonte, considerada, de forma estática, na data da assinatura do acordo de bitributação, para evitar que alterações subsequentes em tal legislação acabem por estender o escopo da cláusula de tax sparing. Em alguns acordos, são permitidas pequenas alterações nos incentivos fiscais, desde que suas principais características não sejam afetadas ${ }^{234}$.

Consoante relatado pela OCDE, as cláusulas de tax sparing normalmente não se aplicam aos rendimentos passivos, tais como juros e royalties, assim como são poucas as situações nas quais há previsão de matching credit. Na visão da Organização, tais características demonstrariam a preocupação dos Estados membros com práticas abusivas e com os incentivos fiscais destinados a investimentos passivos, desvinculados do desenvolvimento de atividades operacionais no Estado da fonte ${ }^{235}$.

Entende-se, assim, pela delimitação das cláusulas de tax sparing às atividades operacionais ou às atividades voltadas ao desenvolvimento econômico do Estado da fonte, tais como aquelas voltadas à infraestrutura, indústria etc., excluindo-se de seu escopo atividades de mera intermediação financeira ${ }^{236}$.

Em capítulo posterior, será possível notar que, na prática brasileira, as cláusulas de matching credit são mais comuns do que as cláusulas de tax sparing, e que estas normalmente aplicam-se a dividendos, juros e royalties. Caminha-se, portanto, em sentido oposto àquele que é entendido pela OCDE como o que reflete as melhores práticas em matéria de tax sparing.

Ao lado das boas práticas em matéria de tax sparing relacionadas aos incentivos fiscais e atividades abrangidas, há aquelas relacionadas às alíquotas aplicáveis, nas quais serão baseados os créditos concedidos pelo Estado da residência.

\footnotetext{
${ }^{233}$ Cf. OCDE, op. cit. (nota 1), p. 35.

${ }^{234}$ Cf. OCDE, op. cit. (nota 1), p. 35.

${ }^{235}$ Cf. OCDE, op. cit. (nota 1), p. 36.

${ }^{236}$ Cf. OCDE, op. cit. (nota 1), p. 36.
} 
Nesse passo, aponta-se que em alguns casos em que o crédito está baseado na alíquota aplicada internamente pelo Estado da fonte, limita-se a alíquota máxima a ser considerada para fins de tax sparing, de modo a evitar os já mencionados aumentos artificiais de alíquota pelo Estado da fonte, destinados apenas a incrementar o montante do crédito a ser concedido pelo Estado da residência ${ }^{237}$.

Outrossim, nas hipóteses em que tal alíquota máxima tenha sido definida, ou até mesmo quando o montante do crédito esteja definido no próprio acordo de bitributação (matching credit), comenta a OCDE que se tem entendido como inapropriado fixar alíquotas superiores àquelas previstas na legislação interna do Estado da fonte ${ }^{238}$.

No tocante a este ponto, menciona-se ainda que os créditos de tax sparing podem ser baseados nas alíquotas máximas previstas no acordo de bitributação para a tributação na fonte daquele determinado tipo de rendimento ${ }^{239}$.

Recomenda-se também que o tax sparing nunca seja concedido para rendimentos que, nos termos da legislação interna ou do acordo de bitributação, não sejam tributáveis no Estado da residência. Com efeito, esta recomendação é lógica, na medida em que o tax sparing é mecanismo que decorre do método do crédito e que é justificável em função deste $^{240}$.

Dado o entendimento de que as cláusulas de tax sparing estão sujeitas a abuso, alguns acordos de bitributação passaram a prever cláusulas antiabuso especificamente destinadas ao tax sparing. Alternativamente, menciona-se que nos casos em que o Estado da residência possua regra antiabuso prevista em sua legislação interna, poderão os Estados contratantes concordar expressamente em sujeitar a cláusula de tax sparing do acordo de bitributação aos ditames desta regra ${ }^{241}$.

O estabelecimento de limites temporais para a duração do tax sparing também é entendido como uma boa prática a ser adotada pelos Estados membros da OCDE que

\footnotetext{
${ }^{237}$ Cf. OCDE, op. cit. (nota 1), p. 36.

${ }^{238}$ Cf. OCDE, op. cit. (nota 1), p. 36.

${ }^{239}$ Cf. OCDE, op. cit. (nota 1), p. 37.

${ }^{240} \mathrm{Cf}$. OCDE, op. cit. (nota 1), p. 37.

${ }^{241}$ Cf. OCDE, op. cit. (nota 1), p. 37.
} 
vierem a negociar tal mecanismo, mediante o estabelecimento das já mencionadas sunset clauses $^{242}$.

Por fim, a OCDE recomenda a adoção de norma interpretativa nos acordos de bitributação que contenham cláusulas de tax sparing, para que se estabeleça que, em casos de conflito entre as normas destinadas ao combate das CFC (Controlled Foreign Corpanies) e as cláusulas de tax sparing, as primeiras deverão prevalecer - embora se reconheça que os investimentos visados pelas regras CFC geralmente estão fora do âmbito de aplicação das cláusulas de tax sparing ${ }^{243}$.

\subsubsection{Recomendações da OCDE relativas à adoção de cláusulas de tax sparing pelos Estados membros}

O último capítulo do Relatório da OCDE destina-se a recomendar aos Estados membros que avaliem a real necessidade de concordar com a inclusão de cláusulas de tax sparing nas negociações com países em desenvolvimento.

Ao longo do Relatório, a OCDE pontuou as principais questões relativas às cláusulas de tax sparing que, em seu entender, seriam preocupantes e conduziriam à sua não adoção. Tais objeções podem ser resumidas, essencialmente, nos seguintes pontos ${ }^{244}$ :

(i) Na possibilidades de abuso oferecidas pela utilização das cláusulas de tax sparing;

(ii) $\mathrm{Na}$ efetividade do tax sparing como instrumento de auxílio aos países em desenvolvimento; e

(iii) $\mathrm{Na}$ maneira como o tax sparing pode encorajar os países a utilizar os incentivos fiscais.

\footnotetext{
${ }^{242}$ Cf. OCDE, op. cit. (nota 1), pp. 37-38.

${ }^{243}$ Cf. OCDE, op. cit. (nota 1), pp. 38-39.

${ }^{244}$ Cf. OCDE, op. cit. (nota 1), p. 41.
} 
A Organização pontua que o seu objetivo ao publicar tal relatório não é o de fazer com que os Estados membros que tenham por política conceder cláusulas de tax sparing deixem de fazê-lo. Deve-se, contudo, verificar se o grau de desenvolvimento econômico do outro Estado contratante justifica a concessão de cláusulas deste tipo, bem como as possibilidades de abuso e o papel do tax sparing na competição entre os países em desenvolvimento ${ }^{245}$.

Da mesma forma, entende a OCDE que os Estados não membros que normalmente pleiteiam o tax sparing em suas negociações de acordos de bitributação também devem verificar se este é um instrumento efetivo na promoção de seu desenvolvimento econômico $^{246}$.

Em resumo, a recomendação da OCDE a seus Estados membros é que apenas concordem com a inclusão de cláusulas de tax sparing nas negociações com países que possuam um grau de desenvolvimento econômico consideravelmente inferior quando comparado ao dos Estados membros da OCDE, sendo que esta análise poderá ser feita mediante a aplicação de critérios econômicos objetivos ${ }^{247}$.

Uma vez que se concorde com a concessão do tax sparing, a modelagem da cláusula deverá se pautar pelas boas práticas na matéria, expostas no tópico precedente, as quais têm por finalidade minimizar as chances de abuso na aplicação do mecanismo ${ }^{248}$.

\subsection{As cláusulas de tax sparing e matching credit na Convenção Modelo da ONU}

Em 1967, o Conselho Econômico e Social da Organização das Nações Unidas criou o Ad Hoc Group of Experts on Tax Treaties Between Developed and Developing Countries (“Grupo"), que possuía dez representantes de países desenvolvidos e dez representantes de países em desenvolvimento ${ }^{249}$.

\footnotetext{
${ }^{245}$ Cf. OCDE, op. cit. (nota 1), p. 42.

${ }^{246}$ Cf. OCDE, op. cit. (nota 1), p. 42.

${ }^{247}$ Cf. OCDE, op. cit. (nota 1), pp. 42-43.

${ }^{248}$ Cf. OCDE, op. cit. (nota 1), pp. 42-43.

${ }^{249}$ Cf. Kim Brooks, op. cit. (nota 48), p. 526.
} 
O referido Grupo trabalhou, durante a década de 1970, no desenvolvimento de uma Convenção Modelo que pudesse ser mais favorável aos países em desenvolvimento do que a Convenção Modelo da OCDE, claramente modelada de acordo com os interesses dos países desenvolvidos ${ }^{250}$.

Em 1980, foi finalmente publicada a Convenção Modelo da ONU, a qual foi atualizada em 2001 e em 2008. Embora esta seja de fato mais favorável aos países em desenvolvimento do que a Convenção Modelo da OCDE, nota-se que aproximadamente $90 \%$ de seu conteúdo das duas Convenções Modelo é idêntico ${ }^{251}$.

Desta forma, no artigo 23 da Convenção Modelo, não se propõe a redação de uma cláusula de tax sparing, tendo-se optado pela reprodução dos preceitos da Convenção Modelo da OCDE. A ausência de uma previsão expressa de cláusula de tax sparing foi interpretada, à época, como um reconhecimento de que também na ONU havia uma tendência a se privilegiar os interesses dos países desenvolvidos, ou mesmo o insucesso de tais países ao apreciar as necessidades dos países em desenvolvimento ${ }^{252}$.

Tampouco os Comentários ao artigo 23 da Convenção Modelo da ONU expressaram maior entusiasmo em relação às cláusulas de tax sparing, na medida em que simplesmente reproduziram os Comentários ao artigo 23 da Convenção Modelo da OCDE de 1977, mantendo-se tal situação nas revisões de 2001 e 2008.

Ademais, nas considerações gerais que antecedem os Comentários ao artigo 23, resta evidente o conflito entre os países desenvolvidos e os países em desenvolvimento que fazem parte do Grupo ${ }^{253}$. Enquanto os primeiros alegam que o tax sparing não é a medida mais apropriada, haja vista que fatores tributários não seriam os mais relevantes nas decisões relativas à alocação de investimentos, os últimos entendem que a inclusão das cláusulas de tax sparing é um objetivo básico e fundamental a ser perseguido na negociação de acordos de bitributação ${ }^{254}$.

Apesar do conflito de opiniões que parece ter permeado os trabalhos do Grupo, nas referidas considerações gerais ao artigo 23 da Convenção Modelo da ONU, o tax sparing é

\footnotetext{
${ }^{250}$ Cf. Kim Brooks, op. cit. (nota 48), p. 526.

${ }^{251}$ Cf. Claudio Sacchetto, op. cit. (nota 66), p. 77

${ }^{252}$ Cf. Kim Brooks, op. cit. (nota 48), p. 527.

${ }^{253}$ Cf. Patrick L. Kelley. "Tax treaties between United States and developing countries: the need for a new U.S. initiative". The American Journal of International Law. v. 65, n. 1, janeiro, 1971, pp. 161-162.

${ }^{254} \mathrm{Cf}$. Comentários ao artigo 23 da Convenção Modelo da OCDE, parágrafo $4^{\circ}$.
} 
apontado como o meio mais efetivo de preservar os efeitos dos incentivos fiscais concedidos pelos países importadores de capital ${ }^{255}$.

Portanto, pode-se dizer que, em razão da existência de interesses conflitantes no Grupo que trabalhou no desenvolvimento da Convenção Modelo da ONU, houve de fato certa relutância da Organização em assumir uma postura verdadeiramente favorável ao tax sparing. Nada obstante, consoante já apontado, as cláusulas de tax sparing (e matching credit) passaram a ser amplamente utilizadas, tantos pelos países desenvolvidos quanto pelos países em desenvolvimento.

${ }^{255}$ Cf. Comentários ao artigo 23 da Convenção Modelo da OCDE, parágrafo $6^{\circ}$. 


\section{AS CLÁUSULAS DE TAX SPARING E MATCHING CREDIT NOS DEMAIS PÁISES}

\subsection{A posição norte-americana a respeito das cláusulas de tax sparing}

No presente capítulo, propõe-se inicialmente a discussão acerca da posição adotada pelos Estados Unidos a respeito das cláusulas de tax sparing, a qual se firmou no final da década de 1970 e persiste até o presente.

Conforme mencionado no capítulo anterior, recentemente a OCDE e, alegadamente, os países desenvolvidos que dela fazem parte, passaram a questionar a concessão de cláusulas de tax sparing, pelas várias razões já apontadas. No entanto, todos os países desenvolvidos, com exceção dos Estados Unidos, celebraram acordos de bitributação com países em desenvolvimento que continham cláusulas de tax sparing ou matching credit - ainda que hoje não mais concordem com o referido mecanismo.

Desta forma, dentre os países desenvolvidos, os Estados Unidos ganham destaque por não possuírem, em sua rede de acordos internacionais para evitar a bitributação, nenhum que contenha cláusulas de tax sparing ou matching credit. Trata-se, como se verá adiante, do principal motivo pelo qual Brasil e Estados Unidos não ratificaram um acordo de bitributação até os dias de hoje.

\subsubsection{Histórico da posição norte-americana a respeito das cláusulas de tax sparing}

A política norte-americana de não incluir cláusulas de tax sparing nos acordos de bitributação celebrados com países menos desenvolvidos teve início no final da década de $1950^{256}$.

${ }^{256}$ Cf. J. David B. Oliver, op. cit. (nota 140), p. 190. 
Relata-se que, no que diz respeito aos Estados Unidos, o tax sparing foi mencionado inicialmente por George M. Humphrey, que à época era Secretário do Tesouro daquele país, em uma conferência realizada em 1955 no Rio de Janeiro ${ }^{257}$.

Nesse mesmo ano de 1955, o então Presidente Dwight D. Eisenhower recomendou ao Congresso a adoção do tax sparing ${ }^{258}$, sendo esta a orientação que passou a ser seguida pelo Tesouro norte-americano, o qual tentou, sem sucesso, incluir cláusulas do gênero em diversos acordos celebrados no período ${ }^{259}$.

Nesse primeiro momento, a menção ao tax sparing devia-se ao reconhecimento de que os Estados Unidos falhavam na tarefa de induzir investimentos americanos no exterior, bem como de que o sistema tributário do país acabava por negar quaisquer incentivos oferecidos pelos países menos desenvolvidos, seja na América do Sul, África ou Ásia, às pessoas físicas e jurídicas americanas que desejassem iniciar novos empreendimentos nessas áreas ${ }^{260}$.

Nessa esteira, em 1957 foi submetido à apreciação do Senado um acordo de bitributação celebrado pelos Estados Unidos com o Paquistão, o qual continha cláusula de tax sparing. Tal cláusula era o meio encontrado pelo Tesouro norte-americano para eliminar o efeito negativo que o sistema tributário americano acabava por impor aos incentivos fiscais concedidos pelos países estrangeiros ao desenvolvimento de negócios por residentes dos Estados Unidos em seus territórios ${ }^{261}$.

Conforme relata Howard M. Liebman, o acordo de bitributação firmado por Estados Unidos e Paquistão, a despeito de ser um dos únicos acordos dos Estados Unidos com países em desenvolvimento, seguia, em termos gerais, as disposições constantes dos acordos firmados com países mais desenvolvidos. No entanto, a diferença fundamental residia na inclusão da cláusula de tax sparing, pela qual se concedia o crédito, nos Estados Unidos, relativamente ao imposto que teria sido pago por seus residentes no Paquistão,

\footnotetext{
${ }^{257}$ Cf. Matthew J. Kust. "Tax treaties with the underindustrialized countries”. The Tax Executive. v. 13, 1961, p. 176.

${ }^{258}$ Conforme mencionado por Deborah Toaze: "In 1955, President Einsenhower endorsed tax sparing in his foreign economic message to Congress when he stated: '[U]nder proper safeguard, credit could be given for foreign income taxes which are waived for an initial limited period, as we now grant a credit for foreign taxes which are imposed. This would give maximum effectiveness to foreign tax laws that are designed to encourage new enterprises." Cf. Deborah Toaze, op. cit. (nota 175), p. 883.

${ }^{259}$ Cf. Damian Laurey, op. cit. (nota 184), p. 475.

${ }^{260}$ Cf. Matthew J. Kust. "The Pakistan Tax Treaty". The Tax Executive. v. 10, 1958, p. 303.

${ }^{261}$ Cf. Matthew J. Kust, op. cit. (nota 260), p. 303.
} 
mas que não o foi por conta de seu programa de incentivo para o estímulo do desenvolvimento econômico ${ }^{262}$.

Cabe, aqui, tecer breves considerações sobre a cláusula de tax sparing constante do Artigo XV do acordo de bitributação entre Estados Unidos e Paquistão. Eis o que dispunha o trecho do referido dispositivo que tratava da concessão do tax sparing:

"ARTICLE XV

(Avoidance of Double Taxation)

(...) For the purposes of this credit there shall be deemed to have been paid by a United States domestic corporation the amount by which such Pakistan taxes (other than the business profits tax) have been reduced under the provisions of section 15B of the Income Tax Act, 1922 (XI of 1922) as in effect on the date of the signature of the present Convention: Provided, That any extension made by law of the period within which an industrial undertaking may be set up or commenced in order to obtain the reduction provided in section 15B shall be deemed to be in effect on the date of the signature of the present Convention."

Como se pode notar, o tax sparing do acordo entre Estados Unidos e Paquistão fazia referência a benefício fiscal previsto na Seção $15 \mathrm{~B}$ da lei paquistanesa do imposto de renda, a qual foi promulgada em $1948^{263}$.

Em termos gerais, a Seção 15B isentava os lucros auferidos por novos empreendimentos industriais que empregassem pelo menos 50 pessoas e utilizassem energia elétrica $^{264}$, por um período de cinco anos, estando a referida isenção limitada a $5 \%$ do capital aplicado por ano.

Tratava-se, assim, de uma isenção bastante limitada, no que diz respeito ao tempo, ao montante e aos empreendimentos abrangidos. Além disso, não havia a previsão de utilização posterior da parcela isenta que porventura não pudesse ter sido aproveitada (carry over $^{265}$. Assim, sendo apurado prejuízo ou baixa lucratividade nos anos iniciais, de modo que o limite anual da isenção não fosse aproveitado (total ou parcialmente), o benefício seria perdido, não podendo ser utilizado posteriormente pelo contribuinte.

262 Cf. Howard M. Liebman. "A formula for tax-sparing credits in U.S. tax treaties with developing countries”. The American Journal of International Law. v. 72, n. 2, abril, 1978, p. 296.

${ }^{263}$ Cf. Matthew J. Kust, op. cit. (nota 260), p. 304.

${ }^{264}$ Conforme aponta Matthew J. Kust, a isenção era limitada a novas empresas que se dedicassem às atividades de (i) manufatura de mercadorias, (ii) construção de navios e navegação, (iii) geração e transmissão de energia elétrica ou hidráulica, (iv) exploração de minas, poços de petróleo ou jazidas minerais, ou $(v)$ que estivessem envolvidas em qualquer empreendimento industrial para o qual a isenção fosse declarada como aplicável. Em 1956, a isenção foi ampliada, para incluir empreendimentos que se enquadrassem nas categorias $(\boldsymbol{i})$ ou $(v)$ constituídos após $1^{\circ}$ de abril de 1955 e que empregassem 10 ou mais pessoas e utilizassem energia, ou 20 pessoas sem o uso de energia elétrica. Cf. Matthew J. Kust, op. cit. (nota 260), p. 304.

${ }^{265}$ Cf. Matthew J. Kust, op. cit. (nota 260), pp. 304-305. 
Deve-se mencionar que, além do escopo limitado do benefício fiscal previsto na Seção 15B da lei do imposto de renda do Paquistão, mencionou-se à época sua ineficácia, em virtude de outros incentivos da legislação paquistanesa não reconhecidos para fins de aplicação da cláusula de tax sparing do acordo entre Estados Unidos e Paquistão ${ }^{266}$.

Destarte, regras de dedutibilidade de despesas de depreciação bastante favoráveis, aplicáveis em momento anterior ao da aplicação da Seção 15B, acabavam por fazer com que a legislação isentiva sequer chegasse a ser cogitada, pela total ausência de lucros tributáveis nos novos empreendimentos após a consideração da depreciação acelerada (que poderia chegar a 55\% no primeiro ano para novas plantas industriais e maquinário). As despesas de depreciação que não pudessem ser utilizadas em determinado período poderiam, além disso, ser aproveitadas em períodos posteriores, sem qualquer limitação temporal $^{267}$.

Junte-se a isso o fato de que os prováveis prejuízos operacionais verificados nos primeiros anos dos novos empreendimentos constituídos no Paquistão poderiam ser aproveitados por seis anos, nos termos da legislação do imposto de renda do país ${ }^{268}$. Temse, assim, que a Seção 15B mostrava-se, na realidade, de reduzida aplicação prática ${ }^{269}$.

As mencionadas características da legislação paquistanesa levaram Matthew J. Kust a questionar por quais razões teriam os Estados Unidos escolhido um incentivo fiscal tão ineficaz e desprovido de sentido para dar início ao tax sparing em seus acordos de bitributação, sugerindo como resposta a possibilidade de as autoridades fiscais americanas não terem compreendido a complexa legislação paquistanesa - para reconhecer, em seguida, ser difícil aceitar tal hipótese ${ }^{270}$.

Da mesma forma, pareceu-lhe também intrigante entender os motivos que teriam levado o Paquistão a fazer diversas concessões na negociação do acordo em troca de uma cláusula de tax sparing que se mostrava, ao final, de insignificante aplicação prática ${ }^{271}$.

O acordo de bitributação assinado entre Estados Unidos e Paquistão é considerado como aquele em que o Senado norte-americano mais próximo esteve de aprovar uma

\footnotetext{
${ }^{266}$ Cf. Matthew J. Kust, op. cit. (nota 257), pp. 180-181.

${ }^{267}$ Cf. Matthew J. Kust, op. cit. (nota 260), pp. 305-306.

${ }^{268}$ Cf. Matthew J. Kust, op. cit. (nota 260), p. 308.

${ }^{269}$ Cf. Matthew J. Kust, op. cit. (nota 260), pp. 305-306.

${ }^{270}$ Cf. Matthew J. Kust, op. cit. (nota 260), p. 309.

${ }^{271}$ Cf. Matthew J. Kust, op. cit. (nota 260), pp. 310-311.
} 
cláusula de tax sparing ${ }^{272}$. A propósito da discussão de seu texto, duas audiências ocorreram no Comitê de Relações Exteriores do Senado, em 30 de julho e em 09 de agosto de 1957.

Inicialmente, além dos responsáveis pela negociação do referido acordo, também muitos senadores mostraram-se favoráveis à inclusão da cláusula de tax sparing no acordo de bitributação celebrado com o Paquistão, entendendo ser esta uma concessão razoável por parte do governo americano ${ }^{273}$.

Contudo, na audiência de 09 de agosto de 1957, Stanley S. Surrey, professor da Faculdade de Direito de Harvard, pronunciou-se a respeito do tema, apresentando diversos argumentos contrários à aprovação do texto do acordo entre Estados Unidos e Paquistão tal como estava redigido, contendo a cláusula de tax sparing do Artigo $\mathrm{XV}^{274}$. Com seu discurso, Stanley S. Surrey acabou por conseguir incutir nos senadores dúvidas acerca da conveniência e viabilidade de se incluir o tax sparing no acordo assinado com o Paquistão $^{275}$.

Após longas discussões no Senado, o acordo com o Paquistão foi finalmente aprovado com uma reserva, que excluía a cláusula de tax sparing inicialmente prevista, sob o argumento de que o incentivo fiscal paquistanês que seria objeto do crédito fictício a ser concedido pelos Estados Unidos havia expirado.

Nesse mesmo período, outros três acordos contra a dupla tributação que também continham cláusulas de tax sparing, firmados com Índia ${ }^{276}$, Israel e Emirados Árabes Unidos, foram apresentados ao Senado norte-americano para ratificação ${ }^{277}$. Tais acordos

${ }^{272}$ Cf. Damian Laurey, op. cit. (nota 184), p. 475.

${ }^{273}$ Cf. Damian Laurey, op. cit. (nota 184), p. 476.

${ }^{274}$ Cf. UNITED STATES SENATE, op. cit. (nota 124), pp. 1-34.

275 Cf. Charles Gustafson. "The USA". LANG, Michael; PISTONE, Pasquale; SCHUCH, Josef; STARINGER, Claus (editores). The impact of the OECD and the UN Model Conventions on bilateral tax treaties. Cambridge: Cambridge University, 2012, pp. 1.172-1.173.

${ }^{276}$ Note-se que também houve críticas relativas à ineficácia da cláusula de tax sparing prevista no acordo de bitributação celebrado entre Estados Unidos e Índia, que dizia respeito ao incentivo previsto na Seção $15 \mathrm{C}$ da lei indiana, pelas mesmas razões apontadas ao se analisar o acordo com o Paquistão. Nesse sentido, veja-se trecho do Report of the Taxation Enquiry Commission (1953-1954), do Governo da Índia, citado por Matthew J. Kust: "The main reason for the ineffectiveness of Section 15C is the grant of initial and additional depreciation allowances which, together with normal depreciation allowances, make up nearly 80 to 85 per cent of the cost of fixed assets in the form of plant and machinery within the first five years of the life of the concern. As these depreciations allowances have to be deducted first before computing profits for purposes of income tax it has been difficult for any appreciable number of new concerns to claim the benefits conferred under Section 15C." Cf. Matthew J. Kust, op. cit. (nota 257), p. 183.

${ }^{277}$ Cf. Howard M. Liebman, op. cit. (nota 262), p. 296. 
não chegaram a receber a aprovação do Senado, e foram retirados do Comitê de Relações Exteriores em $1964^{278}$.

Desde então, os Estados Unidos vêm adotando como prática recusar a assinatura de qualquer acordo que contenha tal cláusula ${ }^{279}$, sendo que tal postura, até hoje, fundamentase nos argumentos de Stanley S. Surrey contrariamente à adoção da cláusula de tax sparing no acordo assinado por Estados Unidos e Paquistão.

Ressalte-se que tal política não chegou a ser formalmente declarada pelo Senado norte-americano, sendo possível inferi-la, desde o final da década de 1950, das sucessivas negativas de aprovação integral dos acordos que contivessem cláusulas de tax sparing ${ }^{280}$.

A recusa dos Estados Unidos em assinar instrumento no qual os incentivos fiscais sejam utilizados como uma forma de auxiliar no desenvolvimento de determinados países é tida como a principal razão para a ausência de acordos contra a dupla tributação entre os Estados Unidos e países em desenvolvimento, os quais, como já mencionado, buscam atrair os investimentos privados através da concessão de incentivos fiscais aos investidores estrangeiros e, por esse motivo, tendem a incluir cláusulas de tax sparing em seus $\operatorname{acordos}^{281}$.

Nesse sentido, Willard B. Taylor afirma que seria inesperado que os Estados Unidos viessem a concordar com a adoção de cláusulas de tax sparing ou com acordos nos quais estivesse prevista a isenção de tributação norte-americana sobre rendimentos auferidos no outro país ${ }^{282}$.

\footnotetext{
${ }^{278}$ Cf. Howard M. Liebman, op. cit. (nota 262), p. 296.

${ }^{279}$ Cf. Reuven S. Avi-Yonah. "Globalization and tax competition: implications for developing countries". TANZI, Vito; BARREIX, Alberto; VILLELA, Luiz (editors). Taxation and Latin American Integration. Washington: Inter-American Development Bank. Cambridge: David Rockefeller Center for Latin American Studies Harvard University, 2008, p. 182.

${ }^{280}$ Cf. Yong Suk Oh. "A critique of U.S. policy on the tax sparing credit, from the perspective of less developed countries". The Korean Journal of Comparative Law. v. 15, 1987, p. 51.

${ }^{281}$ Cf. Howard M. Liebman, op. cit. (nota 262), p. 296.

${ }^{282}$ Cf. Willard B. Taylor. "O que um acordo de bitributação entre Brasil e EUA poderia estipular?". Tradução de Flávio Rubinstein. COSTA, Alcides Jorge; SCHOUERI, Luís Eduardo; BONILHA, Paulo Celso Bergstrom (coords.). Direito Tributário Atual. v. 21. São Paulo: Dialética: IBDT, 2007, p. 153.
} 
Como resultado dessa política, é de se notar que os Estados Unidos possuem menos acordos com países em desenvolvimento do que os demais países desenvolvidos, de um modo geral ${ }^{283}$.

Reuven Avi-Yonah faz especial referência aos países da América Latina: os Estados Unidos possuem acordos para evitar a dupla tributação apenas com o México e com a Venezuela, tendo denunciado seus acordos com Honduras e Nicarágua e negociado, sem nunca ratificar, acordos com Brasil e Argentina ${ }^{284}$.

No entendimento dos países em desenvolvimento, a visão norte-americana a respeito das cláusulas de tax sparing acaba, a um só tempo, por invalidar sua legislação concessiva de incentivos fiscais e por desrespeitar seu direito soberano de tributar os rendimentos gerados dentro dos limites de seus territórios ${ }^{285}$.

\subsubsection{Objeções dos Estados Unidos à adoção de cláusulas de tax sparing}

Como mencionado, a cláusula de tax sparing prevista no acordo de bitributação entre Estados Unidos e Paquistão foi rejeitada pelo Senado norte-americano, em 1957, nos termos do pronunciamento de Stanley S. Surrey a este respeito, perante o Comitê de Relações Exteriores do Senado ${ }^{286}$.

De fato, a despeito da mencionada irrelevância da cláusula de tax sparing prevista no acordo entre Estados Unidos e Paquistão, uma vez que o benefício fiscal subjacente a esta era de mitigada utilidade prática, Stanley S. Surrey realizou caloroso discurso perante o Senado com a finalidade de impedir sua aprovação - bem como das eventuais futuras cláusulas de tax sparing que viessem a ser submetidas ao escrutínio desse órgão.

Desde então, nenhum acordo de bitributação contendo cláusula de tax sparing foi ratificado, e os argumentos de Stanley S. Surrey vêm sendo consistentemente adotados

\footnotetext{
283 "As a result, the United States has a smaller treaty network with developing countries than its trade rivals.” Cf. Damian Laurey, op. cit. (nota 184), p. 471.

${ }^{284}$ Cf. Reuven S. Avi-Yonah, op. cit. (nota 279), p. 182. No mesmo sentido, cf. Allison D. Christians, op. cit. (nota 43), p. 695.

${ }^{285}$ Cf. Damian Laurey, op. cit. (nota 184), p. 471.

${ }^{286}$ Cf. UNITED STATES SENATE, op. cit. (nota 124), pp. 1-34.
} 
pelos Estados Unidos, como forma de justificar sua política de não inclusão de cláusulas de tax sparing em seus acordos de bitributação.

Um dos principais argumentos aventados por Stanley S. Surrey é o de que o tax sparing acabava servir de instrumento de discriminação dos investimentos domésticos, que assim passariam a estar sujeitos a tributação superior àquela aplicável aos investimentos realizados por norte-americanos no exterior (no caso, no Paquistão) ${ }^{287}$.

De fato, o argumento da neutralidade de exportação de capitais (CEN) é frequentemente adotado pelos opositores do tax sparing, que têm nos Estados Unidos seu maior representante ${ }^{288}$. Alega-se que os sistemas tributários devem ser neutros, de tal modo que considerações de natureza fiscal não devem ser consideradas pelos investidores ao decidirem por investir em seu país ou no exterior, de modo que seja possível atingir uma alocação eficiente de recursos ${ }^{289}$.

No entanto, é interessante notar que tal argumento não é plenamente válido, haja vista que os próprios Estados Unidos, como outros países desenvolvidos, acabam por se desviar da neutralidade de exportação de capitais por meio da aplicação do método do crédito $^{290}$.

Com efeito, fosse o sistema americano neutro sob o aspecto da exportação de capitais, o residente americano teria a possibilidade de se creditar, ou mesmo obter um reembolso, dos impostos pagos sobre rendimentos auferidos no exterior que excedam ao imposto cobrado nos Estados Unidos sobre a mesma parcela de rendimentos. Nesta hipótese, claramente o investimento no exterior torna-se menos atrativo que o investimento nos Estados Unidos, em claro descompasso com a neutralidade de exportação de capitais $^{291}$.

No mesmo sentido, Luís Eduardo Schoueri questiona a neutralidade da exportação de capitais nas relações entre países desenvolvidos e países em desenvolvimento, já que,

${ }^{287}$ Cf. UNITED STATES SENATE, op. cit. (nota 124), pp. 1-4; Allison D. Christians, op. cit. (nota 43), p. 694; Harry A. Shannon III, op. cit. (nota 44), p. 88; Yariv Brauner, op. cit. (nota 84), p. 122.

${ }^{288}$ Cf. Kim Brooks, op. cit. (nota 48), p. 554.

${ }^{289}$ Cf. OCDE, op. cit. (nota 1), p. 19; Richard Mitchell. "United States-Brazil bilateral income tax treaty negotiations". Hastings International \& Comparative Law Review. v. 21, 1997, p. 230; Lawrence D. Hollman. "Tax legislation affecting foreign operations - II: further proposals". The Tax Executive. v. 10, 1958, p. 287; Luís Eduardo Schoueri, op. cit. (nota 40), p. 103.

${ }^{290}$ Cf. Damian Laurey, op. cit. (nota 184), p. 486; Luís Eduardo Schoueri, op. cit. (nota 40), p. 104.

${ }^{291}$ Cf. Damian Laurey, op. cit. (nota 184), p. 469; Luís Eduardo Schoueri, op. cit. (nota 40), p. 104. 
considerando-se exatamente o mesmo nível de tributos nos dois países (país desenvolvido e país em desenvolvimento), certamente o investidor preferirá investir naquele que lhe oferecer melhor infraestrutura, i.e., no país desenvolvido. Assim, "quando um país desenvolvido adota a neutralidade de exportação, ele convida seu contribuinte a investir localmente (ou em outro país desenvolvido)"292.

Damian Laurey aponta ainda que o sistema norte-americano não é neutro na perspectiva da exportação de capitais por desencorajar a distribuição dos lucros auferidos no exterior, pela sistemática do diferimento ${ }^{293}$.

Ora, a possibilidade de diferimento da tributação ${ }^{294}$, nos casos em que a atuação das empresas americanas no exterior ocorra sob a forma de constituição de subsidiárias, é argumento normalmente aventado pelos detratores do tax sparing como uma forma de comprovar que o mecanismo não seria necessário, considerando-se que o valor presente da futura obrigação tributária, que poderá nem sequer se materializar, poderia ser próximo a zero $^{295}$.

Nota-se, assim, a falácia dos argumentos utilizados pelos Estados Unidos para infirmar a utilização do tax sparing: alega-se, num primeiro momento, que as cláusulas de tax sparing não são desejáveis na medida em que não atendem à neutralidade de exportação de capitais; por outro lado, alega-se que não são necessárias, porque o diferimento da tributação norte-americana para o momento da distribuição dos lucros auferidos no exterior evita que o incentivo fiscal concedido no país em desenvolvimento seja transferido ao Tesouro dos Estados Unidos. Ocorre, contudo, que o diferimento estatuído pela legislação norte-americana também não atende aos ditames da neutralidade de exportação de capitais.

Além disso, o tax sparing também foi entendido por Stanley S. Surrey, novamente, como desnecessário, na medida em que parte do crédito atribuído segundo essa sistemática

\footnotetext{
${ }^{292}$ Cf. Luís Eduardo Schoueri, op. cit. (nota 40), p. 104.

${ }^{293}$ Cf. Damian Laurey, op. cit. (nota 184), p. 486.

${ }^{294}$ Com efeito, por meio do tax deferral, previsto no Internal Revenue Code, não incidirá o imposto de renda norte-americano sobre os rendimentos auferidos no exterior por empresas estrangeiras, ainda que controladas por contribuintes dos Estados Unidos, até que tais valores sejam efetivamente repatriados, o que geralmente ocorre sob a forma de dividendos. Cf. Howard M. Liebman, op. cit. (nota 262), p. 298.

${ }^{295}$ Cf. Kim Brooks, op. cit. (nota 48), p. 512; Lawrence D. Hollman, op. cit. (nota 289), p. 288; H. David Rosenbloom. "Trends in tax treaties between the United States and developing countries". UN Draft Model Taxation Convention. Deventer: Kluwer, 1979, pp. 19-20; Reuven S. Avi-Yonah, op. cit. (nota 279), pp. 182-
} 183. 
não corresponde a uma situação de bitributação, que o método do crédito tradicional busca evitar $^{296}$.

A validade de tal afirmação é contestada por Damien Laurey, que afirma que, caso fossem concedidos subsídios diretos às empresas norte-americanas pelos países em desenvolvimento, tal benefício não poderia ser anulado em razão da aplicação do método do crédito. Assim, a concessão de um incentivo fiscal equivale à concessão de um subsídio direto, devendo por essa razão ser tratada como tal ${ }^{297}$, sem que possa ser anulado por um excesso de tributação no Estado da residência.

Outra alegação de Stanley S. Surrey era a de que aceitar o tax sparing no acordo com o Paquistão faria com que os demais países em desenvolvimento passassem a tentar obter concessões similares dos Estados Unidos, gerando intenso e inédito lobby ao processo de negociação dos acordos de bitributação ${ }^{298}$.

A respeito deste ponto, cumpre destacar que em diversos acordos celebrados pelos Estados Unidos existe, atualmente, a previsão de que caso o tax sparing venha a ser concedido em outro acordo firmado com outro país, igual tratamento deverá ser estendido ao país signatário do primeiro acordo (cláusula da nação mais favorecida) ${ }^{299}$. É o caso, por exemplo, dos acordos dos Estados Unidos com Índia ${ }^{300}$ e China ${ }^{301}$.

A ineficácia do tax sparing também é sustentada nos Estados Unidos com base no já mencionado argumento de que, normalmente, as empresas americanas possuem excesso de créditos de impostos pagos no exterior, relativos a países estrangeiros nos quais a renda

\footnotetext{
${ }^{296}$ Cf. Harry A. Shannon III, op. cit. (nota 44), p. 88.

${ }^{297}$ Cf. Damian Laurey, op. cit. (nota 184), p. 490.

${ }^{298}$ Cf. Harry A. Shannon III, op. cit. (nota 44), p. 88.

${ }^{299}$ Cf. Richard Mitchell, op. cit. (nota 289), pp. 230-231.

${ }^{300}$ É o que consta da Troca de Notas entre Estados Unidos e República da Índia, que acompanha o acordo de bitributação celebrado entre os dois países, em vigor a partir de $1^{\circ}$ de janeiro de 1991: "Both sides agree that a tax sparing credit shall not be provided in Article 25 (Relief from Double Taxation) of the Convention at this time. However, the Convention shall be promptly amended to incorporate a tax sparing credit provision if the United States hereafter amends its laws concerning the provision of tax sparing credits or the United States reaches agreement on the provision of a tax sparing credit with any other country."

${ }^{301}$ Com efeito, é o que está disposto na Troca de Cartas que acompanha o acordo de bitributação celebrado entre os Estados Unidos e a República Popular da China, que entrou em vigor em $1^{\circ}$ de janeiro de 1987: "In letters signed at the same time as the rest of the Agreement, President Reagan and Premier Zhao confirm the understanding of the two governments with respect to the United States position on tax sparing credits. It is agreed that, if the United States amends its laws to authorize such credits or grants such a credit in a tax treaty with another country, the Agreement will be amended to incorporate such a credit. The amended Agreement would be subject to ratification."
} 
auferida foi tributada de forma mais gravosa do que o imposto incidente nos Estados Unidos sobre estes mesmos rendimentos ${ }^{302}$.

Assim, a tributação inferior nos países importadores de capital poderia ser compensada com créditos em excesso detidos pela empresa americana, de modo que o investidor norte-americano continuaria fruindo dos benefícios decorrentes do incentivo fiscal concedido pelo Estado da fonte ${ }^{303}$.

No entanto, como já apontado, tal alegação de fato somente se aplica em situações específicas, não sendo válida para a generalidade dos contribuintes que investem nos países em desenvolvimento ${ }^{304}$.

Outro questionamento levantado, baseado nas lições de Stanley S. Surrey, consiste na existência de dúvidas a respeito da efetividade dos incentivos fiscais nos quais se funda a concessão do tax sparing, relativos à promoção de investimentos estrangeiros no Estado da fonte. Desta forma, questionava-se por que razão os Estados Unidos apoiariam um incentivo aos investimentos de eficácia questionável ${ }^{305}$.

Ademais, aponta-se que o tax sparing conflitava com a política tributária estabelecida pelos Estados Unidos. Nesse sentido, o tax sparing seria mecanismo por meio do qual seria implementado um subsídio tributário e que, além disso, teria o efeito de reduzir as alíquotas efetivas aplicáveis nos Estados Unidos aos investidores que estivessem sujeitos ao acordo de bitributação. No entanto, a tributação nos Estados Unidos somente poderia ser estabelecida pela legislação interna, e nunca pelo acordo internacional (savings (clause) $)^{306}$.

Deve-se ressaltar que, a despeito de todas as críticas apontadas, a política dos Estados Unidos relativa às cláusulas de tax sparing é também recriminada por alguns autores daquele país que se propuseram a estudar o tema, os quais defendem que os Estados Unidos deveriam alterá-la ${ }^{307}$.

${ }^{302}$ Cf. H. David Rosenbloom, op. cit. (nota 295), pp. 19-20; Reuven S. Avi-Yonah, op. cit. (nota 279), p. 182.

${ }^{303}$ Cf. Kim Brooks, op. cit. (nota 48), pp. 512-513.

304 Cf. John Darcy. "The effect of tax-sparing on United States business in China". University of San Francisco Law Review. v. 21, 1987, pp. 402-405.

${ }^{305}$ Cf. Harry A. Shannon III, op. cit. (nota 44), p. 88; Yariv Brauner, op. cit. (nota 84), p. 123; Cristiane Coelho, op. cit. (nota 73), p. 688.

${ }^{306}$ Cf. Harry A. Shannon III, op. cit. (nota 44), p. 88; Lawrence D. Hollman, op. cit. (nota 289), p. 287.

${ }^{307}$ Cf. Damian Laurey, op. cit. (nota 184), p. 470; Patrick L. Kelley, op. cit. (nota 253), pp. 159-167. 
Nesse sentido, alega-se que o posicionamento adotado pelos Estados Unidos é injustificável, na medida em que não é seguido por nenhum outro país desenvolvido. Com isso, perdem em competitividade as empresas americanas que atuam no exterior, já que uma empresa multinacional sediada em país que conceda o tax sparing em seus acordos de bitributação com países em desenvolvimento terá uma vantagem competitiva, ao investir em tais países, frente às empresas americanas ${ }^{308}$. De fato, a empresa que puder se valer de acordo de bitributação que contenha cláusula de tax sparing pagará um montante menor a título de imposto, já que poderá aproveitar-se do crédito fictício ali previsto.

\subsubsection{O acordo de bitributação entre Brasil e Estados Unidos}

Embora as relações comerciais e de investimento entre Brasil e Estados Unidos encontrem-se em estágio avançado ${ }^{309}$, até os dias de hoje os dois países ainda não encontraram um consenso no que diz respeito à assinatura e ratificação de um acordo de bitributação. Aponta-se, assim, que o Brasil é o mais importante parceiro comercial dos Estados Unidos com o qual este último não possui acordo de bitributação ${ }^{310}$.

O ponto mais sensível nas negociações de um acordo de bitributação entre os dois países certamente reside na figura do tax sparing: enquanto o Brasil recusa-se a aceitar um acordo de bitributação com um país desenvolvido sem a inclusão da referida cláusula, os Estados Unidos mantêm sua já consolidada posição ${ }^{311}$ de jamais aprovar acordos em que esta cláusula esteja presente. O tax sparing pode ser considerado, assim, como o principal obstáculo à conclusão de um acordo de bitributação entre Brasil e Estados Unidos ${ }^{312}$, embora não seja o único ${ }^{313}$.

\footnotetext{
${ }^{308}$ Cf. Damian Laurey, op. cit. (nota 184), p. 469; Cristiane Coelho, op. cit. (nota 73), p. 689; Samuel C. Thompson Jr.. "The case for tax sparing along with expanding and limiting the Subpart F regime". The George Washington International Law Review. v. 35, 2003, p. 312.

${ }^{309}$ Sobre as relações entre Brasil e Estados Unidos, cf. Agostinho Toffoli Tavolaro, op. cit. (nota 89), p. 754.

${ }^{310}$ Cf. Yariv Brauner, op. cit. (nota 84), p. 109.

${ }^{311}$ Cf. Yariv Brauner, op. cit. (nota 84), p. 114.

${ }^{312}$ Cf. Richard Mitchell, op. cit. (nota 289), p. 222; Agostinho Toffoli Tavolaro, op. cit. (nota 89), p. 757.

${ }^{313}$ Mencione-se, nesse passo, a tributação na fonte dos serviços, o prazo mínimo para a configuração de um estabelecimento permanente e as regras brasileiras de preços de transferência. Cf. Yariv Brauner, op. cit. (nota 84), pp. 121-122.
} 
O primeiro acordo de bitributação dos Estados Unidos, celebrado com a França, é datado do ano de 1932. Tem-se que, já no início de 1949, Brasil e Estados Unidos iniciaram suas primeiras tratativas com a finalidade de se obter um acordo de bitributação entre os dois países ${ }^{314}$.

Como resultado, Brasil e Estados Unidos chegaram a assinar um acordo de bitributação em 13 de março de 1967. Este seria o terceiro acordo de bitributação do Brasil, que à época já tinha assinado acordos com o Japão (1965) e com a Suécia (1967), este último dois meses antes da assinatura do acordo com os Estados Unidos. Ainda, caso viesse a entrar em vigor, seria o referido acordo o primeiro dos Estados Unidos com um país latino-americano ${ }^{315}$.

À época da negociação do Acordo Brasil-Estados Unidos, o governo do então Presidente Lyndon Johnson opunha-se fortemente ao tax sparing ${ }^{316}$, cuja inclusão era contrária à posição dos Estados Unidos de não aprovar qualquer acordo de bitributação em que constasse tal cláusula, conforme o já mencionado ponto de vista defendido por Stanley S. Surrey ${ }^{317}$.

Conforme aponta Richard Mitchell, o Acordo Brasil-Estados Unidos previa mecanismo de tax sparing pouco usual ${ }^{318}$. Com efeito, o artigo $7^{\circ 319}$ do acordo assinado pelos dois países previa um crédito destinado aos investidores americanos que investissem no Brasil, equivalente a 7\% do montante investido no país em determinados tipos de bens.

\footnotetext{
${ }^{314}$ Cf. Richard Mitchell, op. cit. (nota 289), p. 222.

${ }^{315}$ Cf. Richard Mitchell, op. cit. (nota 289), p. 223.

${ }^{316}$ Cf. Cristiane Coelho, op. cit. (nota 73), p. 686.

${ }^{317}$ Cf. Luís Eduardo Schoueri, op. cit. (nota 75), p. 274.

${ }^{318}$ Cf. Richard Mitchell, op. cit. (nota 289), p. 223. Cf. também Yong Suk Oh, op. cit. (nota 280), p. 49.

319 “ARTIGO 7

CRÉDITO PARA INVESTIMENTO
}

1. Os Estados Unidos concederão a um investidor qualificado, em uma companhia qualificada, por conta dos impostos especificados no subparágrafo (1) (b) do Artigo (1), um crédito pelos investimentos efetuados no Brasil. O crédito concedido a um investidor qualificado será baseado em $7 \%$ do montante dos bens qualificados, postos em serviço pela companhia qualificada, durante o ano fiscal de tal companhia, para utilização exclusiva no Brasil, em um comércio ou negócio qualificado. O objetivo dêste dispositivo é estender aos investimentos efetuados no Brasil o crédito para investimento concedível aos investimentos efetuados nos Estados Unidos. A expressão ‘bens qualificados' incluirá, de modo geral, propriedade tangível depreciável, quer seja propriedade pessoal ou seja usada como parte integrante de processos industriais, de transportes, comunicações ou outros quaisquer semelhantes, ou como uma instalação qualquer de pesquisa ou armazenagem para aqueles fins (mas não incluirá um prédio e seus componentes estruturais). Entretanto, em hipótese alguma o montante do crédito poderá exceder a menor das seguintes importâncias:

(a) $7 \%$ do novo investimento líquido do investidor qualificado na companhia qualificada; ou

(b) o montante dos bens dos Estados Unidos adquiridos pela companhia qualificada, durante o ano fiscal no qual tenham sido postos em serviço os bens para os quais os créditos fôr concedido, ou durante o ano fiscal precedente e atribuído ao investidor qualificado. (...)" 
O objetivo desta cláusula, conforme disposto em seu próprio texto, era o de "estender aos investimentos efetuados no Brasil o crédito para investimento concedível aos investimentos efetuados nos Estados Unidos".

Nota-se, assim, que o crédito para investimentos previsto no artigo $7^{\circ}$ do acordo assinado entre Brasil e Estados Unidos não correspondia, exatamente, a cláusula de tax sparing, na medida em que se tratava de crédito totalmente desvinculado de qualquer legislação brasileira concessiva de incentivos fiscais.

Tampouco há perfeita identidade entre o disposto no artigo $7^{\circ}$ e o matching credit, uma vez que, embora o crédito de $7 \%$ esteja prefixado no próprio texto do acordo de bitributação, esta porcentagem não corresponde ao imposto considerado pago no Brasil sobre os rendimentos ali auferidos, variando em função do capital aportado no País para a realização de determinados tipos de investimento em bens qualificados.

O crédito em comento parece, na realidade, corresponder ao que Alberto Xavier menciona como crédito por investimento, o qual consiste na possibilidade de uma dedução imediata, do imposto devido no Estado da residência, de uma parcela do investimento efetivamente realizado no exterior ${ }^{320}$.

De qualquer forma, como também aponta Alberto Xavier, o crédito por investimento é, assim como o tax sparing e o matching credit, modalidade pela qual os países desenvolvidos, exportadores de capital, favorecem os investimentos em países em desenvolvimento, importadores de capital $^{321}$. Trata-se, com efeito, do tipo de dispositivo que é sistematicamente rechaçado pelos Estados Unidos.

Em 1968, o Comitê de Relações Exteriores do Senado americano, em sessão executiva, analisou a conveniência da aprovação do acordo celebrado com o Brasil, rejeitando-o em função da cláusula de crédito por investimento ${ }^{322}$, normalmente referida como sendo de tax sparing.

\footnotetext{
${ }^{320}$ Cf. Alberto Xavier, op. cit. (nota 5), p. 828.

${ }^{321}$ Cf. Alberto Xavier, op. cit. (nota 5), p. 828.

${ }^{322}$ Cf. Yong Suk Oh, op. cit. (nota 280), p. 49.
} 
Nos anos seguintes à rejeição do texto do Acordo Brasil-Estados Unidos, houve diversas tentativas de negociação entre os dois países. Nesse passo, afirmou Francisco Oswaldo Neves Dornelles, em texto publicado no jornal Folha de S. Paulo ${ }^{323}$ :

\begin{abstract}
"No período de 1970 a 1984, várias negociações foram desenvolvidas com os EUA visando a assinatura de acordo para evitar a dupla tributação de renda. Não foram concluídas pois esse país nunca aceitou conceder ao Brasil o mesmo tratamento fiscal -isenção e crédito fictícioconcedido pelos países exportadores de capital antes mencionados. Acresce ainda o fato de que, como a legislação norte-americana concede, de forma unilateral, um crédito pelo imposto pago no Brasil, não existe dupla tributação da renda entre os dois países de modo a prejudicar o fluxo de investimentos."
\end{abstract}

Parece pouco provável que o Brasil ou os Estados Unidos venham a mudar suas posições no que diz respeito ao tax sparing ${ }^{324}$. Os Estados Unidos, em razão de sua firme política nesse sentido, e também pelo fato de que a aceitação de uma cláusula de tax sparing em acordo de bitributação com o Brasil implicaria, como já mencionado, a revisão de diversos acordos previamente celebrados ${ }^{325}$. A posição do Brasil a respeito da matéria será discutida em maiores detalhes no capítulo seguinte.

\title{
4.2. A acolhida internacional das cláusulas de tax sparing e matching credit
}

A posição dos Estados Unidos, contrária ao tax sparing, está consolidada desde o final da década de 1950, sendo amplamente conhecida por seus parceiros na negociação de acordos de bitributação.

Sabe-se, no entanto, que a partir da década de 1960, os demais países desenvolvidos passaram a negociar diversos acordos de bitributação com países em desenvolvimento contendo cláusulas de tax sparing e matching credit, em uma clara demonstração de que eram favoráveis à concessão de tais cláusulas.

${ }^{323}$ Cf. Francisco Oswaldo Neves Dornelles. "Acordo fiscal Brasil-EUA". Folha de S. Paulo. São Paulo, 28 de outubro, 2007. Disponível em: <http://www1.folha.uol.com.br/fsp/opiniao/fz2810200709.htm>. Acesso em: 20 de novembro de 2012.

${ }^{324}$ Cf. Cristiane Coelho, op. cit. (nota 73), p. 697.

${ }^{325}$ Cf. Agostinho Toffoli Tavolaro, op. cit. (nota 89), pp. 764-765. 
Não obstante, no Relatório da OCDE, de 1998, apontou-se que muitos dos Estados membros, e até mesmo Estados não membros, mostravam-se desapontados com a aplicação das cláusulas de tax sparing, o que justificaria o clamor da Organização pela reconsideração do mecanismo ${ }^{326}$.

Criticando a alegação da OCDE de que a concessão do tax sparing estaria sob revisão em seus Estados membros e nos Estados não membros, Luís Eduardo Schoueri aponta que não há evidências empíricas de resultados negativos com o tax sparing, e que a sua mera continuidade deve ser entendida como indicativo da existência de bons resultados 327 .

Corroborando este entendimento, mencione-se que, em estudo publicado em janeiro de 2003, Victor Thuronyi analisou os acordos de bitributação celebrados a partir do ano 2000, de modo a verificar as práticas que vinham sendo adotadas pelos países após a publicação do Relatório da OCDE. A conclusão do autor é a de que o tax sparing estava presente em um terço dos tratados por ele analisados, sendo que metade deles foi celebrada por Estados membros da $\mathrm{OCDE}^{328}$.

Não obstante tal conclusão, é possível notar que, após a publicação do Relatório da OCDE, alguns de seus Estados membros que tinham por política adotar as cláusulas de tax sparing, como Canadá e Austrália, passaram a deixar de fazê-lo em seus novos acordos de bitributação com países em desenvolvimento ${ }^{329}$.

De outra parte, alguns dos países em desenvolvimento que costumavam pleitear a inclusão de cláusulas de tax sparing na negociação de seus acordos de bitributação não mais adotam esta prática, diante da recusa dos países desenvolvidos em concordar com as mencionadas cláusulas, o que se torna um impasse para a conclusão de novos acordos.

Para verificar tais assertivas, passa-se a analisar as recentes posições de alguns países selecionados, desenvolvidos e em desenvolvimento, no tocante às cláusulas de tax sparing e matching credit.

\footnotetext{
${ }^{326}$ Cf. OCDE, op. cit. (nota 1), p. 12; Deborah Toaze, op. cit. (nota 175), p. 890.

${ }^{327}$ Cf. Luís Eduardo Schoueri, op. cit. (nota 40), p. 100.

${ }^{328}$ Cf. Victor Thuronyi. "Recent treaty practice on tax sparing". Tax Notes International. v. 29, n. 3, janeiro, 2003, pp. 301-302.

${ }^{329}$ Cf. Kim Brooks, op. cit. (nota 48), pp. 528-529.
} 


\subsubsection{As cláusulas de tax sparing e matching credit em países desenvolvidos}

A Austrália já chegou a incluir cláusulas de tax sparing em quatorze acordos de bitributação. Contudo, com exceção do Acordo Austrália-Filipinas, que atualmente é o único que contém cláusula de tax sparing vigente, em todos os demais acordos as mencionadas cláusulas valeram somente durante um período de tempo determinado ${ }^{330}$.

O Canadá sempre teve por política adotar cláusulas de tax sparing nos acordos de bitributação celebrados com em desenvolvimento ${ }^{331}$. A cláusula está presente em aproximadamente um terço de seus acordos, sendo possível citar, como exemplos, os acordos celebrados com Barbados, Malásia, Marrocos e Paquistão ${ }^{332}$.

Contudo, seu posicionamento mais recente é de que, de um modo geral, não mais serão assinados acordos de bitributação com cláusulas de tax sparing, sendo que, nas hipóteses excepcionais em que a cláusula for concedida, será por um curto período de tempo (sunset clause) ${ }^{333}$.

Também a França possui diversos acordos de bitributação com países em desenvolvimento que possuem cláusulas de tax sparing. É o caso dos acordos com China, Etiópia, Gana, Indonésia, Irã, Jamaica, Jordânia, Paquistão e Vietnã. No Acordo BrasilFrança, há previsão de cláusula de matching credit, a qual foi objeto de questionamento perante o Conseil d'État francês. Tal decisão será analisada em maiores detalhes no próximo capítulo, quando serão examinadas algumas das cláusulas de tax sparing e matching credit previstas nos acordos de bitributação brasileiros ${ }^{334}$.

A Alemanha, tradicionalmente, teve sempre por política concordar com a concessão de cláusulas de matching credit, como forma de promoção de investimentos em países em

\footnotetext{
${ }^{330}$ Cf. Kathrin Bain, Richard Krever e Amanda O’Connor. "Australia”. LANG, Michael; PISTONE, Pasquale; SCHUCH, Josef; STARINGER, Claus (editores). The impact of the OECD and the UN Model Conventions on bilateral tax treaties. Cambridge: Cambridge University, 2012, pp. 100-101.

${ }^{331}$ Cf. Alexander J. Easson, op. cit. (nota 99), p. 521.

332 Cf. Catherine Brown e Martha O’Brien. "Canada". LANG, Michael; PISTONE, Pasquale; SCHUCH, Josef; STARINGER, Claus (editores). The impact of the OECD and the UN Model Conventions on bilateral tax treaties. Cambridge: Cambridge University, 2012, p. 224.

${ }_{333}$ Cf. Kim Brooks, op. cit. (nota 48), p. 530.

${ }^{334}$ Cf. Hugues Perdriel Vaissière e Emmanuel Raingeard de la Blétière. "France". LANG, Michael; PISTONE, Pasquale; SCHUCH, Josef; STARINGER, Claus (editores). The impact of the OECD and the UN Model Conventions on bilateral tax treaties. Cambridge: Cambridge University, 2012, p. 459.
} 
desenvolvimento ${ }^{335}$. Não obstante, tal postura tem se alterado nos últimos anos, haja vista o reconhecimento da Alemanha de que o atual nível de desenvolvimento econômico de muitos países que, nas décadas de 1960 e 1970, eram tidos como países em desenvolvimento, não mais justifica a concessão de cláusulas desse tipo. A denúncia do Acordo Brasil-Alemanha, que será analisada adiante, é sintomática da nova política que vem sendo adotada pelas autoridades tributárias alemãs ${ }^{336}$.

Dentre os países desenvolvidos, o Reino Unido destacou-se, desde o princípio, como um dos maiores entusiastas das cláusulas de tax sparing, sendo inclusive o primeiro a aventar a discussão a respeito da introdução deste mecanismo em seus acordos de bitributação $^{337}$.

É interessante notar que, além das cláusulas de tax sparing presentes nos acordos de bitributação com países em desenvolvimento, o Reino Unido também possuía cláusulas do gênero em acordos antigos celebrados com países membros da OCDE, como é o caso de Portugal e Espanha ${ }^{338}$.

Contudo, a atual política adotada é de apenas concordar com cláusulas de tax sparing nos acordos de bitributação com países em desenvolvimento, as quais certamente serão previstas por período limitado (sunset clauses) ou com relação a uma fonte de rendimentos em particular ${ }^{339}$.

A Espanha já assinou diversos acordos contendo cláusulas de tax sparing e matching credit. Originalmente, estas cláusulas beneficiavam empresas estrangeiras investindo na Espanha, sendo que, em um segundo momento, passaram a ter o sentido inverso, qual seja, o de beneficiar empresas espanholas investindo no exterior. Assim é que hoje se encontram vigentes na Espanha cláusulas de tax sparing e matching credit tanto

\footnotetext{
${ }^{335}$ Cf. Steffen Lampert. "Germany”. LANG, Michael; PISTONE, Pasquale; SCHUCH, Josef; STARINGER, Claus (editores). The impact of the OECD and the UN Model Conventions on bilateral tax treaties. Cambridge: Cambridge University, 2012, p. 493; Harry A. Shannon III, op. cit. (nota 44), pp. 88-89.

336 Cf. Gerd Willi Rothmann. "A denúncia do Acordo de Bitributação Brasil-Alemanha e suas conseqüências". ROCHA, Valdir de Oliveira (coord.). Grandes questões atuais do Direito Tributário. v. 9. São Paulo: Dialética, 2005, p. 147.

${ }^{337}$ Cf. UNITED STATES SENATE, op. cit. (nota 124), pp. 7-8.

${ }^{338}$ Cf. Brian Cleave. "The UK". LANG, Michael; PISTONE, Pasquale; SCHUCH, Josef; STARINGER, Claus (editores). The impact of the OECD and the UN Model Conventions on bilateral tax treaties. Cambridge: Cambridge University, 2012, p. 1.138.

${ }^{339}$ Cf. Brian Cleave, op. cit. (nota 338), p. 1.138.
} 
com países desenvolvidos (e.g., Canadá, Alemanha, Suécia, Suíça) quanto com países em desenvolvimento (e.g., Brasil ${ }^{340}$, Cuba, México, Filipinas, Tailândia) ${ }^{341}$.

Nos acordos de bitributação espanhóis mais recentes, tem-se seguido a orientação da OCDE de adotar as mencionadas cláusulas em situações mais específicas, evitando-se a utilização de cláusulas gerais ${ }^{342}$.

Na Noruega, a prática de negociar alguns acordos de bitributação com países em desenvolvimento contendo cláusulas de tax sparing (Estônia, Índia, Nepal, Tailândia e Vietnã) tem sido encarada com maior relutância, em razão das novas recomendações da OCDE. De um modo geral, as cláusulas de tax sparing presentes nos acordos noruegueses possuem duração limitada, pelo período de dez anos (sunset clauses) ${ }^{343}$.

O atual posicionamento da Holanda, que possui cláusulas de tax sparing e matching credit com países em desenvolvimento, é o de não negociar novos acordos com os referidos mecanismos, bem como renegociar os antigos acordos que os contenham ${ }^{344}$.

Por fim, deve-se apontar que em alguns dos acordos de bitributação celebrados pela a Suécia com países em desenvolvimento, tais como o Brasil, também existe a previsão de cláusulas de matching credit. Não obstante, como relata Martin Berglund, a recente prática sueca tem sido de evitar cláusulas gerais de matching credit, preferindo-se a adoção de mecanismos de auxílio a atividades específicas, como a manufatura e o turismo ${ }^{345}$.

Ante o exposto, nota-se que de fato existe um clima de relutância entre os países desenvolvidos no que diz respeito à assinatura de novos acordos de bitributação com países em desenvolvimento que contenham cláusulas de tax sparing. Em muitos casos, o

\footnotetext{
${ }^{340}$ O Acordo Brasil-Espanha, que possui cláusula de matching credit recíproca, será analisado com maiores detalhes no próximo capítulo.

${ }^{341}$ Cf. F. Alfredo García Prats. "Spain". LANG, Michael; PISTONE, Pasquale; SCHUCH, Josef; STARINGER, Claus (editores). The impact of the OECD and the UN Model Conventions on bilateral tax treaties. Cambridge: Cambridge University, 2012, p. 1048.

${ }^{342}$ Cf. F. Alfredo García Prats, op. cit. (nota 341), p. 1048.

${ }^{343}$ Cf. Eivind Furuseth. "Norway". LANG, Michael; PISTONE, Pasquale; SCHUCH, Josef; STARINGER, Claus (editores). The impact of the OECD and the UN Model Conventions on bilateral tax treaties. Cambridge: Cambridge University, 2012, pp. 790-791.

${ }^{344}$ Cf. Tanja Bender, Irene Burgers e Faustina Peters. "The Netherlands". LANG, Michael; PISTONE, Pasquale; SCHUCH, Josef; STARINGER, Claus (editores). The impact of the OECD and the UN Model Conventions on bilateral tax treaties. Cambridge: Cambridge University, 2012, p. 725.

${ }^{345}$ Cf. Martin Berglund. "Sweden”. LANG, Michael; PISTONE, Pasquale; SCHUCH, Josef; STARINGER, Claus (editores). The impact of the OECD and the UN Model Conventions on bilateral tax treaties. Cambridge: Cambridge University, 2012, pp. 1.077-1.078.
} 
posicionamento da OCDE acerca do assunto parece decisivo para a mudança de abordagem dos países analisados.

\subsubsection{As cláusulas de tax sparing e matching credit em países em desenvolvimento}

A Argentina possui cláusulas de tax sparing em seus acordos de bitributação com Canadá, Dinamarca, Finlândia, Noruega, Suécia e Reino Unido ${ }^{346}$. Havia cláusula dessa natureza também no Acordo Argentina-Espanha, mas este foi denunciado pela Argentina e perdeu sua eficácia em 01/01/2013 ${ }^{347}$.

O tax sparing não faz parte da política de negociação de acordos de bitributação do Chile, que apenas possui as referidas cláusulas em seus acordos com a Malásia e com a Tailândia, em favor desses países. Trata-se de cláusulas bastante específicas e direcionadas, que foram incluídas em razão de o tax sparing ser ponto fundamental para a negociação dos acordos com Malásia e Tailândia ${ }^{348}$. Assim, embora o Chile seja também um país em desenvolvimento, em seus únicos acordos que contêm cláusula de tax sparing, o papel assumido é o de Estado da residência do investidor estrangeiro.

Por outro turno, a Colômbia tem adotado como política requerer a inclusão de cláusulas de tax sparing nos acordos de bitributação que negocia. No entanto, diante da recusa de muitos países desenvolvidos em concordar com o tax sparing, a equipe de negociações da Colômbia tem flexibilizado essa posição, de modo que atualmente as cláusulas de tax sparing e matching credit não são consideradas essenciais para fins de conclusão de um acordo de bitributação ${ }^{349}$.

346 Cf. Axel A. Verstraeten. "Argentina". LANG, Michael; PISTONE, Pasquale; SCHUCH, Josef; STARINGER, Claus (editores). The impact of the OECD and the UN Model Conventions on bilateral tax treaties. Cambridge: Cambridge University, 2012, p. 61.

${ }^{347}$ Cf. Francisco Peregil. "Argentina rompe su acuerdo fiscal con España que evitaba la doble imposición". El País. Buenos Aires, 14 de julho, 2012. Disponível em: <http://economia.elpais.com/economia/2012/07/14/actualidad/1342216880_042551.html>. Acesso em: 08 de setembro de 2012.

${ }^{348}$ Cf. José Madariaga Montes e Felipe Yáñez Villanueva. "Chile”. LANG, Michael; PISTONE, Pasquale; SCHUCH, Josef; STARINGER, Claus (editores). The impact of the OECD and the UN Model Conventions on bilateral tax treaties. Cambridge: Cambridge University, 2012, pp. 253-254.

349 Cf. Natalia Quiñones Cruz. "Colombia". LANG, Michael; PISTONE, Pasquale; SCHUCH, Josef; STARINGER, Claus (editores). The impact of the OECD and the UN Model Conventions on bilateral tax treaties. Cambridge: Cambridge University, 2012, p. 305; Jose Andrés Romero, op. cit. (nota 48), p. 366. 
Ainda na esteira dos países latino-americanos, deve-se notar que o Peru não possui cláusulas de tax sparing ou matching credit em nenhum de seus acordos de bitributação ${ }^{350}$.

No que concerne à Coreia do Sul, Sung Keun Choi relata, em artigo publicado nos Cahiers de Droit Fiscal International da International Fiscal Association em $1998^{351}$, que até o ano de 1986 não havia, na legislação interna coreana, nenhum dispositivo que expressamente previsse o tax sparing, de modo que esta modalidade de crédito não era reconhecida.

Contudo, em 1986, no Regulation of Tax Reduction and Exemption Act, reconheceu-se a possibilidade de creditamento também no que concerne aos tributos que foram objeto de reduções ou isenções no outro Estado com o qual a Coreia do Sul tenha celebrado acordo de bitributação ${ }^{352}$.

Em determinados acordos de bitributação, a Coreia do Sul concedeu o tax sparing no que diz respeito aos investimentos de empresas coreanas no exterior, i.e., na posição de Estado da residência do investidor ${ }^{353}$. De outra parte, também é possível encontrar cláusulas de tax sparing nos acordos coreanos celebrados com países desenvolvidos (com exceção dos Estados Unidos), como forma de preservar as reduções e incentivos fiscais concedidos pela Coreia com a finalidade de atrair investimentos estrangeiros ${ }^{354}$. Trata-se, assim, de cláusulas em que a Coreia do Sul figura como fonte dos rendimentos.

A Índia figura entre os maiores defensores das cláusulas de tax sparing, assim como o Brasil ${ }^{355}$. Nos acordos celebrados com países desenvolvidos, o tax sparing tende a ser unilateral. É o caso dos acordos indianos com Austrália, Bélgica, Canadá, Dinamarca, França, Irlanda, Países Baixos, Reino Unidos, dentre outros ${ }^{356}$.

350 Cf. Cecilia Delgado Ratto. "Peru". LANG, Michael; PISTONE, Pasquale; SCHUCH, Josef; STARINGER, Claus (editores). The impact of the OECD and the UN Model Conventions on bilateral tax treaties. Cambridge: Cambridge University, 2012, p. 814.

${ }^{351}$ Cf. Sung Keun Choi. "Korea, Republic of". Cahiers de Droit Fiscal International. Practical issues in the application of double tax conventions. v. LXXXIIIb. The Hague: Kluwer Law International, 1998, p. 485.

${ }^{352}$ Cf. Sung Keun Choi, op. cit. (nota 351), p. 485.

${ }^{353}$ É o caso dos acordos da Coreia com Singapura, Malásia, Bangladesh, Filipinas, Sri Lanka, Índia, Turquia, Egito, Indonésia, Nigéria, México, Vietnã, dentre outros. Cf. Sung Keun Choi, op. cit. (nota 351), p. 485.

${ }_{354}$ Cf. Sung Keun Choi, op. cit. (nota 351), p. 485.

355 Cf. Pasquale Pistone. "General report". LANG, Michael; PISTONE, Pasquale; SCHUCH, Josef; STARINGER, Claus (editores). The impact of the OECD and the UN Model Conventions on bilateral tax treaties. Cambridge: Cambridge University, 2012, p. 30.

${ }^{356}$ Cf. D. P. Sengupta. "India". LANG, Michael; PISTONE, Pasquale; SCHUCH, Josef; STARINGER, Claus (editores). The impact of the OECD and the UN Model Conventions on bilateral tax treaties. Cambridge: Cambridge University, 2012, pp. 591-592. 
Já nos acordos com países em desenvolvimentos, as cláusulas tendem a ser mútuas ou recíprocas, sendo notável a rede de acordos de bitributação que a Índia possui com cláusulas desta natureza. Mencione-se, nesse sentido, os acordos com Bangladesh, Brasil, China, Indonésia, Israel, Singapura, Tailândia e Vietnã, entre tantos outros ${ }^{357}$.

Finalmente, analisando-se o caso da China, é de se notar que o país, assim como Brasil e Índia, figurava como um defensor das cláusulas de tax sparing e matching credit, haja vista sua posição de país em desenvolvimento. Nesse sentido, o país é signatário de diversos acordos contendo as referidas cláusulas, em bases unilaterais ou recíprocas ${ }^{358}$.

No entanto, conforme descrito por Wei Cui, seria um erro alegar que a China invariavelmente busca negociar cláusulas de tax sparing e matching credit em seus acordos de bitributação. Prova disso, na visão do autor, reside no fato de que, em seus acordos mais recentes, normalmente não há previsão de tais mecanismos, assim como nas revisões de alguns de seus acordos antigos (e.g., Bélgica e Finlândia) ${ }^{359}$.

Wei Cui relata que essa política recente de não adoção do tax sparing é consistente com o abandono, pela China, de boa parte de seus incentivos fiscais voltados à atração de investimentos estrangeiros, e com o fato de que o país deixou de ser considerado como "país em desenvolvimento", para fins de aplicação das cláusulas de tax sparing ${ }^{360}$, certamente por conta dos impressionantes índices de crescimento econômico verificados nos últimos anos.

Analisando-se a postura mais recente dos países em desenvolvimento em tela no tocante às cláusulas de tax sparing e matching credit, nota-se que, por um lado, há aqueles que se mantiveram firmes em sua postura favorável em relação a tais cláusulas, como é o caso da Índia (e também do Brasil, cuja política será analisada no próximo capítulo), e de outra parte, há aqueles que parecem abdicar de antigo posicionamento favorável, como é o caso da Colômbia, que não deseja que discussões sobre o tax sparing tornem-se um entrave às negociações, e da China, que não mais se encontraria na posição de "país em

\footnotetext{
${ }^{357}$ Cf. D. P. Sengupta, op. cit. (nota 356), pp. 591-592.

${ }^{358}$ Cf. Wei Cui. "China”. LANG, Michael; PISTONE, Pasquale; SCHUCH, Josef; STARINGER, Claus (editores). The impact of the OECD and the UN Model Conventions on bilateral tax treaties. Cambridge: Cambridge University, 2012, pp. 287-288.

${ }^{359}$ Cf. Wei Cui, op. cit. (nota 358), p. 288.

${ }^{360}$ Cf. Wei Cui, op. cit. (nota 358), p. 288.
} 
desenvolvimento", a demandar a utilização de tal mecanismo. Há, ainda, os países que não possuem por política a adoção das cláusulas de tax sparing, tais como Chile e Peru. 


\section{OS ACORDOS DE BITRIBUTAÇÃO BRASILEIROS E AS CLÁUSULAS DE TAX SPARING E MATCHING CREDIT}

\subsection{A posição brasileira a respeito das cláusulas de tax sparing e matching credit}

Para alguns países em desenvolvimento, o tax sparing é questão crucial na negociação de acordos de bitributação com países desenvolvidos, sem a qual não se chega a um consenso. O reconhecimento desta realidade faz com que muitos países desenvolvidos, mesmo que contrariados, acabem por assinar acordos de bitributação com cláusulas de tax sparing e matching credit $^{361}$.

Essa parece ser exatamente a situação do Brasil, ao negociar acordos de bitributação com países desenvolvidos: o País, desde a negociação de seus primeiros acordos de bitributação, sempre teve por princípio adotar cláusulas visando a impedir que os benefícios fiscais eventualmente concedidos com a finalidade de atrair investimentos estrangeiros fossem anulados, com a transferência da respectiva receita tributária para o Estado da residência do investidor.

Desta forma, a adoção de cláusulas de tax sparing e matching credit é uma constante para o Brasil quando da negociação de acordos de bitributação com países desenvolvidos e, como se notará, também com alguns países em desenvolvimento ${ }^{362}$.

Francisco Oswaldo Neves Dornelles, que atualmente exerce o cargo de Senador da República, é considerado como um dos responsáveis pelo posicionamento adotado pela Administração Tributária brasileira até o presente momento ${ }^{363}$. Afinal, este já ocupou

\footnotetext{
${ }^{361}$ Cf. OCDE, op. cit. (nota 1), pp. 19-20.

${ }^{362}$ A esse respeito, cf. Luís Eduardo Schoueri e Natalie Matos Silva. "Brazil". LANG, Michael; PISTONE, Pasquale; SCHUCH, Josef; STARINGER, Claus (editores). The impact of the OECD and the UN Model Conventions on bilateral tax treaties. Cambridge: Cambridge University, 2012, pp. 197-199.

${ }^{363}$ Em defesa de seu entendimento, Francisco Oswaldo Neves Dornelles afirmou, em discurso proferido em 2003, na Câmara dos Deputados: "A inclusão das cláusulas de isenção e tax sparing nas convenções fiscais internacionais celebradas pelo Brasil reveste-se de fundamental importância, já que são esses os mecanismos garantidores de que qualquer incentivo, subsídio, isenção ou redução do imposto brasileiro significará efetivo benefício para o investidor e não uma mera transferência de recursos do Tesouro brasileiro para o do outro país." Cf. Francisco Oswaldo Neves Dornelles. "Acordo Brasil / Ucrânia para Eliminar a Dupla Tributação da Renda". Discurso proferido pelo Deputado FRANCISCO DORNELLES (PP/RJ), na Sessão da Câmara dos Deputados de 27 de novembro de 2003. Disponível em: <http://migre.me/cUs2f $>$. Acesso em: 30 de setembro de 2012.
} 
diversas posições de destaque, tais como Procurador Geral da Fazenda, líder da negociação de tratados internacionais, Secretário da Receita Federal e Ministro da Fazenda, de modo que seu pensamento influencia, ainda hoje, o pensamento dos membros da Administração responsáveis pela negociação dos acordos de bitributação brasileiros ${ }^{364}$.

A este respeito, cumpre ainda mencionar que o Brasil expressamente manifestou-se favoravelmente às cláusulas de tax sparing e matching credit na seção Position of nonmember countries dos Comentários ao artigo 23 da Convenção Modelo da $\mathrm{OCDE}^{365}$.

Inicialmente, o Brasil ${ }^{366}$ reserva para si o direito de incluir cláusulas de tax sparing relacionadas aos incentivos fiscais previstos em sua legislação interna ${ }^{367}$. No mesmo passo, o Brasil manifesta a posição de que incluirá cláusulas de matching credit em relação aos rendimentos previstos nos artigos 11 (juros) e 12 (royalties) da Convenção Modelo da OCDE, as quais corresponderão a percentuais do rendimento bruto ${ }^{368}$. Por fim, o País ${ }^{369}$ assegura que os dividendos, os quais estão sujeitos ao artigo 10 da Convenção Modelo da OCDE, terão direito a isenção ou a matching credit no outro Estado contratante ${ }^{370}$.

De fato, no contexto brasileiro, as cláusulas de tax sparing e matching credit são estabelecidas com relação aos rendimentos passivos (dividendos, juros e royalties). Por outro lado, nos termos da legislação brasileira, os dividendos distribuídos, para residentes ou não residentes, são isentos ${ }^{371}$, e os juros e royalties sujeitam-se, como regra, à alíquota de $15 \%$ na fonte, quando remetidos para o exterior ${ }^{372}$.

\footnotetext{
${ }^{364}$ Cf. Agostinho Toffoli Tavolaro, op. cit. (nota 89), pp. 763-764.

365 Cf. Comentários ao artigo 23 da Convenção Modelo da OCDE, Position of non-member countries.

366 Ao lado de Albânia, Argentina, China, Índia, Costa do Marfim, Malásia, Marrocos, Sérvia, Tailândia, Tunísia e Vietnã.

367 Cf. Comentários ao artigo 23 da Convenção Modelo da OCDE, Position of non-member countries, parágrafo $1^{\circ}$.

368 Cf. Comentários ao artigo 23 da Convenção Modelo da OCDE, Position of non-member countries, parágrafo $2^{\circ}$.

${ }_{369}$ Ao lado da Tunísia.

${ }^{370}$ Cf. Comentários ao artigo 23 da Convenção Modelo da OCDE, Position of non-member countries, parágrafo $3^{\circ}$.

${ }^{371}$ Cf. caput do artigo 10 da Lei $n^{\circ}$ 9.249/95: “Art. 10. Os lucros ou dividendos calculados com base nos resultados apurados a partir do mês de janeiro de 1996, pagos ou creditados pelas pessoas jurídicas tributadas com base no lucro real, presumido ou arbitrado, não ficarão sujeitos à incidência do imposto de renda na fonte, nem integrarão a base de cálculo do imposto de renda do beneficiário, pessoa física ou jurídica, domiciliado no País ou no exterior."

${ }^{372}$ Cf. artigos 685, 702 e 710 do Regulamento do Imposto de Renda (Decreto no $3.000 / 99$ ):

"Art. 685. Os rendimentos, ganhos de capital e demais proventos pagos, creditados, entregues, empregados ou remetidos, por fonte situada no País, a pessoa física ou jurídica residente no exterior, estão sujeitos à incidência na fonte (Decreto-Lei $n^{\circ} 5.844$, de 1943, art. 100, Lei $\mathrm{n}^{\mathrm{o}} 3.470$, de 1958, art. 77, Lei $\mathrm{n}^{\circ}$ 9.249, de 1995, art. 23, e Lei ${ }^{\circ} 9.779$, de 1999 , arts. $7^{\circ}$ e $8^{\circ}$ ):

I - à alíquota de quinze por cento, quando não tiverem tributação específica neste Capítulo, inclusive: (...)”
} 
Em razão da política aparentemente irredutível adotada pelo Brasil com relação a este assunto, atualmente o País é visto como um dos principais defensores das cláusulas de tax sparing e matching credit, ao lado da Índia e em oposição aos Estados Unidos ${ }^{373}$.

\subsection{Histórico das cláusulas de tax sparing e maching credit nos acordos de bitributação celebrados pelo Brasil}

Os primeiros acordos de bitributação celebrados pelo Brasil, promulgados em 1967, tiveram por parceiros a Suécia e o Japão. A escolha dos dois países não parece ter sido aleatória, uma vez que ambos já haviam concordado com a inclusão de cláusulas de tax sparing e matching credit em acordos de bitributação anteriores, em claro indicativo de que partilhavam do entendimento dos negociadores brasileiros a respeito da matéria ${ }^{374}$.

Com efeito, Francisco Oswaldo Neves Dornelles, que participou das negociações de grande parte dos acordos de bitributação brasileiros, aponta que o objetivo perseguido pelo Brasil na celebração dos primeiros acordos era o de recorrer o capital estrangeiro para completar seu desenvolvimento econômico. Nesse sentido, foram inseridas em tais acordos cláusulas que estimulavam o investimento no Brasil, e ao mesmo tempo impediam que os incentivos fiscais concedidos aos investidores estrangeiros fossem transferidos ao Estado da residência ${ }^{375}$.

Assim, tal como mencionado por Luís Eduardo Schoueri, nesse primeiro estágio da política de negociação de acordos de bitributação, que abrange o final da década de 1960 e a década de 1970, o Brasil buscou como parceiros justamente os países desenvolvidos, que pudessem no País investir, conforme as diretrizes traçadas pelo regime militar ${ }^{376}$.

\footnotetext{
“Art. 702. Estão sujeitas à incidência do imposto na fonte, à alíquota de quinze por cento, as importâncias pagas, creditadas, entregues, empregadas ou remetidas a beneficiários residentes ou domiciliados no exterior, por fonte situada no País, a título de juros, comissões, descontos, despesas financeiras e assemelhadas (Decreto-Lei ${ }^{\circ}$ 5.844, de 1943, art. 100, Lei n ${ }^{\circ} 3.470$, de 1958, art. 77, e Lei ${ }^{\circ}$ 9.249, de 1995, art. 28)."

“Art. 710. Estão sujeitas à incidência na fonte, à alíquota de quinze por cento, as importâncias pagas, creditadas, entregues, empregadas ou remetidas para o exterior a título de royalties, a qualquer título (Medida Provisória ${ }^{\circ}$ 1.749-37, de 1999, art. $3^{\circ}$ )."

${ }^{373}$ Cf. Pasquale Pistone, op. cit. (nota 355), p. 30.

${ }^{374}$ Cf. Luís Eduardo Schoueri, op. cit. (nota 75), pp. 271-272.

${ }^{375}$ Cf. Francisco Oswaldo Neves Dornelles. "Acordos para eliminar a Dupla Tributação". Revista de Direito Tributário. ano 2, n. 3, janeiro/março, 1978, pp. 251-255.

${ }^{376}$ Cf. Luís Eduardo Schoueri, op. cit. (nota 75), pp. 269-273.
} 
Nessa etapa inicial, não se concordaria com a assinatura de um acordo de bitributação com países desenvolvidos que não contivesse cláusula de tax sparing ou matching credit, em razão do entendimento de que os incentivos fiscais concedidos aos investidores estrangeiros deveriam reverter-se em benefícios somente para estes, e não para o Estado da residência ${ }^{377}$.

Em um segundo estágio da política brasileira de negociação de acordos, já na década de 1980, o Brasil passou a ter como parceiros, além dos países desenvolvidos, também países em desenvolvimento, muitos deles localizados na América Latina ${ }^{378}$.

Em tal fase, em função dos fluxos de rendimentos equânimes entre os Estados contratantes, as cláusulas de tax sparing e matching credit não se mostravam indispensáveis, devendo-se notar, de qualquer forma, que no período foram celebrados acordos de bitributação com cláusulas de matching credit recíprocas, como é o caso do Acordo Brasil-Índia e do Acordo Brasil-Coreia do Sul ${ }^{379}$.

Na década de 1990, somente três acordos de bitributação foram assinados pelo Brasil: com Holanda, em 1990, com China, em 1991 e com Finlândia, em 1996. Dentre estes três, os acordos com os países desenvolvidos Holanda e Finlândia contam com cláusulas de matching credit, o que indica que, apesar da reduzida atividade em matéria de negociação de acordos verificada nos anos 1990, a política brasileira manteve-se firme no sentido de exigir a concessão das mencionadas cláusulas.

No entanto, deve-se notar que tais cláusulas não constam dos acordos brasileiros celebrados após o ano de 2002, período em que as celebrações de acordos de bitributação voltaram a ser constantes, tendo como parceiros, de um modo geral, países que não são investidores tradicionais do Brasil, e com os quais o País não mantém, a priori, relacionamento regional ${ }^{380}$. É o caso de Ucrânia, Israel, México, África do Sul, Rússia, Venezuela e Peru, sendo que em nenhum dos acordos celebrados pelo Brasil com os referidos países existe cláusula de tax sparing ou matching credit.

\footnotetext{
${ }^{377}$ Cf. Luís Eduardo Schoueri, op. cit. (nota 75), pp. 274-275.

${ }^{378}$ Cf. Luís Eduardo Schoueri, op. cit. (nota 75), p. 276.

${ }^{379}$ Cf. Luís Eduardo Schoueri, op. cit. (nota 75), p. 276.

380 A exceção fica por conta do Decreto n 6.332/07, que promulgou a Convenção Adicional, alterando o Acordo Brasil-Bélgica, que será devidamente analisada adiante.
} 
Tal fato poderia, em princípio, ser entendido como um abandono, por parte do Brasil, da política firmemente adotada ao longo de anos, ou um sinal do caminho que será seguido nos novos acordos que vierem a ser celebrados futuramente.

Não obstante, parece-nos que uma conclusão desta natureza seria deveras precipitada, uma vez que, após o ano de 2002, o Brasil não celebrou novos acordos com os chamados "países desenvolvidos". Destarte, não se pode afirmar com segurança qual será o rumo adotado pelo País quando da celebração de novos acordos com países desenvolvidos.

No mesmo sentido, pontua Luís Eduardo Schoueri que o fato de novas cláusulas de tax sparing e matching credit não terem sido aprovadas nos acordos de bitributação brasileiros firmados a partir de 2002 não representa uma mudança de posicionamento do Brasil, mas simplesmente um possível sinal de que não havia motivos para que se acreditasse que o fluxo de rendimentos, nas relações com tais países, dar-se-ia em sentido único, tal como normalmente ocorre nos acordos entre países desenvolvidos e países em desenvolvimento $^{381}$.

De qualquer forma, certo é que os países desenvolvidos têm negado a inclusão de cláusulas de tax sparing e matching credit na celebração de acordos de bitributação com países em desenvolvimento, tal como foi exposto no capítulo anterior. Um bom indicativo da reticência dos países desenvolvidos a este respeito é a denúncia do Acordo BrasilAlemanha, de que se tratará adiante ${ }^{382}$.

Mencione-se, também, que o presente nível de desenvolvimento econômico do Brasil, bem como as alíquotas previstas atualmente na legislação interna brasileira, são motivos que podem influenciar os países desenvolvidos a não mais concordar com as cláusulas de tax sparing e matching credit.

De fato, à época em que os primeiros acordos brasileiros foram negociados, os dividendos, juros e royalties eram tributados na fonte à alíquota de $25 \%$, de modo que a redução na tributação na fonte a uma alíquota de $15 \%$, conforme previsto em boa parte dos acordos de bitributação brasileiros, poderia ser entendida como um incentivo fiscal ao investidor estrangeiro. Atualmente, como visto, os dividendos são isentos, e os juros e royalties remetidos ao exterior estão sujeitos a uma retenção na fonte de $15 \%$, tornando-se

\footnotetext{
${ }^{381}$ Cf. Luís Eduardo Schoueri, op. cit. (nota 75), p. 277.

${ }^{382}$ Cf. Luís Eduardo Schoueri, op. cit. (nota 75), p. 283.
} 
mais difícil a justificação das cláusulas de tax sparing e, sobretudo, das cláusulas de matching credit, sob tal perspectiva ${ }^{383}$.

A denúncia do Acordo Brasil-Alemanha também parece indicar que a postura do Brasil com relação às cláusulas de tax sparing e matching credit não se alterou, haja vista a recusa do Brasil em discutir a negociação de novo acordo sem o matching credit $^{384}$. Ademais, embora não se saiba ao certo qual será a posição do Brasil quando vier a assinar novo acordo de bitributação com um país desenvolvido, é certo que abrir mão do tax sparing e do matching credit poderá causar problemas, uma vez que os países que já concordaram com tais cláusulas poderiam vir a reivindicar igual tratamento, o que implicaria a revisão de grande parte da rede de acordos brasileiros ${ }^{385}$.

Ainda a respeito da política brasileira sobre a questão de que se trata, cumpre mencionar que o artigo 55 da Lei $n^{\circ} 10.637 / 02^{386}$ introduziu diretriz para que, nos tratados firmados pelo Brasil com demais países integrantes do Mercado Comum do Sul ("MERCOSUL"), seja incluída cláusula de tax sparing relativa a lucros e dividendos recebidos por pessoas jurídicas residentes do Brasil que não foram tributados em razão da vigência temporária de incentivo econômico, nacional, regional ou setorial do outro Estado contratante, sendo que a imposição deste tipo de cláusula fica limitada aos setores industrial e agrícola, de florestamento ou pesqueiro.

A despeito de tal previsão normativa, deve-se pontuar que não há cláusula de tax sparing nos acordo celebrados pelo Brasil com a Argentina e a Venezuela, únicos países do MERCOSUL com os quais o País possui acordo de bitributação atualmente.

\footnotetext{
${ }^{383}$ Cf. Luís Eduardo Schoueri, op. cit. (nota 75), p. 282.

${ }^{384}$ Cf. Luís Eduardo Schoueri, op. cit. (nota 75), p. 283.

385 Cf. Luís Eduardo Schoueri, op. cit. (nota 75), p. 282; Francisco Oswaldo Neves Dornelles, op. cit. (nota 323).

386 “Art. 55. Nas Convenções destinadas a evitar a dupla tributação da renda, a serem firmadas pelo Brasil com países integrantes do Mercado Comum do Sul (Mercosul), será incluída cláusula prevendo a concessão de crédito do imposto de renda sobre lucros e dividendos recebidos por pessoa jurídica domiciliada no Brasil que deveria ser pago no outro país signatário, mas que não haja sido em decorrência de lei de vigência temporária de incentivo ao desenvolvimento econômico, nacional, regional ou setorial.

Parágrafo único. O crédito referido no caput, observadas as demais condições gerais de concessão e outras que vierem a ser estabelecidas em legislação específica, somente será admitido quando os lucros ou dividendos distribuídos provenham, diretamente, de atividade desenvolvida no país estrangeiro signatário, relativa aos setores:

I - industrial, exceto da indústria de cigarro e bebidas em geral, inclusive os concentrados destas;

II - agrícola, de florestamento ou pesqueira."
} 
Feita esta breve análise do posicionamento brasileiro a respeito das cláusulas de tax sparing e matching credit, bem como de seu histórico, apresenta-se a seguinte tabela, que demonstra quais são os acordos de bitributação brasileiros que contêm (ou contiveram) os dispositivos em tela:

\begin{tabular}{|l|c|}
\hline \multicolumn{1}{|c|}{ Acordos Brasileiros } & Tipo de Cláusula \\
\hline Brasil-Alemanha ${ }^{387}$ & Matching credit \\
\hline Brasil-Áustria & Matching credit \\
\hline Brasil-Bélgica ${ }^{388}$ & Tax sparing / Matching credit \\
\hline Brasil-Canadá & Matching credit \\
\hline Brasil-Coreia do Sul & Matching credit \\
\hline Brasil-Dinamarca & Matching credit \\
\hline Brasil-Equador & Matching credit \\
\hline Brasil-Espanha & Matching credit \\
\hline Brasil-Filipinas & Matching credit \\
\hline Brasil-Finlândia & Matching credit \\
\hline Brasil-França & Matching credit \\
\hline Brasil-Holanda & Tax sparing / Matching credit \\
\hline Brasil-Hungria & Matching credit \\
\hline Brasil-Índia & Matching credit \\
\hline Brasil-Itália & Tax sparing / Matching credit \\
\hline Brasil-Japão & Matching credit \\
\hline Brasil-Luxemburgo & Matching credit \\
\hline Brasil-Noruega & Matching credit \\
\hline Brasil-República Eslovaca & Matching credit \\
\hline Brasil-República Tcheca & Matching credit \\
\hline Brasil-Suécia &
\end{tabular}

A partir da análise da tabela reproduzida, é possível notar que a tônica dominante nas negociações brasileiras de acordos de bitributação tem sido a adoção de cláusulas de matching credit, que prevalecem sobre as cláusulas de tax sparing. Como visto, o matching credit é de aplicação mais simples e menos burocrática do que o tax sparing, de tal sorte que se pode considerar louvável a presença de mais cláusulas deste primeiro tipo nos acordos brasileiros.

Percebe-se, também, que em praticamente todos os acordos brasileiros com países desenvolvidos há, ou pelo menos havia, cláusula de tax sparing e/ou matching credit. A

\footnotetext{
${ }^{387}$ Não está em vigor, pois foi denunciado pela Alemanha em 05 de abril de 2005.

388 As cláusulas previstas no Acordo Brasil-Bélgica expiraram recentemente, como se demonstrará mais adiante.
} 
exceção é a Bélgica, cujas cláusulas de tax sparing e matching credit recentemente expiraram, não sendo mais aplicáveis.

Desta feita, passa-se a descrever, em maiores detalhes, algumas das cláusulas de tax sparing e matching credit previstas nos acordos de bitributação celebrados pelo Brasil.

\subsection{Análise das cláusulas de tax sparing previstas nos acordos de bitributação celebrados pelo Brasil}

\subsubsection{Acordo Brasil-Japão}

Embora muito se debata sobre o tax sparing na realidade brasileira, o certo é que são raros os casos, como visto, em que estão previstas as cláusulas de tax sparing propriamente ditas, sendo muito mais comuns as cláusulas de matching credit.

A título de exemplo, cumpre mencionar inicialmente a cláusula de tax sparing prevista no Acordo Brasil-Japão ${ }^{389}$, mais especificamente em seu artigo 22(2)(b)(ii) ${ }^{390}$, tal como alterado pelo Decreto $\mathrm{n}^{\mathrm{o}} 81.194 / 78^{391}$.

De acordo com o dispositivo em comento, para fins de crédito a ser concedido pelo Japão, deve-se considerar o imposto brasileiro que teria sido pago na ausência de isenção ou redução do imposto, de acordo com medidas visando a promover o desenvolvimento econômico do Brasil.

\footnotetext{
${ }^{389}$ Acordo para Evitar a Dupla Tributação em Matéria de Impostos sobre Rendimentos, entre a República do Brasil e Japão, concluído em Tóquio, a 24 de janeiro de 1967. Aprovado pelo Decreto Legislativo nº $43 / 67$ e promulgado pelo Decreto ${ }^{\circ}$ 61.899/67.

(ii) Para fins do crédito referido no sub-parágrafo (a) acima, o imposto brasileiro deverá incluir o montante do imposto brasileiro que deveria ter sido pago se não houvesse a isenção ou redução do imposto brasileiro de acordo com as medidas especiais de incentivo visando a promover o desenvolvimento econômico do Brasil, vigentes em 23 de março de 1976, ou que possam ser introduzidas posteriormente na legislação tributária brasileira, modificando ou ampliando as medidas existentes, desde que a extensão do benefício concedido ao contribuinte por tais medidas seja acordado pelos Governos de ambos os Estados Contratantes."

${ }^{391}$ Protocolo que Modifica e Complementa a Convenção entre os Estados Unidos do Brasil, atualmente República Federativa do Brasil, e o Japão, Destinada a Evitar a Dupla Tributação em Matéria de Impostos sobre Rendimentos.
} 
Trata-se de cláusula de tax sparing específica, na medida em que se faz referência às medidas de incentivo destinadas a promover o desenvolvimento econômico do Brasil vigentes em 23 de março de 1976. Ademais, a extensão do tax sparing a outros incentivos que viessem a ser introduzidos na legislação brasileira estava condicionada ao entendimento mútuo entre os dois Estados contratantes.

Ademais, em troca de notas realizada entre os dois Estados contratantes em 23 de março de 1976, tratou-se de listar, com pormenores, quais eram os incentivos fiscais destinados a promover o desenvolvimento econômico do Brasil vigentes naquela data, apontado-se os dispositivos da legislação interna brasileira em que tais incentivos estavam previstos.

\subsubsection{Acordo Brasil-Bélgica}

Em sua redação original, o artigo $23^{392}$ do Acordo Brasil-Bélgica ${ }^{393}$ previa, além do matching credit para juros, dividendos e royalties, a aplicação de espécie de tax sparing

392 “ARTIGO 23

Regras gerais de tributação

(...)

2. No caso da Bélgica, a dupla tributação será evitada da seguinte forma:

I - quando um residente da Bélgica receber rendimentos não indicados nos incisos II, III e IV deste parágrafo, que forem tributáveis no Brasil em conformidade com as disposições da presente Convenção, a Bélgica isentará esses rendimentos de imposto, mas poderá, para calcular o montante de seus impostos sobre o restante dos rendimentos desse residente, aplicar a mesma taxa que aplicaria se esses rendimentos não tivessem sido isentos;

II - a) no que concerne aos dividendos tributáveis em conformidade com o Artigo 10, parágrafo 2, e não indicados no inciso III abaixo, os juros tributáveis em conformidade com o Artigo 11, parágrafo 2, 3-b ou 8, e os "royalties" tributáveis em conformidade com o Artigo 12, parágrafo 2 ou 6, a Bélgica concederá, sobre o imposto belga devido pelo referido residente, uma dedução igual a $20 \%$ do montante bruto dos rendimentos acima mencionados que compuserem a base tributável em nome desse residente;

b) na eventualidade de o Brasil reduzir a carga fiscal normal aplicável aos rendimentos acima mencionados atribuídos a não-residentes, a uma alíquota inferior a 14\% do montante bruto tais rendimentos, a Bélgica reduziria de 20 para $15 \%$ a alíquota dessa dedução. No caso de o Brasil eliminar a mencionada carga fiscal, a Bélgica limitará em 5\% a alíquota da dedução;

c) não obstante as disposições de sua legislação, a Bélgica concederá igualmente a dedução de $20 \%$ prevista na alínea "a" acima, em relação aos rendimentos acima mencionados que são tributáveis no Brasil em virtude da Convenção e das disposições gerais da legislação brasileira, quando eles aí estiverem temporariamente isentos de imposto pelas disposições legais especiais destinadas a favorecer os investimentos necessários ao desenvolvimento da economia do Brasil. As autoridades competentes dos Estados Contratantes determinarão de comum acordo os rendimentos que se beneficiarão desta disposição."

393 Acordo para Evitar a Dupla Tributação e Regular Outras Questões em Matéria de Impostos sobre a Renda entre o Governo da República Federativa do Brasil e o Governo do Reino da Bélgica, concluído em Brasília, a 23 de julho de 1972. Aprovado pelo Decreto Legislativo $n^{\circ} 76 / 72$ e promulgado pelo Decreto $n^{\circ} 72.542 / 73$. 
para os referidos rendimentos, quando estivessem temporariamente isentos de imposto no Brasil, em virtude de disposições legais especiais destinadas a favorecer os investimentos necessários ao desenvolvimento da economia do País. Diz-se que se tratava de espécie de tax sparing, embora no próprio Acordo Brasil-Bélgica previa-se que, nessas situações, o imposto brasileiro seria considerado como tendo sido pago a uma alíquota de $20 \%$.

Trata-se, portanto, de uma prefixação do montante do crédito no texto do acordo, nos moldes do que ocorre com o matching credit. Não se trata, contudo, de cláusula de matching credit, na medida em que se toma por referência a existência de legislação de incentivos fiscais destinados a promover o desenvolvimento econômico do Brasil.

De qualquer forma, importa notar que tal cláusula foi inteiramente suprimida e substituída por outra ${ }^{394}$, nos termos do disposto no Decreto ${ }^{\circ}$ 6.332/07, que promulgou no Brasil o Acordo Adicional que alterava o Acordo Brasil-Bélgica.

Nos termos da nova redação dada ao artigo 23 do Acordo Brasil-Bélgica, os juros, dividendos e royalties pagos em razão de investimentos diretamente ligados a projetos de desenvolvimento industrial, comercial, turístico ou agrícola no Brasil carregariam um crédito de imposto, a ser compensado na Bélgica, equivalente à alíquota do imposto brasileiro efetivamente aplicada, acrescida de 5\%. Tal disposição também se aplicava nas hipóteses em que o Brasil renunciasse ao direito de tributar os rendimentos em tela, nos termos de sua legislação interna.

394 “2.No caso da Bélgica, a dupla tributação será evitada da seguinte forma:

a) Quando um residente da Bélgica receber rendimentos tributáveis no Brasil em conformidade com as disposições da presente Convenção, com exceção daquelas contidas nos artigos 10, parágrafos 2 e 6, 11 , parágrafos 2, 3, b) e 8, e 12, parágrafos 2 e 6, a Bélgica isentará esses rendimentos do imposto, mas poderá, para calcular o montante de seus impostos sobre o restante dos rendimentos desse residente, aplicar a mesma alíquota que aplicaria se esses rendimentos não tivessem sido isentos;

b) Ressalvadas as disposições da legislação belga relativas à imputação sobre o imposto belga de impostos pagos no estrangeiro, quando um residente da Bélgica receber rendimentos que estejam compreendidos em seu rendimento global sujeito ao imposto belga e que consistam em dividendos tributáveis em conformidade com o artigo 10, parágrafos 2 ou 6, e não isentos do imposto belga em virtude do c) adiante, em juros tributáveis em conformidade com o artigo 11, parágrafos 2,3 , b) ou 8 , ou em "royalties" tributáveis em conformidade com o artigo 12, parágrafos 2 ou 6 , o imposto brasileiro pago sobre tais rendimentos será imputado sobre o imposto belga correspondente aos referidos rendimentos.

Todavia, no que concerne aos referidos rendimentos que se beneficiam de uma imputação na Bélgica em conformidade com a alínea precedente e que são pagos em razão de investimentos que estejam diretamente ligados a projetos de desenvolvimento industrial, comercial, turístico ou agrícola no Brasil, essa imputação será calculada como se o imposto brasileiro tivesse sido pago a uma alíquota de $5 \%$ mais elevada que a alíquota efetivamente aplicada. Esta disposição aplicar-se-á igualmente quando o Brasil renunciar, em virtude de sua legislação interna, a tributar os rendimentos em questão. A imputação cessará de ser calculada como se o imposto brasileiro tivesse sido pago a uma alíquota de $5 \%$ mais elevada no que concerne aos impostos belgas devidos sobre rendimentos de períodos tributáveis que comecem a partir de $1^{\circ}$ de janeiro de 2012 . A presente alínea não será aplicável aos "royalties" indicados no artigo 12, parágrafo 2, b)." 
Deve-se notar que o tax sparing assim estabelecido não é mais aplicável, na medida em que o texto do acordo previa que o crédito superior, em $5 \%$, ao montante do imposto cobrado no Brasil, deixaria de ser considerado, para fins da apuração do imposto belga, a partir de $1^{\mathrm{o}}$ de janeiro de 2012.

Desta forma, pode-se notar que, em relação à Bélgica, estabeleceu-se, no ano de 2007, uma sunset clause, nos exatos termos das melhores práticas recomendadas pela OCDE. Com isso, a Bélgica passa a ser um dos raros exemplos (se não o único) de país desenvolvido com o qual o Brasil possui acordo de bitributação, mas não possui cláusula de tax sparing ou matching credit.

Pode-se presumir que a alteração do texto original do artigo 23 partiu de iniciativa da Bélgica, e não do Brasil. É de se questionar se esse não seria um indicativo de que os países desenvolvidos que estão revendo suas práticas em relação ao tax sparing e ao matching credit estão começando a conseguir impor algumas de suas resoluções sobre a firme política brasileira relativa a tais cláusulas.

\subsection{Análise das cláusulas unilaterais de matching credit previstas nos acordos de bitributação celebrados pelo Brasil}

Sendo o matching credit mecanismo mais comum do que o tax sparing na seara dos acordos de bitributação brasileiros, cumpre tecer comentários sobre algumas das cláusulas previstas nos acordos firmados pelo Brasil.

Em um primeiro momento, analisar-se-ão cláusulas unilaterais, nas quais se considera, para fins de aplicação do crédito no outro Estado contratante, que o imposto brasileiro foi pago a uma alíquota fixa predeterminada no texto do próprio acordo.

Posteriormente, serão analisadas algumas cláusulas de matching credit mútuas ou recíprocas, nas quais o crédito fixo previsto em acordo aplica-se, indistintamente, nas duas direções dos fluxos de rendimentos (Brasil para o outro Estado contratante; outro Estado contratante para o Brasil). 


\subsubsection{Acordo Brasil-Alemanha}

O Acordo Brasil-Alemanha ${ }^{395}$, promulgado em 1976, foi denunciado pela Alemanha em 05 de abril de 2005, quase 30 anos depois de sua assinatura, de tal sorte que tal instrumento teve sua vigência encerrada em $1^{\text {o }}$ de janeiro de $2006^{396}$.

Nos termos do artigo 24 do Acordo Brasil-Alemanha ${ }^{397}$, previa-se a isenção, na Alemanha, para os dividendos pagos por empresa brasileira a empresa alemã que detivesse diretamente, no mínimo, $25 \%$ do capital da empresa brasileira.

Para as demais hipóteses de fluxos de dividendos, juros e royalties do Brasil para residentes na Alemanha, havia a previsão de matching credit para fins de eliminação da bitributação. Desta feita, ao se computar o crédito a ser descontado do imposto devido na

395 Acordo para Evitar a Dupla Tributação em Matéria de Impostos sobre a Renda e o Capital, entre o Brasil e a República Federal da Alemanha, concluído em Bonn, a 27 de junho de 1975. Aprovado pelo Decreto Legislativo $n^{\circ}$ 92/75 e promulgado pelo Decreto $n^{\circ} 76.988 / 76$.

${ }^{396}$ Em virtude da denúncia promovida pela Alemanha, editou-se o Decreto $\mathrm{n}^{\circ}$ 5.654/95, que revogou o Decreto $\mathrm{n}^{\circ} 76.988 / 76$, a partir de $1^{\circ}$ de janeiro de 2006. Ver também o Ato Declaratório Executivo SRF $\mathrm{n}^{\circ}$ 72/05, que dispõe sobre a data do término de vigência do Acordo Brasil-Alemanha.

397 “ARTIGO 24 - Método para Eliminar a Dupla Tributação

1. No caso de um residente da República Federal da Alemanha, serão excluídos da base de cálculo sobre a qual incide o imposto alemão os seguintes rendimentos:

a) rendimentos de bens imobiliários que façam parte do ativo de um estabelecimento permanente situado no Brasil e ganhos obtidos através da alienação de tais bens;

b) lucros de uma empresa e ganhos aos quais se aplicam o artigo $7^{\circ}$ e o parágrafo $2^{\circ}$ do artigo 13 ;

c) dividendos mencionados no artigo 10, pagos a uma empresa residente da República Federal da Alemanha por uma empresa residente do Brasil se, no mínimo, $25 \%$ do capital da empresa brasileira pertencer diretamente à empresa alemã;

d) remunerações às quais se aplicam o artigo 15 e os parágrafos $1^{\circ}$ e $3^{\circ}$ do artigo 18 ;

e) lucros aos quais se aplica o parágrafo $6^{\circ}$ do artigo 10 .

A República Federal da Alemanha conservará, no entanto, o direito de levar em conta na determinação de suas alíquotas de imposto os rendimentos assim excluídos.

As disposições precedentes aplicar-se-ão igualmente a todo o capital situado no Brasil, se os rendimentos desse capital forem ou puderem vir a ser excluídos da base de cálculo, sobre a qual incide o imposto alemão. (...)

3. Para os fins da concessão do crédito mencionado no parágrafo 2, o imposto brasileiro será considerado como sendo:

a) de $25 \%$ no caso dos dividendos, definidos no parágrafo 5 do artigo 10, pagos a um residente da República Federal da Alemanha que possua no mínimo 10\% do capital com direito a voto da sociedade brasileira; e de $20 \%$ em todos os demais casos;

b) de $20 \%$ no caso dos juros, definidos no parágrafo 4 do artigo 11 ;

c) de $25 \%$ no caso dos royalties, indicados no parágrafo 2 , b, do artigo 12 , se forem pagos a um residente da República Federal da Alemanha que possua direta ou indiretamente no mínimo 50\% do capital com direito a voto da sociedade brasileira, desde que não sejam dedutíveis da determinação do rendimento tributável da sociedade que paga os royalties; e de $20 \%$ em todos os demais casos. (...)” 
Alemanha sobre os referidos rendimentos, considerava-se que o imposto brasileiro havia sido pago de acordo com as alíquotas mencionadas na seguinte tabela:

\begin{tabular}{|c|c|}
\hline & Matching credit no Acordo Brasil-Alemanha \\
\hline \multirow[t]{2}{*}{ Dividendos } & $\begin{array}{l}25 \% \text { no caso dos dividendos pagos a um residente da Alemanha } \\
\text { que possuísse no mínimo } 10 \% \text { do capital com direito a voto da } \\
\text { sociedade brasileira }\end{array}$ \\
\hline & $20 \%$ em todos os demais casos \\
\hline Juros & $20 \%$ \\
\hline \multirow[t]{2}{*}{ Royalties } & $\begin{array}{l}25 \% \text { no caso dos royalties, que não os provenientes do uso ou da } \\
\text { concessão do uso de marcas de indústria ou comércio, pagos a um } \\
\text { residente da Alemanha que possuísse, direta ou indiretamente, no } \\
\text { mínimo } 50 \% \text { do capital com direito a voto da sociedade brasileira, } \\
\text { desde que estes não fossem dedutíveis da determinação do } \\
\text { rendimento tributável da sociedade que paga os royalties }\end{array}$ \\
\hline & $20 \%$ em todos os demais casos \\
\hline
\end{tabular}

Deve-se mencionar, nesse sentido, que o matching credit certamente foi um dos motivos cruciais para a denúncia do Acordo Brasil-Alemanha, ao lado de outros como a interpretação brasileira acerca da qualificação dos serviços técnicos e de assistência técnica e dos prêmios de resseguro, bem como divergências entre a legislação brasileira de preços de transferência e o princípio arm's length expresso no artigo $9^{\circ}$ do mencionado acordo ${ }^{399}$.

Assim, embora seja notório que não foi o matching credit o único motivo que levou a Alemanha, após tentativas de renegociação, a denunciar o acordo de bitributação celebrado com o Brasil, sabe-se que tal fator foi fortemente considerado, por ter a Alemanha entendido que, em vista do estágio de desenvolvimento da economia brasileira, não se justificava mais a concessão de cláusulas dessa natureza ${ }^{400}$.

\footnotetext{
${ }^{398}$ Conforme relata Joseph C. Amico, o matching credit mais elevado para participações substanciais de residentes na Alemanha em empresas brasileiras provavelmente deve-se ao fato de que, até 1977, tal país ainda não havia implementado o crédito indireto para empresas. $\mathrm{O}$ autor aponta que a alteração na legislação interna alemã não fez com que o Acordo Brasil-Alemanha fosse alterado. Cf. Joseph A. Amico. "Brazil: Developing and implementing tax treaty policy: the tax sparing clause". Bulletin for International Taxation. agosto/setembro, 1989, p. 410.

${ }^{399}$ A respeito dos motivos que levaram a Alemanha a denunciar o acordo de bitributação celebrado com o Brasil, cf. Gerd Willi Rothmann, op. cit. (nota 336), pp. 146-179; Wolfgang Oepen. "A Alemanha denuncia seu tratado de dupla tributação com o Brasil - razões e consequiências da denúncia do tratado sob um ponto de vista alemão". Revista de Direito Tributário Internacional. v. 1. São Paulo: Quartier Latin, 2005, pp. 209226.

${ }^{400}$ Cf. Gerd Willi Rothmann, op. cit. (nota 336), p. 147.
} 
Com efeito, a Alemanha tem abandonado sua antiga política de adotar cláusulas de tax sparing e matching credit em seus acordos de bitributação ${ }^{401}$, sobretudo no que diz respeito a países que, em seu entender, não mais podem ser considerados países em desenvolvimento ${ }^{402}$.

\subsubsection{Acordo Brasil-Áustria}

Também no Acordo Brasil-Áustria é possível encontrar cláusula de matching credit $^{403}$. Com efeito, o artigo $23^{404}$, parágrafo $5^{\circ}$, do Acordo Brasil-Áustria dispõe sobre o matching credit de $25 \%$ do montante bruto do rendimento aplicável aos dividendos, juros e royalties recebidos, do Brasil, por residentes na Áustria.

O matching credit não se aplica aos dividendos pagos por sociedade brasileira de que participe sociedade residente na Áustria em, no mínimo, 25\%, haja vista que em tal situação há previsão específica, no parágrafo $6^{\circ}$ do artigo 23 do Acordo Brasil-Áustria, de isenção na Áustria sobre tais dividendos.

O mesmo comentário pode ser feito com relação aos royalties: serão isentos na Áustria, nos termos do parágrafo $7^{\circ}$ do artigo 23 do Acordo Brasil-Áustria, os royalties

${ }^{401}$ Com efeito, o tax sparing e o matching credit eram entendidos como práticas consagradas pela Alemanha na negociação de seus acordos de bitributação. Cf. Roberto França de Vasconcellos, op. cit. (nota 22), p. 168.

${ }^{402}$ Cf. Gerd Willi Rothmann, op. cit. (nota 336), pp. 177-178.

403 Acordo para Evitar a Dupla Tributação em Matéria de Impostos sobre a Renda e o Capital, entre a República Federativa do Brasil e a República da Áustria, concluído em Viena, a 24 de maio de 1975. Aprovado pelo Decreto Legislativo no 95/75 e promulgado pelo Decreto $n^{\circ} 78.107 / 76$.

404 “ARTIGO 23 - Método para eliminar a dupla tributação

(...)

4. Com ressalva das disposições do Artigo 11 parágrafo 3.b, quando um residente da Áustria receber rendimento que, de acordo com as disposições dos Artigos 10, 11, 12 e 13 parágrafo 3, sejam tributáveis no Brasil, a Áustria permitirá que do imposto que recair sobre os rendimentos dessa pessoa seja deduzido um montante igual ao imposto pago no Brasil.

Todavia, o montante deduzido não poderá exceder à fração do imposto, calculado antes da dedução correspondente aos rendimentos recebidos do Brasil.

5. Na aplicação do parágrafo 4 o imposto pago sobre dividendos, juros e "royalties" recebidos do Brasil será considerado como tendo sido pago à alíquota de $25 \%$ do montante bruto do rendimento.

6. Os dividendos pagos por uma sociedade residente do Brasil a uma sociedade residente da Áustria que possua no mínimo $25 \%$ das ações do capital da sociedade que paga os dividendos serão isentos do imposto de sociedade e do imposto incidente sobre empresas industriais e comerciais na Áustria.

7. Enquanto os "royalties" que forem pagos por uma sociedade residente do Brasil a uma sociedade residente da Áustria que possua mais de $50 \%$ do capital votante da sociedade que paga os "royalties" não forem dedutíveis para fins tributários no Brasil, esses "royalties" serão isentos de imposto na Áustria.

(...)" 
pagos por sociedade residente no Brasil a uma sociedade residente da Áustria que possua mais de $50 \%$ do capital votante da sociedade brasileira, enquanto os referidos royalties não forem dedutíveis para fins tributários no Brasil.

Nas duas hipóteses referidas, como o método utilizado para eliminar a bitributação é o da isenção, e não o do crédito, não há que se falar em aplicação do mecanismo do matching credit.

\subsubsection{Acordo Brasil-França}

No que diz respeito à análise da cláusula de matching credit do Acordo BrasilFrança $^{405}$, cumpre fazê-la mediante a exposição de caso que se tornou famoso por discutir os mecanismos de concessão de crédito do imposto no referido acordo: o caso Natexis, de 26 de julho de 2006, julgado pelo Conseil d'État francês ${ }^{406}$.

O Banco Natexis, residente na França, possuía determinados investimentos no Brasil, de modo que recebia juros que tinham sua fonte localizada no País. No momento do cálculo do imposto a ser pago na França, Estado da residência, buscou o reconhecimento de um crédito de imposto relativo à cláusula constante do artigo XXII(2)(d) do Acordo Brasil-França $^{407}$, pela qual se considera, no que diz respeito aos juros (artigo XI), que o imposto brasileiro tenha sido cobrado à alíquota de $20 \%$.

\footnotetext{
405 Acordo para Evitar a Dupla Tributação e Prevenir a Evasão Fiscal em Matéria de Impostos sobre o Rendimento, celebrado entre o Brasil e a França, em Brasília, em 10 de setembro de 1971. Aprovado pelo Decreto Legislativo $\mathrm{n}^{\circ} 87 / 71$ e promulgado pelo Decreto $\mathrm{n}^{\circ} 70.506 / 72$.

${ }^{406}$ Sobre o assunto, cf. Natalie Matos Silva. "O caso Société Natexis Banque Populaire e a cláusula de matching credit do Acordo de Bitributação entre Brasil e França". OLIVEIRA, Ricardo Mariz de; SCHOUERI, Luís Eduardo; ZILVETI, Fernando Aurelio. Revista Direito Tributário Atual. v. 28. São Paulo: Instituto Brasileiro de Direito Tributário: Dialética, 2012, pp. 231-248.

407 "ARTIGO XXII

Regras gerais de tributação

A dupla tributação será evitada da seguinte forma:

(...)

2. no caso da França:

(...)

c) no que concerne aos rendimentos indicados nos Artigos X, XI, XII, XIII, XIV, XVI e XVII sobre os quais tenha incidido o imposto brasileiro em conformidade com as disposições de tais artigos, a França concederá aos seus residentes que recebem tais rendimentos de fonte brasileira um crédito tributário correspondente ao imposto pago no Brasil, no limite do imposto francês referente a esses mesmos rendimentos;

d) no que concerne aos rendimentos indicados nos Artigos X, XI e parágrafo 2 "c", do Artigo XII, o imposto brasileiro é considerado como tendo sido cobrado à taxa mínima de $20 \%$;
} 
Com efeito, nos termos do artigo XI do Acordo Brasil-França ${ }^{408}$, que dispõe acerca da repartição de competências tributárias entre os Estados contratantes relativamente aos juros, como regra geral os juros podem ser tributados no Estado da residência do investidor e no Estado da fonte, sendo que neste último caso o imposto não poderá ser superior a $15 \%$ do montante bruto dos referidos juros.

Mencione-se, ainda, que o artigo XI(3)(b) determina que, no que se refere aos juros dos empréstimos e créditos concedidos, por um período mínimo de sete anos pelos estabelecimentos bancários com participação de um organismo público de financiamento especializado e ligados à venda de bens de equipamento ou ao estudo, à instalação ou ao fornecimento de complexos industriais ou científicos e de obras públicas, o imposto cobrado pelo Estado da fonte não poderá exceder a alíquota de $10 \%$.

É exatamente essa a situação em que se enquadrava o Banco Natexis: os juros provenientes do Brasil recebidos por esta instituição financeira estavam, em princípio, sujeitos a uma alíquota de $10 \%$ na fonte. No entanto, em virtude de um benefício fiscal previsto na legislação brasileira, a alíquota relativa à tributação na fonte, no Brasil, foi reduzida a $0 \%$, não havendo que se falar em qualquer tributação no Brasil sobre tais rendimentos.

Justamente em razão do benefício fiscal concedido pelo Brasil e pelo fato de os juros não terem sofrido tributação alguma na fonte, o Fisco francês negou ao Banco Natexis o direito de aproveitamento do crédito de $20 \%$ previsto no artigo $\mathrm{XXII(2)(d)} \mathrm{do}$ Acordo Brasil-França.

É importante notar, nesse ponto, que em 08 de dezembro de 1972, as autoridades fiscais francesas editaram instrução (Instrução 14 B-17-72) que esclarecia a natureza e a

(...)"

408 "ARTIGO XI - Juros

1. Os juros provenientes de um Estado Contratante e pagos a um residente de outro Estado Contratante são tributáveis nesse outro Estado.

2. No entanto, esses juros podem ser tributados no Estado Contratante de que provêm e em conformidade com a legislação deste Estado, mas o imposto assim estabelecido não poderá exceder a 15\% do montante bruto.

3. Não obstante as disposições do parágrafo 2:

a) os juros dos empréstimos e créditos concedidos pelo governo de um Estado Contratante não serão tributados no Estado de que provêm;

b) a taxa de imposto não pode exercer a $10 \%$ no que se refere aos juros dos empréstimos e créditos concedidos, por um período mínimo de sete anos pelos estabelecimentos bancários com participação de um organismo público de financiamento especializado e ligados à venda de bens de equipamento ou ao estudo, à instalação ou ao fornecimento de complexos industriais ou científicos assim como de obras públicas. (...)" 
forma de aplicação do mecanismo de crédito de imposto previsto no Acordo Brasil-França, em seu artigo XXII, parágrafo $2^{\circ}$, alíneas "c" e "d".

Nos termos da referida instrução, para fins de cálculo do imposto devido na França, devia-se, em qualquer situação, considerar o crédito equivalente a $20 \%$ do montante bruto de tais rendimentos, ainda que na ausência de qualquer imposição fiscal brasileira sobre os juros em comento ${ }^{409}$.

Houve, portanto, mais ou menos à mesma época em que entrou em vigor o Acordo Brasil-França (1971), o reconhecimento pelas autoridades fiscais francesas de que os residentes na França possuíam um direito incondicional ao crédito de imposto previsto no artigo XXII(2)(d), ainda que diante de uma total ausência de tributação na fonte, no Brasil.

Com notável astúcia, Guy Gest ${ }^{410}$ afirma que, dada a diferença de apenas 14 meses entre a assinatura do Acordo Brasil-França e a edição da Instrução 14 B-17-72, pode-se legitimamente supor que os responsáveis pela elaboração desta última estavam familiarizados com o texto do primeiro, já que tanto um quanto o outro instrumento são oriundos de um mesmo órgão governamental.

Ademais, três meses após a assinatura do Acordo Brasil-França (e doze meses antes da publicação da Instrução 14 B-17-72), foi divulgado o relatório geral da Comissão de Assuntos Estrangeiros da Assembleia Nacional francesa a respeito do projeto de lei que autorizava a ratificação do referido tratado internacional. No relatório em tela, o Deputado Trémeau, seu autor, expunha claramente que os juros exonerados ou tributados a uma alíquota reduzida no Brasil faziam jus a um crédito de imposto igual a $20 \%$ de seu montante bruto ${ }^{411}$.

Assim, conclui Guy Guest ser possível crer que a Instrução 14 B-17-72 estava não somente conforme o texto do Acordo Brasil-França, como também era fiel à intenção de seus autores ${ }^{412}$.

\footnotetext{
409 «Conformément aux dispositions de l'article 22, paragrafe 2, $c$ et $d$ de la convention, les intérêts de tout nature ouvrent droit, pour le calcul de l'impôt français dans les bases daquel ils sont compris (impôt sur le revenu, impôt sur les sociétés) et en toutes hypothèses c'est-à-dire même en l'absence de tout prélèvement fiscal brésilien, à un crédit équivalent à $20 \%$ du montant brut des produits. »

${ }^{410}$ Cf. Guy Guest, op. cit. (nota 105), p. 2.125.

${ }^{411}$ Cf. Guy Guest, op. cit. (nota 105), p. 2.125.

${ }^{412}$ Cf. Guy Guest, op. cit. (nota 105), p. 2.125.
} 
Em 1997, em sentido contrário ao anteriormente firmado, as autoridades fiscais francesas voltaram a manifestar-se a respeito do Acordo Brasil-França, por meio de nova instrução (Instrução 14 A-7-97). Passados 25 anos da edição da primeira instrução, em 05 de dezembro de 1997, decidiu-se que somente poderia ser reconhecido o direito ao crédito na França na hipótese de algum imposto ter sido pago no Brasil com relação aos juros considerados $^{413}$. Entendeu-se, assim, que o artigo XXII(2)(d) deveria ser interpretado de modo a subordinar o reconhecimento do crédito da França à ocorrência de tributação no Brasil, em total dissonância com a instrução emanada em 1972.

Considerando-se a mudança de posicionamento do Fisco francês a respeito da interpretação a ser conferida à cláusula de crédito de imposto prevista no Acordo BrasilFrança, requereu o Banco Natexis ao Conseil d'État: (i) a anulação do parágrafo II da Instrução 14 A-7-97, relativo às modalidades de imputação do crédito de imposto no que concerne aos juros de fonte brasileira, e (ii) subsidiariamente, a anulação da decisão de 25 de julho de 2005, que havia rejeitado sua demanda pelo afastamento do parágrafo II da referida instrução.

Desta forma, coube ao Conseil d'État, na decisão em comento, determinar qual das duas instruções editadas pelas autoridades fiscais francesas interpretava corretamente o artigo XXII(2)(d) do Acordo Brasil-França.

O Conseil d'État entendeu, nos termos da Instrução 14 A-7-97, que o crédito de $20 \%$ somente poderia ser concedido caso tivesse havido algum imposto efetivamente recolhido no Brasil, o que não era o caso.

A referida decisão, baseada nas conclusões de Pierre Collin, Comissaire $d u$ Gouvernement, assentou-se sobre a premissa de que, veiculando o artigo XXII(2)(d) notadamente uma cláusula de matching credit, a sua aplicação requeria, necessariamente, que tivesse havido tributação sobre os rendimentos (no caso, juros) no Brasil.

Assim, a Instrução 14 B-17-72 teria, erroneamente, interpretado a cláusula prevista no artigo XXII(2)(d) como sendo de tax sparing, situação em que o crédito seria concedido pelo Estado da residência ainda que na ausência de qualquer tributação no Brasil. Tal "erro" teria sido corrigido com a edição da Instrução 14 A-7-97, ao esclarecer que se trata

413 «Cette mesure est rapportée el il est précisé qu'aucun crédit d'impôt ne peut etrê imputé sur l'impôt français lorsque aucun impôt n'a eté acquitté au Brésil à raison de ces revenus. » 
o artigo XXII(2)(d) de uma cláusula de matching credit, de modo que restaria vedada a concessão do crédito na hipótese de exoneração do tributo pelo Estado da fonte ${ }^{414}$.

Invocando a necessidade de se interpretar literalmente as disposições do Acordo Brasil-França, o que decorreria do princípio da interpretação estrita que guiaria a interpretação da lei fiscal e das convenções internacionais, Pierre Collin buscou associar as alíneas "c" e "d" do parágrafo $2^{\circ}$ do artigo XXII, para afirmar que o crédito de imposto fictício previsto na alínea "d" decorre, inevitavelmente, do crédito de imposto clássico previsto na alínea "c".

Desta feita, a alínea "c" do artigo XXII enuncia o crédito do imposto efetivo, partindo-se deste para o caso particular da alínea "d", que trata do matching credit.

Assim, não poderia um contribuinte beneficiar-se do crédito previsto na alínea "d" ("no que concerne aos rendimentos indicados nos artigos X, XI e parágrafo 2 "c", do artigo XII, o imposto brasileiro é considerado como tendo sido cobrado à taxa mínima de 20\%”) se não houver direito, ao menos em princípio, a um crédito do imposto efetivo, nos termos da alínea "c", que corresponde ao imposto que tenha incidido e sido pago no Brasil. Não havendo imposto incidido e pago e, consequentemente, direito ao crédito do imposto efetivo, não haveria que se falar em matching credit.

Em nosso entender, à luz dos conceitos de matching credit e tax sparing, não se pode concordar com o entendimento manifestado pelo Conseil d'État ao julgar o caso do Banco Natexis.

Considerando-se o quanto exposto em tópico anterior a respeito da natureza das cláusulas de matching credit e tax sparing, pode-se concluir que o artigo XXII(2)(d) do Acordo Brasil-França contém legítima cláusula de matching credit, que poderá ser aplicada ainda que na ausência de qualquer tributação no Brasil (Estado da fonte) - justamente porque, no matching credit, a tributação (ou ausência dela) no Estado da fonte é absolutamente irrelevante

Ademais, para fazer valer a decisão que foi proferida no caso do Banco Natexis, o Conseil d'État e o Comissaire du Governement interpretaram literalmente o Acordo Brasil-

${ }^{414}$ Cf. Anapaula Trindade Marinho e Vanessa Arruda Ferreira, op. cit. (nota 61), pp. 57-58. 
França, chegando à conclusão de que o artigo XXII era inaplicável ao caso concreto pela inexistência de dupla tributação.

De acordo com o entendimento ali manifestado, somente se houvesse disposição específica abrangendo os casos de dupla não tributação, como é efetivamente a situação do Banco Natexis, haveria que se falar na aplicação do artigo XXII (destinado exclusivamente aos casos de dupla tributação).

No entanto, a simples interpretação literal do artigo XXII(2)(d), a despeito do ponto de vista defendido por Pierre Collin, poderá conduzir o intérprete ao reconhecimento de que o matching credit deverá ser concedido ainda que não haja qualquer tributação no Brasil, justamente porque não existe, no texto do Acordo Brasil-França, qualquer disposição excepcionando a aplicação de tal crédito em casos como o do Banco Natexis.

Ademais, deve-se ter em conta que o texto do Acordo Brasil-França, como qualquer tratado internacional, deverá ser interpretado, nos termos do artigo 31 da Convenção de Viena, "em seu contexto e à luz de seu objetivo e finalidade".

Desta feita, entendendo-se o contexto nos termos dos itens 2 e 3 do artigo 31 da Convenção de Viena, impende que sejam mencionados novamente a Instrução 14 B-17-72 e o relatório geral da Comissão de Assuntos Estrangeiros da Assembleia Nacional francês, de autoria do Deputado Trémeau, documentos contemporâneos à assinatura do Acordo Brasil-França e que claramente determinavam que o direito ao matching credit subsistia ainda que diante de uma hipótese de exoneração total dos juros no Brasil, Estado da fonte.

Desta forma, pelo dito contexto, é possível chegar à conclusão de que os negociadores do Acordo Brasil-França pretendiam, à época de sua assinatura e ratificação, que o matching credit fosse concedido a residentes franceses que investissem no Brasil, independentemente de ter havido qualquer tributação brasileira sobre os juros auferidos.

Nada obstante, a verificação do objetivo e da finalidade das cláusulas de tax sparing e matching credit no contexto da disciplina dos acordos de bitributação também é relevante para o deslinde da questão.

Portanto, não pode ser aceito o entendimento adotado pelo Conseil d'État, segundo o qual o matching credit somente pode ser concedido quando se está diante de alguma tributação (e, por consequência, de algum crédito do imposto efetivo, nos termos do artigo 
XXII(2)(c)), na medida em que tal argumentação desconsidera, por completo, que o objetivo das cláusulas de matching credit não é o de evitar a dupla tributação (ou dupla não tributação) internacional.

Por fim, Guy Guest demonstra o absurdo da interpretação do Conseil d'État na decisão do caso do Banco Natexis: de acordo com a cláusula de matching credit prevista no artigo $\mathrm{XXII}(2)(\mathrm{d})$, caso o Brasil tribute os juros na fonte à alíquota de $15 \%$, o crédito de imposto na França será de 20\%; na hipótese de a alíquota brasileira ser reduzida a 5\%, os mesmos 20\% de crédito serão concedidos pela França; por fim, ainda que o Brasil diminua sua alíquota na fonte sobre os juros a um patamar de $1 \%$, remanescerá ao contribuinte o direito ao crédito francês de $20 \%^{415}$. No entanto, conforme decidido pela Corte francesa, diante da exoneração total do imposto no Brasil, não haveria mais que se falar em direito ao matching credit na França.

Assim, conclui-se que o entendimento do Conseil d'État, ao negar ao Banco Natexis o aproveitamento do matching credit previsto no Acordo Brasil-França, agiu não somente em desacordo com o texto do artigo XXII(2)(d), que não traz nenhuma restrição ao direito em questão quando não há tributação nenhuma no Estado da fonte, mas também em sentido contrário ao objetivo e à finalidade da cláusula de matching credit, que não são de evitar a dupla tributação (ou dupla não tributação) internacional, mas de fomentar os investimentos em países em desenvolvimento, como já mencionado no primeiro capítulo.

\subsection{Análise das cláusulas recíprocas de matching credit previstas nos acordos de bitributação celebrados pelo Brasil}

Além das cláusulas de matching credit unilaterais, em que apenas um Estado se vê obrigado a conceder, como crédito, um montante desvinculado do imposto efetivamente pago no Estado da fonte, há acordos de bitributação em que estão previstas cláusulas nas quais os dois Estados contratantes, reciprocamente, são obrigados a conceder crédito do imposto previamente estabelecido no acordo, desde que se encontrem na posição de Estado da residência.

${ }^{415}$ Cf. Guy Guest, op. cit. (nota 105), p. 2.133. 
De um modo geral, cláusulas de matching credit mútuas ou recíprocas estão previstas em acordos de bitributação celebrados entre o Brasil e outros países em desenvolvimento, uma vez que o fluxo de rendimentos, em tais relações, tende a ser equilibrado. É o caso dos acordos com a Coreia do Sul, Equador, Filipinas e Índia.

Contudo, duas exceções chamam a atenção nesse quadro: Espanha e Itália, Estados membros da OCDE e países ditos desenvolvidos (a despeito da grave crise econômica que sobre eles recai atualmente), também firmaram cláusulas de matching credit mútuas em seus acordos de bitributação com o Brasil.

É possível afirmar que tais cláusulas constituem um importante passo para o reconhecimento de que as cláusulas de matching credit, assim como as de tax sparing, não decorrem necessariamente de um auxílio aos países em desenvolvimento, concedido por partes dos países desenvolvidos.

\subsubsection{Acordo Brasil-Espanha}

No Acordo Brasil-Espanha ${ }^{416}$ encontra-se exemplo de cláusula de matching credit recíproca em um acordo celebrado entre o Brasil e um Estado membro da OCDE.

Determina o artigo $23^{417}$ do Acordo Brasil-Espanha que, para fins de concessão do crédito pelo Estado da residência (Brasil ou Espanha), considerar-se-á que os juros e

\footnotetext{
${ }^{416}$ Acordo para Evitar a Dupla Tributação e Prevenir a Evasão Fiscal em Matéria de Impostos Sobre a Renda, firmado entre a República Federativa do Brasil e o Estado Espanhol, em Brasília, a 14 de novembro de 1974. Aprovado pelo Decreto Legislativo $n^{\circ} 62 / 75$ e promulgado pelo Decreto $n^{\circ} 76.975 / 76$.

417 “ARTIGO 23 - Métodos para eliminar a dupla tributação

1. Quando um residente de um Estado Contratante receber rendimentos que, de acordo com as disposições da presente Convenção, sejam tributáveis no outro Estado Contratante, o primeiro Estado, ressalvado o disposto nos parágrafos 2, 3 e 4, permitirá que seja deduzido do imposto que cobrar sobre os rendimentos desse residente, um montante igual ao imposto sobre a renda pago no outro Estado Contratante.

Todavia, o montante deduzido não poderá exceder a fração do imposto sobre a renda, calculado antes da dedução, correspondente aos rendimentos tributáveis no outro Estado Contratante.

O disposto neste parágrafo se aplica, na Espanha, tanto aos impostos gerais como aos impostos a conta .

2. Para a dedução mencionada no parágrafo 1 , o imposto sobre os juros e "royalties" será sempre considerado como tendo sido pago com as alíquotas de $20 \%$ e $25 \%$ respectivamente .

3. Quando um residente da Espanha receber dividendos que, de acordo com as disposições da presente Convenção, sejam tributáveis no Brasil, a Espanha isentará de imposto estes dividendos, podendo no entanto ao calcular o imposto incidente sobre os rendimentos restantes desse residente, aplicar a alíquota que teria sido aplicável se tais dividendos não houvessem sido isentos .
} 
royalties terão sido tributados no Estado da fonte (Brasil ou Espanha) a alíquotas de, respectivamente, $20 \%$ e $25 \%$.

Interessante notar que o parágrafo $2^{\circ}$ do artigo 23 do Acordo Brasil-Espanha, diferentemente de outros acordos de bitributação brasileiros, não determina de maneira expressa se o cálculo do matching credit deve partir do montante bruto ou do montante líquido dos rendimentos considerados.

Tal discussão foi levada a juízo na Espanha, haja vista que determinada empresa espanhola, que havia calculado o matching credit de $20 \%$ sobre o montante bruto dos juros auferidos em decorrência de empréstimo efetuado a empresa brasileira, acabou por ser autuada, por entenderem as autoridades fiscais da Espanha que o matching credit deveria ser computado sobre os rendimentos líquidos.

Após o trâmite em sede administrativa e judicial, a lide, julgada em 27 de junho de 2012 pelo Tribunal Supremo da Espanha, que decidiu que, ao contrário do procedimento adotado pelo contribuinte, o matching credit deveria ser calculado sobre os lucros finais da empresa espanhola em relação aos juros recebidos, i.e., sobre o montante líquido dos juros $^{418}$.

Não nos parece que o entendimento adotado pela Corte espanhola seja o mais adequado. Isso porque, a despeito de não estar expresso no texto do acordo que o matching credit deverá ser calculado sobre os rendimentos brutos, o certo é que os juros são tributados, na sistemática do próprio acordo, com base nos rendimentos brutos auferidos. Efetivamente, não se cogita, na tributação dos juros pelo Estado da fonte, dos custos e despesas incorridos pelo contribuinte para auferi-los.

Destarte, em sua decisão, o Tribunal Supremo da Espanha acabou por restringir, indevidamente, o direito ao matching credit, de maneira manifestamente contrária à sistemática de tributação estabelecida pelo Acordo Brasil-Espanha para os juros - a qual, repita-se, considera os rendimentos brutos, e nunca os rendimentos líquidos.

4. Quando um residente do Brasil receber dividendos que de acordo com as disposições da presente Convenção sejam tributáveis na Espanha, o Brasil isentará de imposto esses dividendos."

418 "CENDOJ. Tribunal Supremo. Sala de lo Contencioso S. 7 de junio de 2012. Impuesto sobre sociedades, ejercicio de 1993. Doble deducción internacional. Art ${ }^{\circ} 23$ CDI con Brasil. El cálculo para determinar la base sobre la que hacerse la deducción es la de los ingresos realmente gravados. Sistema de Crédito equivalente o Matching Credit. Procede aplicar el 20\% de deducción sobre los rendimientos realmente obtenidos por los intereses de préstamo a entidad brasileña." 


\subsubsection{Acordo Brasil-Índia}

Tal como já mencionado, a Índia figura, ao lado do Brasil, como um dos países mais empenhados na defesa das cláusulas de tax sparing e matching credit. É natural, portanto, que haja disposição dessa natureza no Acordo Brasil-Índia ${ }^{419}$.

Com efeito, o artigo $23^{420}$ do Acordo Brasil-Índia, em seu parágrafo $2^{\circ}$, estabelece matching credit recíproco correspondente a $25 \%$ do montante bruto dos juros e dos royalties (que não os provenientes do uso ou da concessão do uso de marcas de indústria ou comércio) remetidos de um Estado contratante a outro.

Note-se que o dispositivo em tela é expresso ao esclarecer que o matching credit não poderá exceder o imposto devido no Estado da residência sobre esses mesmos rendimentos.

\footnotetext{
${ }^{419}$ Acordo para Evitar a Dupla Tributação e Prevenir a Evasão Fiscal em Matéria de Imposto sobre a Renda, firmado entre o Governo da República Federativa do Brasil e o Governo da República da Índia, em Nova Déli, a 26 de abril de 1988. Aprovado pelo Decreto Legislativo ${ }^{\circ}$ 214/91 e promulgado pelo Decreto ${ }^{\circ}$ $510 / 92$.

420 "ARTIGO 23 -_Métodos para eliminar a dupla tributação

1. Ressalvado o disposto nos parágrafos 3 e 4, quando um residente de um Estado Contratante receber rendimentos que, de acordo com as disposições da presente Convenção, sejam tributáveis no outro Estado Contratante, o primeiro Estado mencionado permitirá que seja deduzido do imposto incidente sobre os rendimentos desse residente um montante igual ao imposto pago no outro Estado.

Todavia, o montante deduzido não poderá exceder a fração do imposto, calculado antes da dedução, correspondente aos rendimentos que podem ser tributados no outro Estado.

2. Para a dedução mencionada no parágrafo 1, o imposto pago nesse outro Estado será sempre considerado como tendo sido pago à alíquota de $25 \%$ do montante bruto dos juros referidos no parágrafo 2 do Artigo $11 \mathrm{e}$ dos "royalties" referidos no parágrafo $2 \mathrm{~b}$ do Artigo 12 , desde que, no entanto, o imposto assim considerado como tendo sido pago não exceder o imposto exigível sobre esses rendimentos no primeiro Estado mencionado.

3. Quando uma sociedade residente de um Estado Contratante receber dividendos que, de acordo com o disposto no parágrafo 2 do Artigo 10, são tributáveis no outro Estado contratante, o primeiro Estado mencionado isentará de imposto esses dividendos.

4. Quando um residente da Índia auferir lucros que, de acordo com o disposto no parágrafo 5 do Artigo 10, sejam tributáveis no Brasil, a Índia isentará de imposto esses lucros."
} 


\subsubsection{Acordo Brasil-Itália}

No Acordo Brasil-Itália ${ }^{421}$, assim como no já mencionado Acordo Brasil-Espanha, verifica-se a existência de cláusula de matching credit mútua ou recíproca ${ }^{422}$, não obstante se esteja diante de um acordo de bitributação celebrado pelo Brasil com um Estado membro da OCDE.

$\mathrm{Na}$ realidade, embora o referido mecanismo do Acordo Brasil-Itália refira-se tanto aos fluxos de rendimentos do Brasil para a Itália quanto àqueles da Itália para o Brasil, pode-se dizer que a cláusula de matching credit relativa aos rendimentos auferidos na Itália e remetidos a residente no Brasil é menos ampla do que a cláusula inversa.

Isso porque, com relação à Itália, o parágrafo $1^{\circ}$ do artigo $23^{423}$ prevê o matching credit de $25 \%$ do montante bruto dos dividendos pagos a residentes no Brasil, apenas, não havendo disposições semelhantes no que se refere aos juros e royalties.

${ }^{421}$ Acordo para Evitar a Dupla Tributação e Prevenir a Evasão Fiscal em Matéria de Impostos sobre a Renda, celebrado entre o Governo da República Federativa do Brasil e o Governo da República Italiana, em Roma, a 3 de outubro de 1978. Aprovado pelo Decreto Legislativo $\mathrm{n}^{\circ}$ 77/79 e promulgado pelo Decreto $\mathrm{n}^{\circ}$ 85.985/81.

${ }^{422}$ Além do acordo de bitributação com o Brasil, a Itália também celebrou acordos com outros países em que as cláusulas de tax sparing e matching credit são aplicadas mutuamente para os dois Estados contratantes. É o caso, por exemplo, do antigo Acordo Itália-Israel e do Acordo Itália-Índia. Cf. Aaron Yaron. "Israel's tax sparing provisions with developed countries". International Business Law. v. 5, 1977, p. 331; D. P. Sengupta, op. cit. (nota 356), p. 592.

423 “ARTIGO 23 - Métodos para eliminar a dupla tributação

1. Quando um residente do Brasil receber rendimentos que, de acordo com as disposições da presente Convenção, sejam tributáveis na Itália, o Brasil permitirá que seja deduzido do imposto que cobrar sobre os rendimentos dessa pessoa um montante igual ao imposto sobre a renda pago na Itália."

Todavia, o montante deduzido não poderá exceder à fração do Imposto sobre a renda, calculado antes da dedução, correspondente aos rendimentos tributáveis na Itália.

Para a dedução acima indicada, o imposto italiano será sempre considerado como tendo sido pago à alíquota de 25 por cento do montante bruto dos dividendos pagos a um residente do Brasil.

2. Se um residente da Itália receber rendimentos derivados no Brasil, a Itália poderá, na determinação dos seus impostos sobre a renda especificados no Artigo 2 da presente Convenção, incluir os referidos rendimentos na base de cálculo de tais impostos, a não ser que disposições específicas da presente Convenção estipulem de outro modo.

Nesse caso, a Itália deduzirá, dos impostos assim calculados, o imposto sobre a renda pago no Brasil, mas em um montante que não exceda a proporção do mencionado imposto italiano correspondente à participação desses rendimentos no total dos rendimentos.

Ao contrário, nenhuma dedução será concedida se os rendimentos estiverem sujeitos na Itália, por solicitação do beneficiário dos referidos rendimentos, a um imposto definitivo retido na fonte.

3. Quando uma sociedade residente da Itália detiver pelo menos 25 por cento do capital de um sociedade residente do Brasil, a Itália isentará de imposto os dividendos recebidos pela sociedade residente da Itália da sociedade residente do Brasil. 
De outra parte, quando se trata de rendimentos auferidos no Brasil por residentes na Itália, o matching credit refere-se aos dividendos, juros e royalties. Assim é que, nos termos do parágrafo $4^{\circ}$ do artigo 23 do Acordo Brasil-Itália, para fins de eliminação da bitributação considera-se o imposto brasileiro como tendo sido pago à alíquota de $25 \%$ do montante bruto dos dividendos, juros e royalties.

O matching credit em comento não se aplica aos dividendos distribuídos por uma sociedade residente no Brasil a uma sociedade residente da Itália que detenha pelo menos 25\% do capital da primeira. Nessa hipótese, tais dividendos serão isentos na Itália, como disposto no parágrafo $3^{\circ}$ do artigo 23 do Acordo Brasil-Itália.

4. Para a dedução mencionada no parágrafo 2 do presente Artigo, o imposto brasileiro será sempre considerado como tendo sido pago à alíquota de 25 por cento do montante bruto:

a) dos dividendos, como definidos no parágrafo 4 do Artigo 10;

b) dos juros, como definidos no parágrafo 4 do Artigo 11; e

c) dos royalties, como definidos no parágrafo 4 do Artigo 12." 


\section{CLÁUSULAS DE TAX SPARING E MATCHING CREDIT: INDEVIDO AUXÍLIO AOS PAÍSES EM DESENVOLVIMENTO OU RECONHECIMENTO DA COMPETÊNCIA DO ESTADO DA FONTE?}

\subsection{A visão tradicional a respeito das cláusulas de tax sparing e matching credit}

Conforme pontuado ao longo do presente trabalho, o tax sparing (bem como o matching credit) é normalmente visto como uma concessão do Estado da residência em favor do Estado da fonte ${ }^{424}$, como meio de fomentar os investimentos estrangeiros neste último e, desta forma, ajudar a promover seu desenvolvimento econômico.

Esta concepção a respeito das cláusulas de tax sparing e matching credit parece ser uma das grandes responsáveis pela atual descrença e relutância dos países desenvolvidos, no bojo da própria OCDE, a respeito da inclusão destas cláusulas em acordos de bitributação.

Isso porque os países em desenvolvimento de outrora seriam, hoje, mais prósperos do que muitos Estados membros da OCDE. Se as cláusulas de tax sparing e matching credit são mecanismos de ajuda, por que razão deverão os países desenvolvidos prosseguir auxiliando países que se encontram em estágios mais avançados de desenvolvimento econômico?

Deve-se pontuar, nesse primeiro momento, que não se concorda com o entendimento de que os países em desenvolvimento, como é o caso do Brasil, ou mesmo da Índia, encontram-se em tal estágio econômico que não mais dependam da atração de investimentos estrangeiros.

Além do mais, conforme apontado no presente trabalho, há ainda um grande caminho a ser percorrido pelos países em desenvolvimento a fim de que alcancem indicadores sociais minimamente parecidos com os de países desenvolvidos.

${ }^{424}$ Cf. Hope Ashiabor, op. cit. (nota 41), p. 75. 
Não obstante tais considerações a respeito das economias dos países em desenvolvimento, é necessário que se tenha em conta que a visão meramente paternalista das cláusulas de tax sparing e matching credit deve ser revisitada, por não corresponder à integralidade das características de que estas se revestem.

\subsection{Uma nova visão para as cláusulas de tax sparing e matching credit}

Com efeito, ao lado da visão de que tax sparing e matching credit são mecanismos de auxílio aos países em desenvolvimento, já se encontrava também o entendimento de que tais dispositivos eram necessários para que se respeitasse a soberania do Estado da fonte.

Nesse passo, afirma-se que a Alemanha, por exemplo, tinha como política adotar cláusulas do gênero em seus acordos de bitributação com países em desenvolvimento, não somente pelo argumento de que os investimentos alemães em tais países deveriam ser incentivados (ou, ao menos, não desencorajados), mas também em respeito à soberania do Estado da fonte e às suas políticas fiscais ${ }^{425}$.

De fato, ao tratar do tax sparing, Klaus Vogel afirma que, do ponto de vista do direito tributário internacional, tal mecanismo conduziria ao mesmo resultado que seria obtido pela concessão de subsídio direto ao investidor estrangeiro pelo Estado da fonte, não tributado pelo Estado da residência ${ }^{426}$.

Tem-se, assim, que a concessão de um subsídio direto pelo Estado da fonte a um investidor estrangeiro seria integralmente respeitada pelo Estado da residência. Por que razão, então, seria justificável que, pela aplicação de um acordo de bitributação sem cláusulas de tax sparing ou matching credit, o incentivo fiscal acabasse por ser transferido ao Estado da residência, em vez de beneficiar o investidor estrangeiro?

Uma relevante característica do tax sparing e do matching credit que se deve destacar consiste no fato de que, nas hipóteses em que este mecanismo é adotado, o Estado da residência nada perde em termos de receitas tributárias, mas apenas deixa de auferir

\footnotetext{
${ }^{425}$ Cf. Harry A. Shannon III, op. cit. (nota 44), p. 89.

${ }^{426}$ Cf. Klaus Vogel, op. cit. (nota 103), p. 1.256.
} 
receitas que, a princípio, não lhe eram destinadas, mas sim ao investidor que aportou recursos nos países em desenvolvimento.

Nesse passo, cumpre apontar a interessante visão de Harry A. Shannon III a respeito do assunto. Como bem pontua o autor, quando o Estado da fonte concede um incentivo fiscal a um investidor não residente, está desistindo de cobrar receitas tributárias que, de outra forma, lhe seriam devidas ${ }^{427}$.

Em outros termos, ao conceder um incentivo fiscal, o Estado da fonte está despendendo recursos próprios para fomentar o investimento estrangeiro, tal como se recolhesse o tributo em sua integralidade e cedesse ao investidor estrangeiro, na forma de subsídio direto, parte do valor recolhido, em montante equivalente ao do benefício fiscal concedido $^{428}$. Nessa hipótese, em princípio, o investidor estrangeiro teria direito a um crédito integral no Estado da residência, a ser compensado com o imposto ali devido, muito embora se deva ponderar que algumas legislações internas apenas permitem o crédito de imposto pago no exterior que não seja de alguma maneira restituível.

Na ausência de cláusula de tax sparing, o incentivo fiscal será transferido ao Estado da residência, que ao mesmo tempo estará negando a política fiscal do Estado da fonte e recebendo uma receita eventual (windfall revenue), a que, em princípio, não teria direito ${ }^{429}$.

Nesse contexto, o papel do tax sparing seria o de eliminar esse ganho eventual recebido pelo Estado da residência, de modo a corrigir uma anomalia advinda da aplicação do método do crédito, não podendo, assim, ser entendido como um subsídio concedido pelo Estado da residência.

Fixadas estas premissas, cumpre mencionar que Harry A. Shannon III defende que o incentivo fiscal concedido pelo Estado da fonte constitui renda para o investidor estrangeiro, na medida em que se trata de um ganho que é acrescido ao seu patrimônio ${ }^{430}$.

Assim, o autor propõe um modelo que concilia a concessão do tax sparing pelo Estado da residência, aliada à tributação, também pelo Estado da residência, do benefício

\footnotetext{
${ }^{427}$ Cf. Harry A. Shannon III, op. cit. (nota 44), p. 90.

${ }^{428}$ Cf. Harry A. Shannon III, op. cit. (nota 44), p. 90.

${ }^{429}$ Cf. Harry A. Shannon III, op. cit. (nota 44), p. 90.

${ }^{430}$ Cf. Harry A. Shannon III, op. cit. (nota 44), p. 90.
} 
econômico auferido pelo investidor em razão do incentivo físcal conferido pelo Estado da fonte, tal como ocorreria se este recebesse um subsídio direto ${ }^{431}$.

Do entendimento de Harry A. Shannon III, denota-se o relevante reconhecimento do mecanismo de tax sparing como uma ferramenta destinada a corrigir uma distorção, que será verificada sempre que o Estado da fonte (seja um país em desenvolvimento ou não), deixar de exercer, total ou parcialmente, a sua competência tributária, atribuída pelo próprio acordo de bitributação. Poderia o Estado da residência, no máximo, buscar gravar o benefício fiscal a ser fruído por seus investidores residentes, porém sem jamais tolhê-los do incentivo concedido pelo Estado da fonte.

Não há que se cogitar, nesse passo, de qualquer renúncia fiscal por um Estado da residência que conceda uma cláusula de tax sparing ou matching credit em determinado acordo de bitributação.

Com efeito, em razão da repartição de competências realizada pelos acordos de bitributação, a situação abrangida por tais cláusulas sequer seria passível de tributação pelo Estado da residência, sendo descabida a alegação de que haveria uma renúncia fiscal por parte do Estado da residência.

Nesse sentido, mencione-se o entendimento de Cristiane Coelho, que também questiona a premissa paternalista de que as cláusulas de tax sparing correspondem a uma forma de auxílio, por parte dos países desenvolvidos, aos países em desenvolvimento. Como afirma a autora, tal visão parece partir do pressuposto de que o direito de tributar pertence, por natureza ou por lógica, ao Estado da residência, sendo este o único Estado qualificado a ditar as diretrizes tributárias a serem seguidas por seus residentes ${ }^{432}$.

Com efeito, o Estado da fonte é soberano, podendo determinar que fatos serão tributáveis pela sua legislação interna, assim como aqueles que não o serão. Na ausência de cláusulas de tax sparing e matching credit, essa possibilidade de escolha acaba por ser transferida, de forma indevida, ao Estado da residência, que vê sua tributação "residual" ser aumentada, sobremaneira, em virtude de reduções na tributação promovidas pelo Estado da fonte.

\footnotetext{
${ }^{431}$ Cf. Harry A. Shannon III, op. cit. (nota 44), pp. 90-91.

${ }^{432}$ Cf. Cristiane Coelho, op. cit. (nota 73), pp. 688-689.
} 
Portanto, mais do que mera transferência de um eventual incentivo fiscal destinado ao investidor estrangeiro, a ausência de cláusulas de tax sparing ou matching credit implica a transferência da própria competência tributária do Estado da fonte para o Estado da residência, em desacordo com a repartição de competências estabelecidas pelo acordo de bitributação. Trata-se, assim, de claro desrespeito às políticas fiscais do Estado da fonte, na medida em que sua soberania não é reconhecida pelo Estado da residência ${ }^{433}$. Nesse passo, a isenção (parcial ou total) nada mais é do que uma forma de exercer a competência tributária $^{434}$.

Concluímos com Luís Eduardo Schoueri, no sentido de que as cláusulas de tax sparing e matching credit não devem ser entendidas como favores concedidos pelos Estados da residência, mas simplesmente uma forma de tais Estados confirmarem que não têm direitos sobre rendimentos cuja tributação foi atribuída, nos termos do acordo de bitributação, ao Estado da fonte ${ }^{435}$.

\subsection{Perspectivas para o futuro das cláusulas de tax sparing e matching credit}

De qualquer forma, não nos parece que, em um futuro próximo, seja possível incutir nos países desenvolvidos a ideia de que o tax sparing e o matching credit apenas corrigem alocações de competências que, de outra forma, restariam distorcidas. Isso porque a visão da OCDE, contrária a tais cláusulas, vem encontrando grande acolhida entre seus Estados membros, conforme mencionado no capítulo 3.

Como resultado, o cenário que se descortina é o de impasses intermináveis em todas as negociações de acordos de bitributação que envolvam cláusulas de tax sparing e matching credit: de um lado, os países desenvolvidos recusando tais mecanismos, sob a alegação de que se trata de auxílio indevido; de outro, os países em desenvolvimento, defendendo tratar-se de reconhecimento de sua competência tributária. Em cenário ainda menos animador, os países em desenvolvimento simplesmente deixariam de clamar por tais cláusulas, institucionalizando ainda mais o desrespeito às repartições de competências

\footnotetext{
${ }^{433}$ Cf. Yong Suk Oh, op. cit. (nota 280), p. 60.

${ }^{434}$ Cf. Luís Eduardo Schoueri, op. cit. (nota 40), p. 106.

${ }^{435}$ Cf. Luís Eduardo Schoueri, op. cit. (nota 40), p. 106.
} 
fixadas pelos acordos de bitributação. Impende, assim, que sejam imaginadas soluções possíveis para tais conflitos.

Nesse sentido, mencione-se o entendimento de Pasquale Pistone, para quem o alívio da dupla tributação internacional deve estar alinhado ao objetivo de não interferência nas políticas fiscais dos países em desenvolvimento. Tendo em vista tal propósito, o autor sugere que o método do crédito seja substituído pelo tax sparing, pelo matching credit ou pela isenção ${ }^{436}$.

No mesmo passo, Luís Eduardo Schoueri, ao tratar da política brasileira de negociação de acordos de bitributação no que diz respeito às cláusulas de tax sparing e matching credit, defendeu ser a aplicação do método da isenção uma solução possível para o impasse verificado entre países desenvolvidos e países em desenvolvimento ${ }^{437}$.

De fato, sendo a isenção um método para eliminar a bitributação expressamente previsto na Convenção Modelo da OCDE, parece-nos que sua adoção poderá gerar menos objeções dos países desenvolvidos e da própria Organização, e representar, no mesmo passo, um efetivo respeito às atribuições de competências tributárias definidas nos acordos de bitributação.

\footnotetext{
${ }^{436}$ Cf. Pasquale Pistone. "Tax treaties with developing countries: a plea for new allocation rules and a combined legal and economic approach". TORRES, Heleno Taveira (coord.). Direito Tributário Internacional Aplicado. v. VI. São Paulo: Quartier Latin, 2011, p. 122.

${ }^{437}$ Cf. Luís Eduardo Schoueri, op. cit. (nota 75), p. 283.
} 


\section{CONSIDERAÇÕES FINAIS}

Pretendeu-se, com o presente trabalho, oferecer subsídios para um enfrentamento das questões relacionadas às cláusulas de tax sparing e matching credit, considerando-se, sobretudo, a política atualmente adotada pela OCDE e por diversos países, em especial Brasil e Estados Unidos, no que concerne a tais mecanismos.

Pretendeu-se demonstrar, ao longo do presente trabalho, que as objeções ao tax sparing apresentadas pela OCDE não são suficientemente bem fundamentadas, de forma a justificar uma reconsideração do tax sparing e do matching credit, como pretende tal Organização.

Não obstante, analisando-se o hodierno posicionamento dos países desenvolvidos a respeito do assunto, nota-se uma crescente relutância na concessão de cláusulas de tax sparing e matching credit, possivelmente motivada pelo apelo da OCDE, o que vem sendo sentido pelo Brasil. Com efeito, a denúncia do Acordo Brasil-Alemanha e a ausência de um acordo com os Estados Unidos até os dias de hoje são comprovações de tal assertiva.

É possível que as dificuldades atualmente enfrentadas possam ser resolvidas de maneira adequada caso se adote o entendimento de que as cláusulas de tax sparing e matching credit não servem ao único e exclusivo propósito de auxiliar o crescimento de países em desenvolvimento, haja vista que decorrem da própria repartição de competências atribuída pelos acordos de bitributação.

No entanto, a alteração do atual posicionamento dos países desenvolvidos, aparentemente, será tarefa árdua, considerando-se os já consolidados argumentos contrários ao tax sparing, que são exaustivamente repetidos por parte da doutrina estrangeira.

Assim, conclui-se mencionando a adoção do método da isenção, critério expressamente previsto na Convenção Modelo da OCDE, como uma alternativa ao tax sparing e ao matching credit a ser analisada, a qual possivelmente encontraria menor resistência, por não estar atrelada a ideias de auxílio indevido a países que não mais precisam de ajuda para fomentar seu desenvolvimento econômico. 


\section{BIBLIOGRAFIA}

AMICO, Joseph A.. "Brazil: Developing and implementing tax treaty policy: the tax sparing clause". Bulletin for International Taxation. agosto/setembro, 1989, pp. 408-411.

ASHIABOR, Hope. "Tax sparing: a timeworn mechanism in Australia's bilateral tax treaties with its trading partners in Southeast Asia?". The International Tax Journal. v. 24, 1998, pp. 67-98.

AVI-YONAH, Reuven S.. "Globalization and tax competition: implications for developing countries". TANZI, Vito; BARREIX, Alberto; VILLELA, Luiz (editores). Taxation and Latin American Integration. Washington: Inter-American Development Bank; Cambridge: David Rockefeller Center for Latin American Studies Harvard University, 2008, pp. 173193.

AZÉMAR, Céline; DELIOS, Andrew. "Tax competition and FDI: the special case of developing countries". Journal of Japanese and International Economies. v. 22, 2008, pp. 85-108.

AZÉMAR, Céline; DESBORDES, Rodolphe; MUCCHIELLI, Jean-Louis. "Do tax sparing agreements contribute to the attraction of FDI in developing countries?". International Tax and Public Finance. v. 14, n. 5, 2007, pp. 543-562.

BAIN, Kathrin; KREVER, Richard; O'CONNOR, Amanda. “Australia”. LANG, Michael; PISTONE, Pasquale; SCHUCH, Josef; STARINGER, Claus (editores). The impact of the OECD and the UN Model Conventions on bilateral tax treaties. Cambridge: Cambridge University, 2012, pp. 68-109.

BARKER, William B.. “An international tax system for emerging economies, tax sparing, and development: it is all about source!". University of Pennsylvania Journal of International Law. v. 29, n. 2, 2007, pp. 349-389.

BELLAN, Daniel Vitor. Direito tributário internacional: rendimentos de pessoas físicas nos tratados internacionais contra a dupla tributação. São Paulo: Saraiva, 2010. 
BENDER, Tanja; BURGERS, Irene; PETERS, Faustina. "The Netherlands". LANG, Michael; PISTONE, Pasquale; SCHUCH, Josef; STARINGER, Claus (editores). The impact of the OECD and the UN Model Conventions on bilateral tax treaties. Cambridge: Cambridge University, 2012, pp. 666-734.

BERGLUND, Martin. “Sweden”. LANG, Michael; PISTONE, Pasquale; SCHUCH, Josef; STARINGER, Claus (editores). The impact of the OECD and the UN Model Conventions on bilateral tax treaties. Cambridge: Cambridge University, 2012, pp. 1.056-1.082.

BIGER, Nahum; PEPE, Michael F. G.. "The inhibiting effect of bilateral tax treaties on domestic tax incentives". Canadian Public Policy / Analyse de Politiques. v. 12, n. 3, setembro, 1986, pp. 424-431.

BOIDMAN, Nathan. "Canada: some current issues with treaty tax-sparing provisions". Bulletin for International Taxation. agosto/setembro, 1985, pp. 387-391.

BRAUNER, Yariv. "Por que os Estados Unidos firmam tratados tributários? E por que não têm tratado tributário com o Brasil?”. Tradução de Célia Korn. OLIVEIRA, Ricardo Mariz de; SCHOUERI, Luís Eduardo; ZILVETI, Fernando Aurelio. Revista Direito Tributário Atual. v. 26. São Paulo: Instituto Brasileiro de Direito Tributário: Dialética, 2011, pp. 109128.

BROOKS, Kim. "Tax sparing: a needed incentive for foreign investment in low-income countries or an unnecessary revenue sacrifice?". Queen's Law Journal. v. 34, 2009, pp. 505-564.

BROWN, Catherine; O’BRIEN, Martha. "Canada". LANG, Michael; PISTONE, Pasquale; SCHUCH, Josef; STARINGER, Claus (editores). The impact of the OECD and the UN Model Conventions on bilateral tax treaties. Cambridge: Cambridge University, 2012, pp. 203-231.

CABRAL, Flávio Garcia. "Interpretação e aplicação dos tratados contra a pluritributação internacional". Revista Tributária e de Finanças Públicas. v. 105, ano 20, julho/agosto, 2012, pp. 79-107. 
CHOI, Sung Keun. “Korea, Republic of”. Cahiers de Droit Fiscal International. Practical issues in the application of double tax conventions. v. LXXXIIIb. The Hague: Kluwer Law International, 1998, pp. 447-490.

CHRISTIANS, Allison D.. "Tax treaties for investment and aid to Sub-Saharan Africa: a case study". Brooklyn Law Review. v. 71, n. 2, 2005, pp. 639-713.

CLEAVE, Brian. "The UK”. LANG, Michael; PISTONE, Pasquale; SCHUCH, Josef; STARINGER, Claus (editores). The impact of the OECD and the UN Model Conventions on bilateral tax treaties. Cambridge: Cambridge University, 2012, pp. 1.101-1.148.

COELHO, Cristiane. "Interpretação dos tratados internacionais em matéria tributária: doutrina e prática na América Latina". TORRES, Heleno Taveira (coord.). Direito Tributário e Ordem Econômica: Homenagem aos 60 anos da ABDF. São Paulo: Quartier Latin, 2010, pp. 691-711.

. “Tax sparing and Brazil's tax treaties”. Tax Notes International. v.

51, n. 8, agosto, 2008, pp. 685-697.

CRUZ, Natalia Quiñones. "Colombia”. LANG, Michael; PISTONE, Pasquale; SCHUCH, Josef; STARINGER, Claus (editores). The impact of the OECD and the UN Model Conventions on bilateral tax treaties. Cambridge: Cambridge University, 2012, pp. 294310.

CUI, Wei. "China”. LANG, Michael; PISTONE, Pasquale; SCHUCH, Josef; STARINGER, Claus (editores). The impact of the OECD and the UN Model Conventions on bilateral tax treaties. Cambridge: Cambridge University, 2012, pp. 261-293.

DARCY, John. "The effect of tax-sparing on United States business in China". University of San Francisco Law Review. v. 21, 1987, pp. 393-417.

DORNELLES, Francisco Oswaldo Neves. “Acordo Brasil / Ucrânia para Eliminar a Dupla Tributação da Renda". Discurso proferido pelo Deputado FRANCISCO DORNELLES (PP/RJ), na Sessão da Câmara dos Deputados de 27 de novembro de 2003. Disponível em: <http://migre.me/cUs2f>. Acesso em: 30 de setembro de 2012. 
“Acordo fiscal Brasil-EUA". Folha de S. Paulo. São Paulo, 28 de

outubro, 2007.2 Disponível em: $<$ http://www1.folha.uol.com.br/fsp/opiniao/fz2810200709.htm>. Acesso em: 20 de novembro de 2012.

• “Acordos para eliminar a Dupla Tributação". Revista de Direito Tributário. ano 2, n. 3, janeiro/março, 1978, pp. 251-257.

EASSON, Alexander J.. "Tax incentives for foreign direct investment part II: design considerations". Bulletin for International Taxation. v. 55, n. 8, agosto, 2001, pp. 365-375. . "Tax incentives for foreign direct investment part I: recent trends and countertrends". Bulletin for International Taxation. v. 55, n. 7, julho, 2001, pp. 266274.

. "The evolution of Canada's tax treaty policy since the Royal Commission on Taxation”. Osgoode Hall Law Journal. v. 26, n. 3, 1988, pp. 495-536.

FINNERTY, Chris; MERKS, Paulus; PETRICCIONE, Mario; RUSSO, Raffaele. Fundamentals of international tax planning. Amsterdam: IBFD, 2007.

FURUSETH, Eivind. "Norway”. LANG, Michael; PISTONE, Pasquale; SCHUCH, Josef; STARINGER, Claus (editores). The impact of the OECD and the UN Model Conventions on bilateral tax treaties. Cambridge: Cambridge University, 2012, pp. 768-795.

GONZAGA, Livia Leite Baron. A interpretação das convenções contra dupla tributação internacional à luz da teoria da argumentação jurídica. Tese de doutorado. São Paulo: Universidade de São Paulo, 2010.

GUEST, Guest. «L'affaire des crédits d'impôt brésiliens, ou les limites de l'interprétation littérale des conventions ». Revue de Droit Fiscal. n. 50, dezembro, 2006, pp 2.124-2.133.

GUSTAFSON, Charles. “The USA”. LANG, Michael; PISTONE, Pasquale; SCHUCH, Josef; STARINGER, Claus (editores). The impact of the OECD and the UN Model Conventions on bilateral tax treaties. Cambridge: Cambridge University, 2012, pp. 1.1491.179 . 
HINES JR., James R.. “Tax sparing' and direct investment in developing countries”. NBER Working Paper No. 6728. Cambridge: National Bureau of Economic Research. setembro, 1998, pp. 1-47. Disponível em: <http://www.nber.org/papers/w6728>. Acesso em: 04 de novembro de 2012.

HOLLMAN, Lawrence D.. "Tax legislation affecting foreign operations - II: further proposals". The Tax Executive. v. 10, 1958, pp. 284-302.

INTERNATIONAL BUREAU OF FISCAL DOCUMENTATION. IBFD International Tax Glossary. 6. ed. Amsterdam: IBFD, 2009.

KELLEY, Patrick L.. "Tax treaties between United States and developing countries: the need for a new U.S. initiative”. The American Journal of International Law. v. 65, n. 1, janeiro, 1971, pp. 159-167.

KUST, Matthew J.. "Tax treaties with the underindustrialized countries". The Tax Executive. v. 13, 1961, pp. 175-191.

. “The Pakistan Tax Treaty”. The Tax Executive. v. 10, 1958, pp. 303-

313.

LAMPERT, Steffen. “Germany”. LANG, Michael; PISTONE, Pasquale; SCHUCH, Josef; STARINGER, Claus (editores). The impact of the OECD and the UN Model Conventions on bilateral tax treaties. Cambridge: Cambridge University, 2012, pp. 466-500.

LAUREY, Damian. "Reexamining U.S. tax sparing policy with developing countries: the merits of falling in line with international norms". Virginia Tax Review. v. 20, 2000, pp. 467-497.

LIEBMAN, Howard M.. "A formula for tax-sparing credits in U.S. tax treaties with developing countries". The American Journal of International Law. v. 72, n. 2, abril, 1978, pp. 296-316.

MARINHO, Anapaula Trindade; FERREIRA, Vanessa Arruda. "Crédito de imposto fictício: de uma noção nebulosa a um regime jurídico incerto". Revista de Direito Tributário Internacional. v. 11. São Paulo: Quartier Latin, 2009, pp. 9-48. 
MEIRELLES, Morvan. "Tax sparing credits in tax treaties: the future and the effect on EC law”. European Taxation. maio, 2009, pp. 263-273.

MITCHELL, Richard. "United States-Brazil bilateral income tax treaty negotiations". Hastings International \& Comparative Law Review. v. 21, 1997, pp. 209-239.

MONTES, José Madariaga; VILLANUEVA, Felipe Yáñez. "Chile”. LANG, Michael; PISTONE, Pasquale; SCHUCH, Josef; STARINGER, Claus (editores). The impact of the OECD and the UN Model Conventions on bilateral tax treaties. Cambridge: Cambridge University, 2012, pp. 232-260.

MUSGRAVE, Richard A.. "Criteria for foreign tax credit". Taxation and operations abroad. Princeton: Tax Institute, 1960, pp. 83-93.

OEPEN, Wolfgang. "A Alemanha denuncia seu tratado de dupla tributação com o Brasil razões e consequiências da denúncia do tratado sob um ponto de vista alemão". Revista de Direito Tributário Internacional. v. 1. São Paulo: Quartier Latin, 2005, pp. 209-226.

$\mathrm{OH}$, Yong Suk. "A critique of U.S. policy on the tax sparing credit, from the perspective of less developed countries". The Korean Journal of Comparative Law. v. 15, 1987, pp. 3866.

OLIVER, J. David B.. “Tax Sparing”. Intertax. v. 26, n. 6-7, 1998, pp. 190-191.

ORGANIZAÇÃO DAS NAÇÕES UNIDAS. Manual for the Negotiation of Bilateral Tax Treaties between Developed and Developing Countries. New York: UN, 2003.

ORGANIZAÇÃO PARA A COOPERAÇÃO E DESENVOLVIMENTO ECONÔMICO. Tax effects on Foreign Direct Investment: recent evidence and policy analysis. Paris: OECD, 2007. Tax sparing: a reconsideration. Paris: OCDE, 1998.

OWENS, Jeffrey; FENSBY, Torsten. "Is there a need to re-evaluate tax sparing?". Intertax. v. 26, n. 10, 1998, pp. 274-279.

PEREGIL, Francisco. “Argentina rompe su acuerdo fiscal con España que evitaba la doble imposición". El País. Buenos Aires, 14 de julho, 2012. Disponível em: 
<http://economia.elpais.com/economia/2012/07/14/actualidad/1342216880_042551.html>. Acesso em: 08 de setembro de 2012.

PISTONE, Pasquale. "General report”. LANG, Michael; PISTONE, Pasquale; SCHUCH, Josef; STARINGER, Claus (editores). The impact of the OECD and the UN Model Conventions on bilateral tax treaties. Cambridge: Cambridge University, 2012, pp. 1-36.

. "Tax treaties with developing countries: a plea for new allocation rules and a combined legal and economic approach". TORRES, Heleno Taveira (coord.). Direito Tributário Internacional Aplicado. v. VI. São Paulo: Quartier Latin, 2011, pp. 99125 .

PNUD - Programa das Nações Unidas para o Desenvolvimento. Relatório do Desenvolvimento Humano de 2011. Sustentabilidade e Equidade: Um Futuro Melhor para Todos. New York: PNUD. Disponível em: $<$ http://hdr.undp.org/en/media/HDR_2011_PT_Complete.pdf>. Acesso em: 15 de outubro de 2012.

PRATS, F. Alfredo García. "Spain”. LANG, Michael; PISTONE, Pasquale; SCHUCH, Josef; STARINGER, Claus (editores). The impact of the OECD and the UN Model Conventions on bilateral tax treaties. Cambridge: Cambridge University, 2012, pp. 1.0261.055 .

RATTO, Cecilia Delgado. "Peru". LANG, Michael; PISTONE, Pasquale; SCHUCH, Josef; STARINGER, Claus (editores). The impact of the OECD and the UN Model Conventions on bilateral tax treaties. Cambridge: Cambridge University, 2012, pp. 796819.

ROCHA, Sergio André. Interpretação dos tratados contra a bitributação da renda. Rio de Janeiro: Lumen Juris, 2008.

ROMERO, Jose Andrés. "Why Colombia should negotiate international tax treaties". Tax Notes International. v. 39, n. 4, julho, 2005, pp. 357-375.

ROSENBLOOM, H. David. "Trends in tax treaties between the United States and developing countries'. UN Draft Model Taxation Convention. Deventer: Kluwer, 1979, pp. 18-21. 
ROTHMANN, Gerd Willi. "A denúncia do Acordo de Bitributação Brasil-Alemanha e suas conseqüências”. ROCHA, Valdir de Oliveira (coord.). Grandes questões atuais do Direito Tributário. v. 9. São Paulo: Dialética, 2005, pp. 146-179.

. "Bitributação internacional” (verbete). FRANÇA, Rubens Limongi (coord.). Enciclopédia Saraiva do Direito. v. 11. São Paulo: Saraiva, 1977, pp. 447-461.

SACCHETTO, Claudio. "Política de tratados em matéria tributária para países emergentes vis-à-vis países desenvolvidos e em via de desenvolvimento". Tradução de Jonathan Barros Vita. COSTA, Alcides Jorge; SCHOUERI, Luís Eduardo; BONILHA, Paulo Celso Bergstrom (coords.). Direito Tributário Atual. v. 23. São Paulo: Dialética: IBDT, 2009, pp. 72-87.

SANTOS, João Victor Guedes; RODRIGUES, Flávia Cavalcanti Nogueira. “Compensação do imposto pago no exterior: a aplicabilidade de medidas unilaterais em casos de inobservância de limitações contidas em tratado". Revista de Direito Tributário Internacional. v. 10. São Paulo: Quartier Latin, 2009, pp. 85-107.

SCHÖN, Wolfgang. "International tax coordination for a second-best world (part I)". World Tax Journal. v. 1, outubro, 2009, pp. 67-114.

SCHOUERI, Luís Eduardo. "Acordos de bitributação e incentivos fiscais: o papel das cláusulas de tax sparing e matching credit". MARTINS, Ives Gandra da Silva; ELALI, André; PEIXOTO, Marcelo Magalhães (coords.). Incentivos fiscais: questões pontuais nas esferas federal, estadual e municipal. São Paulo: MP Editora, 2007, pp. 253-263.

. "Contribuição à história dos acordos de bitributação: a experiência brasileira". COSTA, Alcides Jorge; SCHOUERI, Luís Eduardo; BONILHA, Paulo Celso Bergstrom (coords.). Direito Tributário Atual. v. 22. São Paulo: Dialética: IBDT, 2008, pp. 267-287.

- "Princípios no Direito Tributário Internacional: territorialidade, fonte e universalidade". FERRAZ, Roberto (org.). Princípios e limites da tributação. São Paulo: Quartier Latin, 2005, pp. 321-374.

. "Tax sparing: uma reconsideração da reconsideração". OLIVEIRA, Ricardo Mariz de; SCHOUERI, Luís Eduardo; ZILVETI, Fernando Aurelio. Revista 
Direito Tributário Atual. v. 26. São Paulo: Instituto Brasileiro de Direito Tributário: Dialética, 2011, pp. 93-108.

. Normas Tributárias Indutoras e Intervenção Econômica. Rio de Janeiro: Forense, 2005.

Preços de Transferência no Direito Tributário Brasileiro. 2. ed. São

Paulo: Dialética, 2006.

SCHOUERI, Luís Eduardo; SILVA, Natalie Matos. "Brazil”. LANG, Michael; PISTONE, Pasquale; SCHUCH, Josef; STARINGER, Claus (editores). The impact of the OECD and the UN Model Conventions on bilateral tax treaties. Cambridge: Cambridge University, 2012, pp. 171-202.

SENGUPTA, D. P.. "India”. LANG, Michael; PISTONE, Pasquale; SCHUCH, Josef; STARINGER, Claus (editores). The impact of the OECD and the UN Model Conventions on bilateral tax treaties. Cambridge: Cambridge University, 2012, pp. 549-597.

SHANNON III, Harry A.. “Tax incentives and tax sparing”. Intertax. v. 2, fevereiro, 1992, pp. 84-96.

SILVA, Mauro José. Da competição à cooperação internacional: aspectos jurídicos da promoção ao desenvolvimento nacional num cenário internacionalizado. Tese de doutorado. São Paulo: Universidade de São Paulo, 2009.

SILVA, Natalie Matos. "O caso Société Natexis Banque Populaire e a cláusula de matching credit do Acordo de Bitributação entre Brasil e França”. OLIVEIRA, Ricardo Mariz de; SCHOUERI, Luís Eduardo; ZILVETI, Fernando Aurelio. Revista Direito Tributário Atual. v. 28. São Paulo: Instituto Brasileiro de Direito Tributário: Dialética, 2012, pp. 231-248.

SILVEIRA, Rodrigo Maitto da. Aplicação de tratados internacionais contra a bitributação - Qualificação de partnership joint ventures. Série Doutrina Tributária Vol. I. São Paulo: Quartier Latin, 2006. 
TAVOLARO, Agostinho Toffoli. "Tratado Brasil/EUA sobre tributação de renda e de capital". TORRES, Heleno Taveira (coord.). Direito Tributário e Ordem Econômica: Homenagem aos 60 anos da ABDF. São Paulo: Quartier Latin, 2010, pp. 747-772.

TAYLOR, Willard B.. "O que um acordo de bitributação entre Brasil e EUA poderia estipular?”. Tradução de Flávio Rubinstein. COSTA, Alcides Jorge; SCHOUERI, Luís Eduardo; BONILHA, Paulo Celso Bergstrom (coords.). Direito Tributário Atual. v. 21. São Paulo: Dialética: IBDT, 2007, pp. 151-157.

THOMPSON JR., Samuel C.. "The case for tax sparing along with expanding and limiting the Subpart F regime”. The George Washington International Law Review. v. 35, 2003, pp. 303-313.

THURONYI, Victor. "Recent treaty practice on tax sparing". Tax Notes International. v. 29, n. 3, janeiro, 2003, pp. 301-303.

TOAZE, Deborah. "Tax sparing: good intentions, unintended results". Canadian Tax Journal. v. 49, n. 4, 2001, pp. 879-924.

TORRES, Heleno Taveira. Pluritributação internacional sobre as rendas de empresas. 2. ed. São Paulo: Revista dos Tribunais, 2001.

UNITED STATES SENATE. Double Taxation Convention with Pakistan: Hearing Before the Senate Committee on Foreign Relations. $85^{\text {th }}$ Congress, $1^{\text {st }}$ Session. Washington: United States Government Printing Office, 1957, pp. 1-34.

VAISSIÈRE, Hugues Perdriel; BLÉTIÈRE, Emmanuel Raingeard de la. "France”. LANG, Michael; PISTONE, Pasquale; SCHUCH, Josef; STARINGER, Claus (editores). The impact of the OECD and the UN Model Conventions on bilateral tax treaties. Cambridge: Cambridge University, 2012, pp. 421-465.

VASCONCELLOS, Roberto França de. "Aspectos econômicos dos tratados internacionais em matéria tributária". Revista de Direito Tributário Internacional. v. 1. São Paulo: Quartier Latin, 2005, pp. 147-191.

VERSTRAETEN, Axel A.. “Argentina”. LANG, Michael; PISTONE, Pasquale; SCHUCH, Josef; STARINGER, Claus (editores). The impact of the OECD and the UN 
Model Conventions on bilateral tax treaties. Cambridge: Cambridge University, 2012, pp. 37-67.

VOGEL, Klaus. "Double tax treaties and their interpretation". International Tax \& Business Lawyer. v. 4, ano 1, 1986, pp. 1-85.

On double taxation conventions: a commentary to the OECD, UN, and US model conventions for the avoidance of double taxation on income and capital, with particular reference to German treaty practice. 3. ed. London: Kluwer Law International, 1997.

VOGEL, Klaus; PROKISCH, Rainier G.. "General report”. Cahiers de Droit Fiscal International. Interpretation of double taxation conventions. v. LXXVIIIa. Deventer: Kluwer Law and Taxation, 1993, pp. 55-85.

XAVIER, Alberto. Direito Tributário Internacional do Brasil. 6. ed. Rio de Janeiro: Forense, 2007.

YARON, Aaron. "Israel's tax sparing provisions with developed countries". International Business Law. v. 5, 1977, pp. 329-343. 